\title{
Determinants of sectoral average wage growth rates in a specific factors model with international capital movements: the case of Cobb-Douglas production functions
}

Citation for published version (APA):

van Loo, I., \& Ziesemer, T. H. W. (1998). Determinants of sectoral average wage growth rates in a specific factors model with international capital movements: the case of Cobb-Douglas production functions. MERIT, Maastricht Economic Research Institute on Innovation and Technology. MERIT Research Memoranda No. 006 https://doi.org/10.26481/umamer.1998006

Document status and date:

Published: 01/01/1998

DOI:

10.26481/umamer.1998006

Document Version:

Publisher's PDF, also known as Version of record

Please check the document version of this publication:

- A submitted manuscript is the version of the article upon submission and before peer-review. There can be important differences between the submitted version and the official published version of record. People interested in the research are advised to contact the author for the final version of the publication, or visit the DOI to the publisher's website.

- The final author version and the galley proof are versions of the publication after peer review.

- The final published version features the final layout of the paper including the volume, issue and page numbers.

Link to publication

\footnotetext{
General rights rights.

- You may freely distribute the URL identifying the publication in the public portal. please follow below link for the End User Agreement:

www.umlib.nl/taverne-license

Take down policy

If you believe that this document breaches copyright please contact us at:

repository@maastrichtuniversity.nl

providing details and we will investigate your claim.
}

Copyright and moral rights for the publications made accessible in the public portal are retained by the authors and/or other copyright owners and it is a condition of accessing publications that users recognise and abide by the legal requirements associated with these

- Users may download and print one copy of any publication from the public portal for the purpose of private study or research.

- You may not further distribute the material or use it for any profit-making activity or commercial gain

If the publication is distributed under the terms of Article 25fa of the Dutch Copyright Act, indicated by the "Taverne" license above, 


\title{
Determinants Of Sectoral Average Wage Growth Rates in a Specific Factors Model with International Capital Movements: The Case of Cobb-Douglas Production Functions ${ }^{1}$
}

\author{
Ivo De Loo, \\ MERIT, Maastricht University \\ Thomas Ziesemer, \\ Department of Economics and MERIT, Maastricht University
}

April 1998

\begin{abstract}
The cost-minimization part of a specific factors model with perfect capital movements and both perfect and imperfect competition is used here to explain the growth rate of wages as a function of technical change, terms of trade changes, interest rate changes and the growth rate of the labour supply. Our estimation of the perfect competition model for 67 combinations of countries and sectors yields the result that technical change explains a higher percentage of wage growth than changes in the terms of trade do before the 1980s. From the 1980s onwards international trade is slightly more influential than technical progress. Much more important than these two are changes in the sector specific labour supply in all countries but the UK. In the UK terms of trade changes matter most. However, since we cannot exclude increasing returns, a model with imperfect competition is also estimated. Besides a confirmation of the strong results for labour, evidence of increasing returns is found in especially the Netherlands and the US. Almost no evidence hereof is found in Germany and the UK. Finally we consider policy conclusions.
\end{abstract}

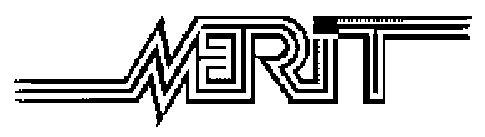

Maastricht Economic Research Institute on Innovation and Technology, University of Maastricht, P.O. Box 616, 6200 MD Maastricht, The Netherlands, tel: +31 43 3883867 / 3872, fax: +31 43 3216518, Email: i.deloo@merit.unimaas.nl and t.ziesemer@algec.unimaas.nl

1. The perfect competition part of this paper has been presented at the ESF conference 'Economic growth in closed and open economies', Lucca, September 1997, the TSER group seminar on technology and employment, Paris, October 1997 and the conference 'Unemployment in Europe', Maastricht, October 1997. We especially would like to thank Luc Soete, Huw Lloyd-Ellis, Giovanni Russo and Winfried Vogt for their comments. The usual disclaimer applies. A previous version of this paper appeared as MERIT Research Memorandum RM 98-001 but should not be quoted because of data errors. 


\section{Introduction}

Sectoral wages are the average of the wages for skilled and unskilled labour. Explaining their development has recently led to some controversies (see Freeman 1995). The major problems discussed are why do wages for skilled and unskilled labour diverge in the US and why has unemployment been heavily concentrated on low-skilled workers in Europe? These shifts can also be observed in Newly Industrialized Countries (NICs) (see Richardson 1995). The wage determination question, however, is of broader interest.

Many economists using closed or open economy growth models would explain wage growth mainly as a consequence of technical progress. Labour market economists would tend to emphasize (sectoral) supply and demand with little weight on international aspects (see Richardson 1995). Trade economists would tend to ignore the supply of labour when using the Stolper-Samuelson theorem. However, in a multisectoral world of international trade and capital movements it is tempting to take a broader perspective. Consequently, one may ask the question what the relative importance of the major determinants of (average) wage growth and employment -international trade or factor movements, technological change or labour market developments- are once one integrates all of them into one framework. In this paper we try to answer this question with regard to the US and six European countries (where wage inequality seemingly has changed much less than in the US). The inequality issue will not be addressed in this paper. We analyze average wages.

Lawrence and Slaughter (1993) and Krugman (1994) have argued that international trade would have an impact on wages, if any, via changes in the terms of trade. However, they indicated that the terms of trade of the US are almost unchanged and therefore changes in wages must be due to technical change. This argument leaves us with several open issues:

i) Results may be different for other countries than just the US;

ii) Results may change if we do not argue in terms of a two-sector model but at a more disaggregated level, because some of us will remember that in continental Europe the shipbuilding sector did shrink in the 1970s, automobile business was faced with increased competition from Japan in the early 1980s and the European consumer electronics sector lost grounds in the 1980s and 1990s. Ultimately, protectionists lobby at the sectoral or even firm level and not at the macro level; iii) Once international capital movements are taken into account, not only the terms of trade but also interest rates become an exogenous variable for a (model of a) country and their changes should have an impact on wage growth according to economic theory.

How did the literature treat these three issues? The only contribution on average wages so far is Lawrence and Slaughter (1993). Some other insights are gained from the wage inequality debate by:

i) Lücke (1997), who has looked at data for Germany and the UK and Oscarsson (1997) for Sweden. Seemingly, for many other countries this has not been done (within an international trade framework). Oliveira Martins (1994), using an 
industrial economics rather than an international trade approach also looks at several countries;

ii) Leamer (1996), who sees the point of relevance for single sectors too, mentioning apparel and textiles in the US. Krugman and Lawrence (1993) acknowledge that Japan did threaten US textiles in the 1960s and semiconductors in the 1990s;

iii) Leamer (1993), who takes international capital movements into account when making theoretical scenarios but not when running estimations. Wood (1994), as well as Sachs and Shatz (1994), also look at several sectors and international capital movements. However, they do not have an integrating framework but rather look at all aspects, separately running regressions that give some intuition on their idea that international trade, technology and international capital movements are all important. Thus, it seems to be worthwhile to investigate all of these points more closely.

Most of the wage inequality debate in international economics has been conducted in terms of Heckscher-Ohlin models (see Sachs and Shatz 1994, Baldwin and Cain 1997, Lücke 1997, Oscarsson 1997). Krugman and Obstfeld (1997) give a justification for this choice: although labour may not be mobile between sectors because its skills are specific to one sector only, reschooling could achieve the desired mobility after some time which would justify the mobility assumption of the Heckscher-Ohlin model. Against this we like to propose that before reschooling, labour is specific to one (or several) sector(s) and after reschooling it is specific to different sectors or just one. We prefer to capture this with a specific factors model that has an exogenously changing labour supply for each sector and allows for sectoral differences in wages, whereas the HO model does not (see Leamer 1994). Also, most of the literature uses the Stolper-Samuelson theorem for the analysis (see Leamer 1994, Richardson 1995, Baldwin and Cain 1997, Lücke 1997, Oscarsson 1997), which makes the latter heavily dependent on the empirical validity of the zero-profit conditions in every sector or period ${ }^{2}$. Using the cost-minimization part of a specific factors model with perfect competition and international capital movements can avoid this drawback and provides a simple way to include the supply of labour, technical change, international trade and factor movements in one framework. Yet, it does so at the cost of slightly exaggerating the immobility aspect of labour (which is now restricted to merely one sector). Other alternatives to the Stolper-Samuelson approach are presented in Francois (1996).

2 . Note that the estimation of Jones' (1970) dynamic version of the zero-profit conditions uses data on factor shares (see Baldwin and Cain 1997), which consist of a cost term in the numerator and revenue terms in the denominator. If we (empirically) have zero-profits on average across time, we might guess from a business cycle perspective that there are losses in recessions and positive profits in booms. This yields higher than average values of cost shares in recessions and lower values in booms. In time series estimates this may bias the results, in particular in view of the possibility that capital and labour shares may be affected unequally because of the irreversibility (or costly reversibility) of the investment of capital which makes it difficult to reduce its cost in a recession. 
To allow for the treatment of more sectors motivated under point ii) above we will construct a multisectoral, specific factors model in section 2. The inclusion of international capital movements brings in interest rate changes in accordance with the motivation of point iii) above. In section 3, some remarks on the data and analysis techniques are made. Section 4 contains our main findings, whereafter section 5 will discuss the policy conclusions which may be drawn from them. Finally, section 6 addresses the limitations of our approach and gives some guidelines for further research.

\section{Model Description}

The details of the model are as follows. For each product $i$ we assume the following production function to be responsible for the generation of variable costs, where $Y$ indicates output, $K$ capital, $L$ labour and $A$ technology:

$$
Y^{i}=\left(K^{i}\right)^{\alpha^{i}}\left(A^{i}\right)^{\theta^{i}}\left(L^{i}\right)^{\beta^{i}}
$$

$\alpha, \beta$ and $\theta$ are elasticities of the production of capital, labour and technology. If the sum of $\alpha$ and $\beta$ is smaller, larger than or equal to one, we have decreasing, increasing or constant returns to scale and therefore upward, downward or constant sloping cost functions (for given technology $A$ ). We do not exclude any of these cases a priori.

From cost minimization we get (with $w$ as the wage rate and $r$ as the interest rate):

$$
\begin{aligned}
w^{i} & =\lambda^{i} F^{i}{ }_{L^{i}} \\
r & =\lambda^{i} F^{i}{ }_{K^{i}}
\end{aligned}
$$

$\lambda$ is the Lagrange multiplier of the technology constraint, whose economic interpretation is marginal costs. Lower indices $K$ or $L$ indicate a partial derivative with respect to $K$ or $L$. The three equations given above allow us to find a solution for the value of the Lagrange multiplier $\lambda$. We get:

$$
\begin{gathered}
\lambda=\left(\frac{r}{\alpha}\right)^{a} Y^{b} A^{c}\left(\frac{w}{\beta}\right)^{d} \\
\text { with } \\
a=\frac{\alpha}{\alpha+\beta}, b=\frac{1-\alpha-\beta}{\alpha+\beta}, c=\frac{-\theta}{\alpha+\beta}, d=\frac{\beta}{\alpha+\beta}
\end{gathered}
$$

In case of perfect competition marginal costs equal prices given from the world market (under the small country assumption) and marginal productivity conditions can therefore be rewritten as:

$$
\begin{gathered}
w^{i}=p^{i} F_{L^{i}}^{i} \\
r=p^{i} F^{i}{ }_{K^{i}}
\end{gathered}
$$

Rewriting the marginal productivity conditions in growth rates, using the CobbDouglas form of production functions, and the elimination of the term for capital 
yields an equation for several sectors in different countries (we do not write down a country index):

$$
\begin{gathered}
\hat{w}^{i}=\gamma_{1} \hat{p}^{i}+\gamma_{2} \hat{r}+\gamma_{3} \hat{A}^{i}+\gamma_{4} \hat{L}^{i} \\
\text { with } \\
\gamma_{1}=\frac{1}{1-\alpha^{i}}, \gamma_{2}=-\frac{\alpha^{i}}{1-\alpha^{i}} \\
\gamma_{3}=\frac{\theta^{i}}{1-\alpha^{i}}, \gamma_{4}=\frac{\beta^{i}+\alpha^{i}-1}{1-\alpha^{i}}
\end{gathered}
$$

In this model, the terms of trade are exogenous in case of perfect competition and the small country assumption. These assumptions are made in most of the related literature. With perfect capital movements the real interest rate, $r$, is given from the world market at each moment in time. Technology is exogenous by assumption and so is labour input because of the assumption that it is specific to each sector. Alternatively, we could have had employment as an endogenous variable and wages as an exogenous one. Then the equation would try to explain employment of a sector in a country ${ }^{3}$.

The right side of the above equation captures all variables that play a role in the debate on real wages. International trade is captured by changes in the terms of trade, technology is contained and international capital movements are represented by changes in the interest rate. Finally, factor supply is included which could not be done in a Stolper-Samuelson approach using the zero-profit assumption.

An estimate of this equation at the firm level would give us a result for $\alpha$, the elasticity of production of capital of a sector in a country, from either $\gamma_{1}$ or $\gamma_{2}$. Therefore we have to impose or test the constraint that:

$$
\gamma_{1}+\gamma_{2}=1
$$

when doing the estimation. Having found a value for $\alpha$ we can deduct the value of $\beta$ from $\gamma_{4}$ and that of $\theta$ from $\gamma_{3}$. The question whether or not we have increasing returns to scale can be answered by looking at $\gamma_{4}$. If it is less than, more than or equal to zero, we have decreasing, increasing or constant returns to scale in labour and capital. However, only if the previous coefficient restriction is accepted we may draw such a conclusion, for then we can suspect that the definitions of the other coefficients hold too. The assumption of perfect competition is only justified if we have non-increasing returns to scale. In the case of increasing returns to scale we have to resort to imperfect competition and endogenous prices. Therefore we must

3. In the standard partial equilibrium labour market diagram an increase in the labour supply would decrease wages. However, the increase in employment has an indirect effect via the marginal productivity of capital, which is increased by higher employment and therefore more capital is attracted from the world market. With the increase in capital, labour demand also increases which would increase wages. Under increasing (decreasing) returns to scale the indirect demand effect is stronger (weaker) than the direct supply effect. 
give up the small country assumption, because price determination by domestic firms and prices given from the world market are mutually exclusive concepts (see Helpman and Krugman 1989). If a sector is faced with a constant-elasticity demand function, $p^{i}=B^{i} Y^{i \phi} M_{e u}^{i \delta} M_{n e u}^{i \varepsilon}$, with $\phi$ as an inverse of the price elasticity, $M_{e u}$ as import quantities of competing products from the EU, $M_{\text {neu }}$ as their non-European equivalent, $B$ as a shift parameter which captures all other demand effects (such as effects of other imports coming into the country), and each product being produced by only one firm (as it would under monopolistic competition), profit maximization will yield $p^{i}=\lambda^{i} /\left(\phi^{i}+1\right)$. Prices are now an endogenous variable because marginal costs $(\lambda)$ are endogenous for they depend on output and wages. A division between European and non-European trade is made because competition from the Asian NICs has been of special interest in the recent debate. If trade has an impact we would expect $\delta, \varepsilon<0$.

Equating prices from the first-order conditions with those of the demand function yields:

$$
B^{i} Y^{i \phi} M_{e u}^{i \delta} M_{\text {neu }}^{i \varepsilon}=\lambda^{i} /\left(\phi^{i}+1\right)
$$

Taking growth rates of this equation, the marginal productivity conditions and the expression for $\lambda$ gives us four linear equations for four endogenous variables: the growth rates of wages $(w)$, capital $(K)$, marginal costs $(\lambda)$ and output $(Y)$. The exogenous variables are the growth rates of $A, B, L, r, M_{e u}$ and $M_{n e u}$. Parameters are $\alpha, \beta, \theta, a, b, c, d, \delta, \varepsilon$ and $\phi$.

Solving the system for the growth rate of wages yields:

$$
\begin{gathered}
\hat{w}^{i}=e_{0}+e_{2} \hat{r}+e_{1 a} \hat{M}_{e u}^{i}+e_{1 b} \hat{M}_{n e u}^{i}+e_{3} \hat{A}^{i}+e_{4} \hat{L}^{i} \\
\text { with } \\
e_{0}=\frac{-\hat{B}}{\alpha(\phi+1)-1}, e_{2}=\frac{\alpha(\phi+1)}{\alpha(\phi+1)-1}, \\
e_{1 a}=\frac{-\delta}{\alpha(\phi+1)-1}, e_{1 b}=\frac{-\varepsilon}{\alpha(\phi+1)-1}, \\
e_{3}=\frac{\frac{\phi(\beta-\theta)}{1-\alpha-\beta}-\beta(\phi+1)}{\alpha(\phi+1)-1}, e_{4}=-1-\frac{\beta(\phi+1)}{\alpha(\phi+1)-1}
\end{gathered}
$$

In this equation, compared to that of the perfect competition case, imports are the exogenous variable that replace prices. The exogenous shift variable $B$ can go either way. If it is decreasing, competition is increased. Therefore, the demand function is shifted towards lower prices.

Once we have estimated $e_{0-4}$, we can successively infer values of $\alpha(\phi+1)$ from $e_{2}, \beta(\phi+1)$ from $e_{4}$ and $\frac{\phi(\beta-\theta)}{1-\alpha-\beta}$ from $e_{3}$. Furthermore, we can obtain the value of 
$\delta$ from $e_{1 a}$, that of $\varepsilon$ from $e_{1 b}$, and the growth rate of $B$ from $e_{0}^{4}$. Then, we do not get to know the sum $(\alpha+\beta)$ and whether or not a sector has increasing returns to scale. Nevertheless, we can derive the following (sufficient) condition which, if it is found to be larger than one, may indicate increasing returns ${ }^{5}$ :

$$
\alpha(\phi+1)+\beta(\phi+1)=\phi(\alpha+\beta)+(\alpha+\beta)>1 \Rightarrow I R S
$$

Moreover, we cannot see whether or not the price elasticity is in the (elastic) range $0>\phi>-1$. What we can see, is whether $\delta, \varepsilon<0$ and $\alpha(\phi+1), \beta(\phi+1)>0$ (if all the coefficient definitions hold). The restrictions follow from the requirement of positive values for the elasticity of production and the requirement that the inverse price elasticity should lie between zero and minus one.

\section{Data and Econometric Methods}

The estimated equations have been derived from the firms' rules for cost minimization and profit maximization. Unfortunately, we do not have data at the firm or product level. Therefore, we performed the estimation at the sectoral level. Aggregating the left and right hand sides of the equation across products to generate a sectoral equation is possible without problems only if all products have the same values for all the parameters or have the same growth rate of all explanatory variables. We are not aware of any solution to this aggregation problem. Assuming that a similar equation holds for sectors may not be too heroic. However, it is anything but clear that the parameter constraints are still reasonable. We will therefore estimate the equations both with and without them.

Having constructed a model that is very similar to those of standard international trade models in textbooks we have to relate a non-monetary model to data that stem from a monetary world. This requires dividing the data for wages and sectoral prices by the GDP price level of the country in question. Moreover, nominal interest rates have to be deflated by subtraction of the growth rate of the GDP deflator. We start from national nominal interest rates, because in spite of our assumptions it is not clear that national capital markets are perfect. Although we have not modelled capital market imperfections explicitly, national rates seem to be the more adequate data.

We will test for structural breaks. The question whether employment drives wages or wages drive employment will be 'answered' using Granger causality tests.

4. Theoretically, this is indeed possible. In practice, since we will be solving a system of six highly non-linear equations, there is no guarantee that either any or just one solution exists.

5. Provided that $\phi$ is negative and $\alpha, \beta>0$. 
The regression equations will be estimated by $\mathrm{OLS}^{6}$ without the aforementioned coefficient restrictions (at least initially). This technique is applied so that a heteroscedasticity-consistent covariance matrix arises ${ }^{7}$. A description of the data can be found in appendix A1. At this point, only the choice of R\&D expenditures as a proxy of technical change will be elaborated upon.

Basically, there are two sets of indicators that can serve as a proxy of technical change: R\&D data and patent statistics. However, both have their drawbacks. R\&D data are an input measure of the innovation process. Not all R\&D inputs lead to innovations, and also the efficiency with which inputs are used influences the amount of successful R\&D efforts. Thus, more R\&D expenditures do not necessarily imply more innovative activities. On the other hand, patent statistics are an output measure of the innovation process. Not all innovations are patented, and not all patents are put to effective and/or commercial use ${ }^{8}$. Moreover, the propensity to patent differs between countries. ${ }^{9}$ In addition, neither R\&D expenditure data nor patent data refer exclusively to process innovation as our model does. At least product innovations for consumers should be excluded (but cannot). Another problem associated with using R\&D statistics as a technology indicator is that series containing labour or capital data will mostly include, to some extent, labour and capital used as an input to R\&D. Thus, adding R\&D as a separate factor in our analysis could create a sort of 'double-counting'. However, there is mixed evidence on both the question if and how far the consequences hereof reach. For example, while Schankerman (1981) and Hall and Mairesse (1992) state that corrections for double-counting should be made ${ }^{10}$, Verspagen (1995) finds only very limited effects. We will not touch upon this issue either, assuming the bias that arises because of double counting to be negligibly small (which seems reasonable, given that the capital variable drops out of the regression equations $)^{11}$.

Nevertheless, the decision to use R\&D expenditures as a proxy of technical change was mainly motivated by data availability, which was larger for R\&D data.

6. Applying NLS or ML (while simultaneously imposing the coefficient restriction derived in the theoretical part) would have been an option, were it not that we would then be implying that the coefficient restriction already holds a priori. Thus, given the reservations expressed above OLS seems to be preferable. Pooling data (across sectors, countries or both) would have been an option too, but it was dropped when relatively little interpretable results emerged. See also footnote 20 and 42 .

7. White's method (1980) is used to achieve this.

8. Scherer (1983) and Griliches (1990) examine the points in favour and against using either R\&D or patent statistics as an indicator of technical change more closely.

9. Cf. Scherer (1983) and Feldman and Florida (1994). See Caniëls (1998) for European evidence hereof.

10 . With the estimated return to R\&D being downward biased.

11. In appendix A1 additional remarks on this subject are made. 


\section{Results and Interpretations}

In section 4.1 we will discuss the estimation results for the perfect competition model, whereafter in section 4.2 the results for the imperfect competition model are examined.

\subsection{The Case of Perfect Competition}

The basic regression output is shown in appendix $\mathrm{B} 1^{12}$. At first, a constant term is included in the regressions to capture the mean effect of (possibly) missing variables (like additional productive factors). We expect $\gamma_{1}$ and $\gamma_{3}$ to have a positive sign, $\gamma_{2}$ to have a negative one, whereas $\gamma_{4}$ and $\gamma_{0}$ (which will be used to denote the constant term) can have either sign. As can be seen, the constant term is (statistically) significant at the 5\% level for entire Germany, almost all of Italy (except for textiles, footwear and leather products and the basic metals sector), whereas it is only significant for total manufacturing and wood, cork and furniture in France, the French, British and Spanish paper and printing industry and the Spanish chemical industry. For the Netherlands and the US, a rather mixed picture emerges (with chemicals, total manufacturing, stone, clay and glass and paper and printing being the significant sectors for the Netherlands and food, drink and tobacco, basic metals, total manufacturing, wood, cork and furniture and other manufacturing industries for the US). Reasons for this outcome may be that labour market aspects (like changes in union power, falling real values of the minimum wage, an upgrading of skills and compensation policies of firms), incomplete capacity utilization, developments in the non-traded sector, or additional production factors (like land and natural resources) are at work (which are all not present in our model).

Most of the other variables do have the expected signs to some degree, but are often not significant, as is typical of the whole literature discussed above. An exception is the labour variable, which is generally both positive and significant (only the British food, drink and tobacco and other manufacturing industries have a negative coefficient). This might point to increasing returns. In a situation of perfect competition (as we have here), it would be inconsistent with our approach for it implies the possibility of ever increasing profits. However, it is far from clear that this is indeed the case because we will show below that we have an aggregation problem in the empirical part (which we already indicated in the theoretical part above) ${ }^{13}$.

It is likely that there are structural breaks underlying the results. Such breaks may especially stem from the movement from negative to positive real interest rates at

12. Three sectors were excluded because of missing R\&D data: the Dutch and Italian wood, cork and furniture sectors and the Dutch other manufacturing industry.

13. An alternative interpretation that is somewhat independent of our model could be that the economy is moving along an upward sloping labour supply curve - a view often found in the work of Bovenberg (see Bovenberg 1995 for details). 
the beginning of the $1980 \mathrm{~s}^{14}$. For Great-Britain, Germany, Italy and the Netherlands, such a change in sign occurs in 1981. In France it occurs in 1980, whereas in Spain and the US, a change in sign of the real interest rate takes place in 1976 and 1986 respectively. Moreover, the dollar value of 1985 may have induced another structural break. To test for these notions, a Chow break test ${ }^{15}$ is applied to both the aforementioned year of the sign change of the real interest rate and the dollar value ${ }^{16}$. The results hereof are also given in appendix B1.

Only a limited number of breaks is found. They arise for total manufacturing and wood, cork and furniture in France, the chemical industry in France and the UK, fabricated metals products in France and Italy, leather products in Italy and the UK and the German other manufacturing industries. Of these sectors, three seem to have been affected by the dollar value of the mid 1980s: total manufacturing in France and the two British sectors ${ }^{17}$. It is decided to let the estimation period for all the aforementioned sectors start in either 1980, 1981 or 1986 instead of (mostly) 1974 and to redo the estimation. The results of this estimation process (taking into account structural breaks) are depicted in appendix B2.

Given that we only found structural breaks for nine sectors, it does not come as a surprise that, although there are changes to be seen (for example, a wrong change in sign in the price variable for fabricated metals products in France and a correct one for the interest variable for the same sector in Italy), the overall results are not very different from those of appendix B1. Thus, structural breaks do not seem to be at the heart of the unexpected signs and large sizes of some of the variables in our model. Factors that remain are the significance of the constant term (in some equations) and the fact that we have not yet imposed the coefficient restriction derived in the theoretical part. If we leave out the constant term for those sectors for which it is statistically insignificant at the 5\% level and then test whether the proposed restriction is in place, we obtain the results of appendix $\mathrm{B} 3{ }^{18}$.

14. From a model point of view, the period characterized by positive real interest rates is the only one of interest, because only then the model holds. It is assumed however that when no structural breaks are found, the influence of negative real interest rates on the regression results is negligibly small.

\section{See Chow (1960) for details.}

16. It is reckoned that econometrically more sophisticated methods exist to assess points in time at which structural breaks occur (see for example Gallant and Fuller 1973). However, we concentrate on the years which we assume to be the most influential.

17. The British chemical industry is also affected by the sign switch of the real interest rate at the beginning of the 1980s.

18. All regressions were also carried out with a time variable included. This variable was always insignificantly different from zero at a 5\% significance level (which is not that surprising since we are working with series expressed in first differences). 
The omission of the constant term alters our results somewhat (leading, among others, to several smaller (yet more significant) values of the labour variable) ${ }^{19}$, but the overall results are quite similar to the ones already reached in appendix B2. Besides, we see that at the 5\% significance level, the coefficient restriction can be accepted only twice. We find significant results for the British chemical industry and Dutch fabricated metal products. Only for these sectors we may, if we get plausible estimates for $\alpha$ and $\beta$, say something about the presence of increasing returns. It is unlikely that plausible estimates arise for both these sectors, because not all coefficients have the expected sign: for chemicals in the UK the labour coefficient is one of the few negative entries, whereas for fabricated metals products in the Netherlands the interest variable turns up with a positive coefficient. In fact, inferring values for $\alpha, \beta$ and $\theta$ does not lead to plausible estimates for any of these two sectors ( $\alpha$ equals either -.010 or $.019, \beta-.083$ or 1.71 and $\theta-.011$ or .430$)^{20}$. Together with the theoretical part this indicates the presence of an aggregation problem (or omitted variables).

Of all variables, labour is for a large part significantly different from zero, whereas especially for the price and interest variables, there are many unexpected entries as far as sign and significance are concerned. However, statements about increasing or decreasing returns to scale cannot be made anymore since the restriction that would give rise to such an outcome is not accepted (and in the cases where it is, unrealistic estimates follow). It can only be said that a significant and mostly positive relationship exists between sectoral wage growth and employment growth in almost all sectors and countries under consideration ${ }^{21}$. One might suggest that specific factors matter, although the less plausible results for the other variables possibly overstates the importance of such a conclusion.

The question remains in what direction the relationship between employment and wages holds. Do wages determine employment or does employment determine wages instead? Tentatively, this question will be 'answered' by means of Granger causality tests.

19. The technology variable now has the desired sign more often and (especially) becomes more significant. This might point to the fact that $R \& D$ expenditures are rather flawed an indicator of technical change. However, putting the technology variable into the residual would then again seem too drastic an action for it would, in a statistical sense, lead to omitted variable bias.

20. If all coefficient definitions given in the theoretical part are substituted into the regression equation and the model is re-estimated by means of NLS, these $\alpha, \beta$ and $\theta$ estimates follow. Of course, it would have been preferable to solve the system numerically. This did not yield any result, for then it is implicitly assumed that the imposed coefficient restriction holds exactly, whereas our test examines whether it holds within a certain margin.

21. Exceptions (with respect to significance) are all British sectors except textiles, footwear and leather products, stone, clay and glass, paper and printing and wood, cork and furniture, the French food, drink and tobacco, stone, clay and glass and other manufacturing industries, food, drink and tobacco in the Netherlands and Spain and the Dutch basic metals sector. 
Granger causality tests ${ }^{22}$ examine whether the occurrence of a certain event (variable) $X$ precedes the occurrence of another event (variable) $Y$ over a certain period of time. Stated differently, it is tested whether variable $Y$ is temporally dependent upon variable $X$. Thus, it is not causality in a strict sense that is analyzed here: it is the order in which events happen that matters ${ }^{23}$. Besides, Granger causality is like a two-way street: only when $X$ Granger causes $Y$, and $Y$ does not (at the same time) Granger cause $X$, we may say that there is temporal dependence of $Y$ upon $X$. More specifically, the following model is estimated:

$$
Y_{t}=\delta_{0}+\sum_{p} \alpha_{p} Y_{t-p}+\sum_{q} \beta_{q} X_{t-q}+\varepsilon_{t},
$$

where $p, q=$ predetermined lag orders,

$\varepsilon_{t}=$ random disturbance term.

The null hypothesis that $X$ does not Granger cause $Y$ is that $\beta_{q}=0 \forall q$ (while simultaneously, $Y$ should not Granger cause $X: \alpha_{p}=0 \forall p$ ). The size of $p$ and $q$ is mostly agreed upon a priori on theoretical grounds. Here, we will assume, letting $Y_{t}$ denote sectoral wage growth and $X_{t}$ the corresponding growth of labour, that $p$ and $q$ range from one to three. Tests were carried out with both one and two lags, but this did not alter our basic results very much. Results are presented in appendix B4.

Employment Granger causes wage growth in a limited number of cases: only for the British fabricated metal products and the food, drink and tobacco sector significant results are found (at a 5\% level of significance). However, wages determine employment growth more often: for three British sectors (chemicals, textiles, footwear and leather products and basic metals) this turns out to be the case. Two other significant results emerge, namely for Spanish leather products and the Italian paper and printing industry. For wood, cork and furniture in Germany and total manufacturing in Great-Britain, there are statistically significant relationships in both directions: wages determine employment and by the same token, employment determines wages. Nevertheless, the conclusion in these cases is the same as for all sectors not mentioned: the Granger causality test is inconclusive.

It is quite interesting that when significant results are found, they occur most often for Great-Britain. There seems to be no apparent reason for this outcome though.

In the 5 cases where wages Granger cause employment growth, the estimation is redone, with wage growth now being an explanatory variable and labour growth the dependent one. As far as the value of the coefficients is concerned, this simply

22. First introduced by Granger (1969). Sims (1972) and others provided tests (mostly) along the same lines, but the Granger causality test is the one most commonly used.

23. See Eels (1991) for a more elaborate analysis hereof. 
means rewriting the equations already shown in appendix $\mathrm{B} 3^{24}$. However, the fit does change, as does the significance of the coefficients. Tests for structural breaks have to be redone too. Also in the first stage, a constant term is included in the regression equation. For the sectors for which it does not differ significantly from zero at the $5 \%$ level of significance ${ }^{25}$, it is dropped and the modified model is reestimated. These 'final' regressions are given in appendix B4.

Note that the desired sign of the explanatory variables switches when moving from wage growth to labour growth as the dependent variable. Only for the relationship between wages and labour it remains the same. Even then, there are many wrong signs to be found ${ }^{26}$. The interest variable does not have the correct sign for any sector. The technology variable has the wrong sign for three sectors: chemicals in the UK and textiles, footwear and leather products in both the UK and Spain. The price variable has the wrong sign for the two non-British sectors. Thus there is no sector for which all variables have the desired sign. Therefore, no new insights on coefficients are created here either ${ }^{27}$.

For those sectors where all coefficients have the expected $\operatorname{sign}^{28}$, it might be illuminating to examine how far the explanatory variables attribute to the explana-

24. Note that it is not necessary to test the validity of the derived coefficient restriction again because of the same reason (as long as the estimation period remains the same). Here, we have to perform this test anew for two sectors: chemicals and leather products in the UK. For the latter sector, the coefficient restriction is accepted, so estimates for $\alpha, \beta$ and $\theta$ can be generated. See also footnote 27.

25. As turned out to be the case for British and Spanish textiles, footwear and leather products and the Italian paper and printing industry.

26. Which is not surprising since coefficients that already had the wrong sign when wages were taken as the dependent variable, will have so now too (as long as the constant term remains either absent or present and the estimation period remains the same).

27. This is the reason why we find no reasonable estimates for $\alpha, \beta, \theta$ in case of leather products in the UK (where we did accept the coefficient restriction): $\alpha$ equals $2.93 \cdot 10^{-3}, \beta 1.50$ and $\theta-.128$. See also footnote 24 .

28. We will only look at cases where employment determines wage growth, because in the reverse situation no sector had all the desired signs. If we had reversed the position of the wage and labour variables in the regression equation and redone the entire analysis up to this point, we would have ended up with 10 sectors to work with (instead of the 17 we have now). Interestingly, 7 out of these sectors are located in the US: chemicals, fabricated metal products, food, drink and tobacco, leather products, basic metals, wood, cork and furniture and total manufacturing. The other sectors are paper and printing in the UK, wood, cork and furniture in France and other manufacturing industries in Spain. Compared to the 17 sectors we find here (see table 4.1 below), we have an overlap for 5 sectors: three American (chemicals, basic metals and wood, cork and furniture), one French (chemicals) and a British one (paper and printing). So if we include both relationships (where labour growth determines wage growth and vice versa), we would have 22 sectors to continue with. Results at the sectoral level are discussed below. 
tion (of variation in) the dependent variable ${ }^{29}$. This means conducting a sort of 'growth accounting' exercise. From appendix B3 we see that there are 17 sectors for which we found the expected signs. None of them is located in Germany. All sectors are shown in table 4.1 below.

Table 4.1 Sectors with correct expected signs.

\begin{tabular}{||ll||}
\hline Country & Sector \\
& \\
USA & Chemicals \\
& Basic metals \\
& Paper and printing \\
France & Wood, cork and furniture \\
& Chemicals \\
& Stone, clay and glass \\
Great-Britain & Wood, cork and furniture \\
& Chemicals \\
& Food, drink and tobacco \\
Netherlands & Paper and printing \\
Italy & Other manufacturing industries \\
Spain & Total manufacturing \\
& Textiles, footwear and leather \\
& Basic metals \\
\hline
\end{tabular}

Except for chemicals, most industries in the table above are the more traditional ones. Perhaps they indeed exhibit cost-minimizing behaviour because of the nature of their activities.

The basic procedure we follow for the 17 sectors where all variables have the expected signs is to take the regression coefficients of appendix B3 and to premultiply them by the means of the corresponding explanatory variables (calculated as an average of the entire estimation period $)^{30}$. Then, this figure is divided by the mean of the dependent variable over the same period and multiplied by 100 to arrive at percentages. Finally, to obtain country figures, unweighted means of these percentages are taken for all sectors in table 4.1 within a certain country.

29. Ideally, we would have preferred looking at variables that have both the expected sign and are statistically significant. However, this is not the case for any sector. Since we do want to give an indication whether either terms of trade or technology drives wage growth most, the present approach is opted for.

30. Alternatively, we could have taken medians or calculated an average based on just the first and last period. However, given the way in which the OLS estimates are obtained, calculating means over the entire estimation period is to be preferred. 
If we leave out total manufacturing ${ }^{31}$, and check the relative importance of all variables in explaining wage growth in a certain country in the way described above, we reach the results presented in table 4.2. For Italy no results at the country level are calculated because of the availability of just one sector.

Table 4.2 Relative importance of explanatory variables in explaining per country wage growth (in percentages) ${ }^{32}$.

\begin{tabular}{|c|c|c|c|c|c|c|}
\hline VARIABLE & Constant (\%) & $\begin{array}{r}\text { Technology } \\
(\%)\end{array}$ & Capital (\%) & Trade $(\%)$ & Labour (\%) & $\begin{array}{r}\text { Residual } \\
(\%)\end{array}$ \\
\hline \multicolumn{7}{|l|}{ COUNTRY } \\
\hline USA & 19.7 & 16.9 & -3.1 & -3.5 & 57.5 & 12.3 \\
\hline France & 0.0 & 28.8 & 30.9 & -3.0 & 79.7 & -36.4 \\
\hline Great-Britain & 40.7 & 23.8 & -18.3 & 31.8 & 16.6 & 5.4 \\
\hline Netherlands & 422.7 & 64.4 & 8.7 & -6.3 & -389.5 & 0.0 \\
\hline Spain & 0.0 & 22.5 & 19.8 & -6.7 & 55.8 & 8.7 \\
\hline
\end{tabular}

Perhaps the first impression table 4.2 gives rise to, is that a large part of the explanation of wage growth is attributed to both the constant term (in the UK and the Netherlands) and the residual (in France). This implies that for these countries a significant part of wage behaviour is not captured by our model as discussed above $^{33}$.

However, it does not mean that we cannot draw any conclusion from the table (at least, preliminary). It is evident that for most countries, a large part of wage growth is determined by employment growth: labour supply is a dominating factor in 4 countries (all but the UK). In the UK, a substantial part is contributed by terms of trade changes ${ }^{34}$. The UK is also the only country where terms of trade are more influential than technology. Looking at the overall results, we may conclude that technology is a more important factor than trade in determining (national) wages in 4 countries. Labour supply is an even more important factor. Again, specific

31. For it is an aggregate across all other sectors and including it would create a bias. In case of the Netherlands however, it will be included to give at least some notion of Dutch wage behaviour.

32. In regressions without a constant term the residuals do not necessarily have to sum to zero. Therefore, a certain weight is assigned to them in these cases.

33. Which was to be expected, given our previous results.

34. Leaving aside the constant term. 
factors seem to matter. This raises the question what we can see at the sectoral level ${ }^{35}$.

We can derive from table $4.3 \mathrm{a}$ below ${ }^{36}$ for the whole period under consideration (and from table $4.3 \mathrm{~b}$ for the 1980s onwards -the results of which we will indicate between brackets-) that 12 (12) out of the 17 sectors included in the 'growth accounting' exercise have negative terms of trade growth, indicating that there may be an international problem. In 7 (7) sectors we have falling and in 10 (10) we have increasing wages (according to the last column). In only 4 (4) sectors R\&D expenditures have a negative growth rate. $R \& D$ therefore has a positive effect on wages in both periods. Interest rates have fallen in 10 (10) sectors and therefore have increased wage growth ${ }^{37}$. With 2 (3) exceptions labour supply has fallen and therefore -given the positive sign of the correlation- decreased wage growth. The earlier period thus is a bit less favourable as far as the growth rate of the labour supply is concerned ${ }^{38}$.

35. A similar exercise was carried out for the period starting (mostly) from 1980 or 1981 onwards. There, we looked at sectors which had (by and large) falling growth rates of wages. With the same regression coefficients (which, in a rough sense, is a valid approach for structural breaks have already been taken into account), we found results that were almost identical to the ones obtained in table 4.2. However, the results for total manufacturing in the Netherlands and food, drink and tobacco in Spain became worse, with respectively $-123.9 \%$ and $-325.1 \%$ of wage growth now being attributed to the residual. On the contrary, we found improved results for France, where technology now emerged as the most prominent factor in wage determination. Moreover, in Spain capital became the most important explanatory factor. Yet overall, labour still turned out to be the most influential factor in national wage formation. More results at the sectoral level are discussed (and shown) later on.

36. Of course, the same data can also be found in appendix A2.

37. The extremely high value for the mean growth rate of the Spanish interest rate is due to an outlier in 1986. Possibly, this outlier is caused by the alliance of Spain with the EU (and it was therefore explicitly taken along in our exercises).

38. In 7 (7) cases the growth rates of $L$ and $w$ have opposite signs, but have positive regression coefficients. The inclusion of other explanatory variables and interaction effects between them play an important role in this 'switch' in sign. 
Table 4.3a Growth rates of explanatory and dependent variables over the estimation period given by SMPL.

\begin{tabular}{|c|c|c|c|c|c|c|}
\hline Sector $^{39}$ & SMPL & Technology & Capital & Trade & Labour & Wages \\
\hline USAZ35 & $74-93$ & 0.0455 & 0.3643 & -0.0019 & 0.0063 & 0.0179 \\
\hline USAZMB & $74-93$ & -0.0049 & 0.3643 & 0.0015 & -0.0286 & -0.0222 \\
\hline USAZOP & $74-93$ & 0.0522 & 0.3643 & 0.0052 & 0.0108 & 0.0179 \\
\hline USAZOW & $74-93$ & 0.0209 & 0.3643 & -0.0056 & 0.0000 & 0.0046 \\
\hline FRAZOG & $74-91$ & 0.0215 & 0.5437 & 0.0010 & -0.0244 & -0.0037 \\
\hline FRAZ35 & $80-91$ & 0.0458 & -0.2758 & -0.0079 & -0.0060 & 0.0030 \\
\hline FRAZOW & $80-91$ & 0.0779 & -0.2758 & -0.0051 & -0.0235 & -0.0082 \\
\hline GBRZLF & 74-92 & -0.0886 & 0.2590 & -0.0047 & -0.0212 & 0.0046 \\
\hline GBRZOO & 74-92 & -0.0019 & 0.2590 & 0.0359 & -0.0253 & 0.0209 \\
\hline GBRZOP & $74-92$ & -0.0022 & 0.2590 & 0.0060 & -0.0101 & 0.0107 \\
\hline GBRZ35 & $86-92$ & 0.0692 & 0.4908 & -0.0210 & -0.0070 & 0.0264 \\
\hline NLDZMT & $74-93$ & 0.0187 & -0.2920 & -0.0095 & -0.0123 & 0.0028 \\
\hline ESPZMB & 80-91 & 0.0173 & -9.5446 & -0.0339 & -0.0399 & -0.0323 \\
\hline ESPZMT & 80-91 & 0.1139 & -9.5446 & -0.0089 & -0.0138 & -0.0078 \\
\hline ESPZOW & 80-91 & 0.5935 & -9.5446 & -0.0047 & -0.0189 & -0.0173 \\
\hline ESPZLF & 80-91 & 0.1110 & -9.5446 & -0.0188 & -0.0085 & 0.0092 \\
\hline ITAZLX & $81-94$ & 0.3001 & 0.1873 & -0.0176 & -0.0197 & -0.0107 \\
\hline
\end{tabular}

39. See appendix A1 for the abbreviations used. 
Table 4.3b Growth rates of explanatory and dependent variables over the estimation period given by SMPL - from the 1980s onwards.

\begin{tabular}{|c|c|c|c|c|c|c|}
\hline Sector & SMPL & Technology & Capital & Trade & Labour & Wages \\
\hline USAZ35 & $81-93$ & 0.0508 & 0.1435 & -0.0153 & 0.0037 & 0.0143 \\
\hline USAZMB & $81-93$ & -0.0311 & 0.1435 & -0.0244 & -0.0377 & -0.0371 \\
\hline USAZOP & $81-93$ & 0.0500 & 0.1435 & 0.0083 & 0.0108 & 0.0214 \\
\hline USAZOW & $81-93$ & 0.0179 & 0.1435 & -0.0023 & 0.0052 & 0.0091 \\
\hline FRAZOG & $80-91$ & 0.0234 & -0.2758 & -0.0023 & -0.0279 & -0.0129 \\
\hline FRAZ35 & $80-91$ & 0.0458 & -0.2758 & -0.0079 & -0.0060 & 0.0030 \\
\hline FRAZOW & $80-91$ & 0.0779 & -0.2758 & -0.0051 & -0.0235 & -0.0082 \\
\hline GBRZLF & $81-92$ & -0.0581 & 0.1612 & 0.0040 & -0.0276 & 0.0052 \\
\hline GBRZOO & $81-92$ & -0.0646 & 0.1612 & 0.0546 & -0.0285 & 0.0417 \\
\hline GBRZOP & $81-92$ & -0.0018 & 0.1612 & 0.0034 & -0.0138 & 0.0153 \\
\hline GBRZ35 & $86-92$ & 0.0692 & 0.4908 & -0.0210 & -0.0070 & 0.0264 \\
\hline NLDZMT & $81-93$ & 0.0209 & 0.0287 & 0.0030 & -0.0072 & 0.0034 \\
\hline ESPZMB & $81-91$ & 0.0116 & -10.2546 & -0.0367 & -0.0449 & -0.0410 \\
\hline ESPZMT & $81-91$ & 0.1085 & -10.2546 & -0.0162 & -0.0138 & -0.0134 \\
\hline ESPZOW & $81-91$ & 0.6157 & -10.2546 & -0.0124 & -0.0182 & -0.0265 \\
\hline ESPZLF & $81-91$ & 0.0940 & -10.2546 & -0.0200 & -0.0063 & 0.0016 \\
\hline ITAZLX & $81-94$ & 0.3001 & 0.1873 & -0.0176 & -0.0197 & -0.0107 \\
\hline
\end{tabular}

From table 4.4a below (and table 4.4b for the more recent period of the 1980s the results of which are again given between brackets-), containing a similar table as table 4.2 but then at the sectoral level, it follows that in 5 (8) out of the 17 sectors terms of trade have a larger impact than technology. This means that technology matters more often over the whole period but terms of trade changes are more influential in the recent period. Out of these 5 (8) sectors, 2 (4) have falling terms of trade. Thus at the sectoral level international trade is quite important. These 2 sectors are located in Spain (basic metals) and the UK (food, drink and tobacco). In the 1980s more Spanish sectors have terms of trade losses but also one sector in the US (basic metals). However, of the 2 (4) sectors 1 (4) have falling wages. The more recent period therefore is (much) less favourable (in terms of losses) than the whole period and the terms of trade are overtaking technology in importance ${ }^{40}$.

40 . This conclusion is independent of the fact that, for some sectors (for example, wood, cork and furniture in France) a large part of wage growth is explained by the residual. Even if we had included a constant term in the regressions for these sectors anyway (and checked whether all variables had the correct signs), the economic interpretation of the results would have remained virtually the same. 
In 11 (12) of the 17 national sectors labour has the strongest impact; in only 4 (4) cases it is technology and in 2 (1) it is trade. In the more recent period labour has become even more important than it already was over the entire period. When counting variables that rank second we find 6 (6) times technology, 2 (6) times trade, 3 (2) times labour and 6 (3) times capital movements by interest changes. The overall impression therefore is that labour supply matters most, technology second and trade and interest rates last (in that order), but in the more recent period terms of trade are catching up with technology. All evaluations have been made without taking the constant term or the residual into account.

Table 4.4a Relative importance of dependent and explanatory variables in explaining per sector wage growth (in percentages).

\begin{tabular}{|c|c|c|c|c|c|c|}
\hline Sector & $\begin{array}{l}\text { Constant } \\
(\%)\end{array}$ & $\begin{array}{l}\text { Technology } \\
(\%)\end{array}$ & Capital (\%) & Trade $(\%)$ & Labour (\%) & Residual (\%) \\
\hline USAZ35 & 0.0 & 53.3 & -2.5 & -0.4 & 30.0 & 19.7 \\
\hline USAZMB & -38.8 & 1.0 & 2.8 & -0.4 & 135.4 & 0.0 \\
\hline USAZOP & 0.0 & 4.7 & -2.5 & 3.0 & 65.1 & 29.6 \\
\hline USAZOW & 117.7 & 8.8 & -10.0 & -16.0 & -0.5 & 0.0 \\
\hline FRAZOG & 0.0 & -72.8 & 86.4 & -13.6 & 251.7 & -151.7 \\
\hline FRAZ35 & 0.0 & 198.8 & 49.5 & -6.4 & -121.7 & -20.1 \\
\hline FRAZOW & 0.0 & -10.8 & -12.3 & 8.1 & 188.8 & -73.7 \\
\hline GBRZLF & 0.0 & -17.7 & -6.5 & -5.9 & 107.4 & 22.7 \\
\hline GBRZOO & 0.0 & -0.9 & -6.4 & 120.4 & 7.6 & -20.8 \\
\hline GBRZOP & 162.8 & -2.0 & -12.2 & 24.0 & -72.5 & 0.0 \\
\hline GBRZ35 & 0.0 & 115.8 & -48.2 & -11.2 & 23.8 & 19.9 \\
\hline NLDZMT & 422.7 & 64.4 & 8.7 & -6.3 & -389.5 & 0.0 \\
\hline ESPZMB & 0.0 & -1.6 & -3.5 & 7.3 & 109.9 & -12.2 \\
\hline ESPZMT & 0.0 & -67.4 & -3.4 & 42.8 & 151.4 & -23.4 \\
\hline ESPZOW & 0.0 & -12.5 & -1.1 & 8.0 & 90.4 & 15.2 \\
\hline ESPZLF & 0.0 & 81.5 & 63.9 & -35.5 & -32.8 & 23.0 \\
\hline ITAZLX & 0.0 & -5.3 & 3.2 & 4.8 & 109.0 & -11.8 \\
\hline
\end{tabular}


Table 4.4b Relative importance of dependent and explanatory variables in explaining per sector wage growth (in percentages) - from the 1980s onwards.

\begin{tabular}{|c|c|c|c|c|c|c|}
\hline Sector & $\begin{array}{l}\text { Constant } \\
(\%)\end{array}$ & $\begin{array}{l}\text { Technology } \\
(\%)\end{array}$ & Capital (\%) & Trade (\%) & Labour (\%) & $\begin{array}{l}\text { Residual } \\
(\%)\end{array}$ \\
\hline USAZ35 & 0.0 & 74.4 & -1.3 & -4.1 & 21.9 & 9.0 \\
\hline USAZMB & -23.2 & 3.7 & 0.7 & 4.1 & 106.5 & 8.2 \\
\hline USAZOP & 0.0 & 3.8 & -0.8 & 4.0 & 54.4 & 38.7 \\
\hline USAZOW & 59.2 & 3.8 & -2.0 & -3.4 & 56.9 & -14.5 \\
\hline FRAZOG & 0.0 & -22.8 & -12.6 & 8.8 & 83.0 & 43.6 \\
\hline FRAZ35 & 0.0 & 198.8 & 49.5 & -6.4 & -121.7 & -20.1 \\
\hline FRAZOW & 0.0 & -10.8 & -12.3 & 8.1 & 188.8 & -73.7 \\
\hline GBRZLF & 0.0 & -10.3 & -3.6 & 4.4 & 124.2 & -14.7 \\
\hline GBRZOO & 0.0 & -14.7 & -2.0 & 91.8 & 4.3 & 20.6 \\
\hline GBRZOP & 113.9 & -1.2 & -5.3 & 9.6 & -69.4 & 52.4 \\
\hline GBRZ35 & 0.0 & 115.8 & -48.2 & -11.2 & 23.8 & 19.9 \\
\hline NLDZMT & 353.2 & 60.0 & -0.7 & 1.7 & -190.3 & -123.9 \\
\hline ESPZMB & 0.0 & -0.8 & -2.9 & 6.3 & 97.6 & -0.2 \\
\hline ESPZMT & 0.0 & -37.6 & -2.1 & 45.6 & 88.7 & 5.4 \\
\hline ESPZOW & 0.0 & -8.5 & -0.7 & 13.8 & 56.8 & 38.6 \\
\hline ESPZLF & 0.0 & 387.6 & 385.6 & -212.0 & -136.2 & -325.1 \\
\hline ITAZLX & 0.0 & -5.3 & 3.2 & 4.8 & 109.0 & -11.8 \\
\hline
\end{tabular}

A similar exercise can be carried out by switching the roles of wage and labour growth in the regression equation and redoing the entire analysis up to this point ${ }^{41}$. Then we would find 10 sectors where all variables have the expected signs ( 5 of which had not been included before), as shown in table 4.5 below.

41. No regression outputs or intermediate results are included for the reversed relationship. However, they can be obtained from one of the authors upon request. 
Table 4.5 Sectors with correct expected signs when the roles of labour and wages are interchanged.

\begin{tabular}{||ll||}
\hline Country & Sector \\
& \\
USA & Chemicals \\
& Fabricated metal products \\
& Food, drink and tobacco \\
& Textiles, footwear and leather products \\
& Basic metals \\
& Total manufacturing \\
France & Wood, cork and furniture \\
Great-Britain & Wood, cork and furniture \\
Spain & Paper and printing \\
\hline
\end{tabular}

Because the majority of the sectors is located in the US (7 out of 10) we might conclude, given the relationship we are studying right now that especially for the US the current specification works quite well (as far as the signs of the variables are concerned).

It is interesting to see what proportion of labour growth is explained by the other variables like we did before. At the national level a result can only be presented for the US, for there is too limited an amount of sectors accepted for the other countries. Table 4.6 lists the relevant statistics.

Table 4.6 Relative importance of explanatory variables in explaining per country wage growth (in percentages).

\begin{tabular}{||lrrrrrr||}
\hline VARIABLE & Constant (\%) & $\begin{array}{r}\text { Technology } \\
(\%)\end{array}$ & Capital (\%) & Trade (\%) & Wages (\%) & $\begin{array}{r}\text { Residual } \\
(\%)\end{array}$ \\
COUNTRY & & & & & & \\
USA & 71.1 & 523.1 & -209.9 & -167.1 & -3251.2 & 3133.9 \\
USA (excl. & 85.3 & -9.1 & -2.3 & -16.4 & 20.1 & 22.5 \\
ZOW) & & & & & & \\
\hline
\end{tabular}

Looking at table 4.6, the large percentages we find for all variables besides the constant term indicate that there may be an outlier between the sectors at hand. This is indeed the case for wood, cork and furniture. Dropping this sector yields the result that the most important variable in determining labour growth in the US is wage growth (leaving aside the constant term and the residual). Trade, technology and capital all play a less important role (in that order).

Again, at the sectoral level some insights can be gained by analyzing both the periods starting from the 1970s and the 1980s. Therefore, in table $4.7 \mathrm{a}$ and $4.7 \mathrm{~b}$ the growth rates for the variables under consideration are shown for these periods. 
Table 4.7a Growth rates of explanatory and dependent variables over the estimation period given by SMPL.

\begin{tabular}{|l|l|c|c|c|c|c||}
\hline Sector & SMPL & Technology & Capital & Trade & Labour & Wages \\
\hline \hline GBRZOP & $74-92$ & -0.0022 & 0.2590 & 0.0060 & -0.0101 & 0.0107 \\
\hline USAZ38 & $74-93$ & 0.0126 & 0.3643 & -0.0157 & -0.0036 & 0.0062 \\
\hline USAZLX & $74-93$ & 0.0320 & 0.3643 & -0.0265 & -0.0199 & -0.0145 \\
\hline USAZMB & $74-93$ & -0.0049 & 0.3643 & 0.0015 & -0.0286 & -0.0222 \\
\hline USAZMT & $74-93$ & 0.0187 & 0.3643 & -0.0085 & -0.0045 & 0.0047 \\
\hline FRAZOW & $80-91$ & 0.0779 & -0.2758 & -0.0051 & -0.0235 & -0.0082 \\
\hline USAZ35 & $74-93$ & 0.0455 & 0.3643 & -0.0019 & 0.0063 & 0.0179 \\
\hline USAZLF & $74-93$ & 0.0294 & 0.3643 & 0.0023 & -0.0020 & 0.0048 \\
\hline USAZOW & $74-93$ & 0.0209 & 0.3643 & -0.0056 & 0.0000 & 0.0046 \\
\hline ESPZOO & $80-91$ & 0.5407 & -9.5446 & -0.0489 & -0.0129 & 0.0017 \\
\hline
\end{tabular}

Table 4.7b Growth rates of explanatory and dependent variables over the estimation period given by SMPL - from the 1980s onwards.

\begin{tabular}{|l|l|c|c|c|c|c||}
\hline Sector & SMPL & Technology & Capital & Trade & Labour & Wages \\
\hline \hline GBRZOP & $81-92$ & -0.0018 & 0.1612 & 0.0034 & -0.0138 & 0.0153 \\
\hline USAZ38 & $81-93$ & 0.0081 & 0.1435 & -0.0216 & -0.0123 & 0.0001 \\
\hline USAZLX & $81-93$ & 0.0470 & 0.1435 & -0.0207 & -0.0197 & -0.0104 \\
\hline USAZMB & $81-93$ & -0.0311 & 0.1435 & -0.0244 & -0.0377 & -0.0371 \\
\hline USAZMT & $81-93$ & 0.0158 & 0.1435 & -0.0137 & -0.0083 & 0.0013 \\
\hline FRAZOW & $80-91$ & 0.0779 & -0.2758 & -0.0051 & -0.0235 & -0.0082 \\
\hline USAZ35 & $81-93$ & 0.0508 & 0.1435 & -0.0153 & 0.0037 & 0.0143 \\
\hline USAZLF & $81-93$ & 0.0241 & 0.1435 & 0.0102 & -0.0019 & 0.0033 \\
\hline USAZOW & $81-93$ & 0.0179 & 0.1435 & -0.0023 & 0.0052 & 0.0091 \\
\hline ESPZOO & $81-91$ & 0.5679 & -10.2546 & -0.0707 & -0.0107 & -0.0067 \\
\hline
\end{tabular}

A general conclusion that can be drawn when comparing the two tables is that the period of the 1980s is less favourable in many respects: for example, more sectors suffer from adverse terms of trade (8 instead of 7) and wage growth (4 instead of 3). Although R\&D growth is larger in the 1980s than in the 1970s for some sectors (paper and printing in the UK, chemicals in the US and other manufacturing industries in Spain), it mostly is smaller than in the earlier period. Even with a slightly different set of sectors, we thus reach the same general result as we did when studying the reversed relationship. 
Table 4.8a Relative importance of dependent and explanatory variables in explaining per sector labour growth (in percentages).

\begin{tabular}{|c|c|c|c|c|c|c|}
\hline Sector & Constant $(\%)$ & $\begin{array}{l}\text { Technology } \\
(\%)\end{array}$ & Capital (\%) & Trade $(\%)$ & Wages $(\%)$ & Residual (\%) \\
\hline GBRZOP & 112.9 & -0.6 & -1.6 & 20.1 & -30.8 & 0.0 \\
\hline USAZ38 & 337.3 & 8.0 & -14.7 & -62.8 & -167.9 & 0.0 \\
\hline USAZLX & 54.9 & 5.1 & -0.7 & -22.3 & 63.1 & 0.0 \\
\hline USAZMB & 34.5 & -0.8 & -1.8 & 0.2 & 67.9 & 0.0 \\
\hline USAZMT & 205.8 & 11.6 & -8.5 & -9.1 & -99.8 & 0.0 \\
\hline FRAZOW & 0.0 & 8.7 & 3.8 & -0.1 & 38.9 & 48.8 \\
\hline USAZ35 & 0.0 & -120.0 & 5.8 & 1.7 & 256.0 & -43.5 \\
\hline USAZLF & 0.0 & 62.1 & -0.2 & 1.0 & -118.9 & 155.9 \\
\hline USAZOW & 0.0 & 3184.2 & -1247.8 & -920.2 & -19607.3 & 18691.2 \\
\hline ESPZOO & 0.0 & 45.4 & 5.3 & -44.5 & -12.4 & 106.3 \\
\hline
\end{tabular}

Table 4.8b Relative importance of dependent and explanatory variables in explaining per sector labour growth (in percentages) - from the 1980s onwards.

\begin{tabular}{|c|c|c|c|c|c|c|}
\hline Sector & Constant (\%) & $\begin{array}{l}\text { Technology } \\
(\%)\end{array}$ & Capital (\%) & Trade $(\%)$ & Wages (\%) & Residual (\%) \\
\hline GBRZOP & 82.6 & -0.4 & -0.7 & 8.4 & -32.2 & 42.3 \\
\hline USAZ38 & 99.7 & 1.5 & -1.7 & -25.6 & -0.7 & 26.9 \\
\hline USAZLX & 55.6 & 7.5 & -0.3 & -17.7 & 45.6 & 9.2 \\
\hline USAZMB & 26.2 & -4.0 & -0.5 & -2.1 & 86.4 & -6.0 \\
\hline USAZMT & 110.7 & 5.2 & -1.8 & -7.8 & -14.8 & 8.5 \\
\hline FRAZOW & 0.0 & 8.7 & 3.8 & -0.1 & 38.9 & 48.8 \\
\hline USAZ35 & 0.0 & -229.0 & 3.9 & 23.8 & 349.8 & -48.5 \\
\hline USAZLF & 0.0 & 53.6 & -0.1 & 4.8 & -86.1 & 127.8 \\
\hline USAZOW & 0.0 & -11.4 & 2.1 & 1.6 & 163.5 & -55.7 \\
\hline ESPZOO & 0.0 & 57.7 & 6.8 & -77.8 & 59.0 & 54.3 \\
\hline
\end{tabular}

Table $4.8 \mathrm{a}$ (and table $4.8 \mathrm{~b}$ for the 1980s - the results of which we will again present between brackets) is a sectoral version of table 4.5 (but now for all countries). We can derive from it that in 3 (5) of the 10 sectors terms of trade have a larger influence on labour growth than technology. Technology thus matters more 
over the whole period, but since the 1980s the terms of trade have gained in importance. This conclusion is in accordance with the one we obtained above.

In 9 (8) of the sectors wages have the largest impact. Technology comes first 1 (0) times, whereas capital and terms of trade hold the first position 0 (0) and 0 (2) times respectively. The influence of the terms of trade on labour growth thus has grown over time. When counting the variables that rank second, we get 5 (5) times technology, 4 (3) times trade, 1 (1) time capital movements and 0 (1) times wages. It will by now not come as a surprise that similar results as above are reached. Wage growth is the most dominant factor is explaining labour growth, with technology in second place, trade third and capital last. The roles of technology and trade switch when looking at the more recent period of the 1980s.

We already stated that the perfect competition version of our model leaves something to be desired for increasing returns cannot be excluded. Yet, despite its deficiencies, it is clear that its results are quite robust: specific factors do indeed seem to matter for wage and/or labour growth, whereas the influence of the terms of trade on the results has risen over time (when set against the role of technology). Nevertheless, it is equally clear that there still is a need to analyze an imperfect competition version of the model.

\subsection{The Case of Imperfect Competition}

The approach that is followed in case of imperfect competition is very similar to the one followed in the perfect competition case. We first ran OLS regressions ${ }^{42}$ on the basic model, which -from a theoretical point of view- now already contains a constant term. As long as $\alpha \leq 1$ and $\phi$ is in the elastic range $0>\phi>-1$, we expect $e_{1 a}$ and $e_{1 b}$ to have a negative sign, while $e_{0}, e_{3}$ and $e_{4}$ can have either sign (although $e_{3}$ is highly likely to be positive). The results of the estimations are shown in appendix B5.

We see that the constant term $\left(e_{0}\right)$ differs significantly from zero at the $5 \%$ significance level only 19 times. These are all positive entries. Negative entries turn up only 10 times. A similar conclusion holds with respect to the coefficients of the import variables $\left(e_{1 a}\right.$ and $\left.e_{1 b}\right)$ : the coefficient for EU-imports differs significantly from zero 5 times, which are all positive entries but two. It has the desired sign 29 times. Non-European imports turn up significantly 9 times (of which three entries are negative), with a total of 27 negative signs. Thus, non-European imports, including those of the Asian NICs, may have a substantial impact on wage growth in some sectors. Given the construction of $e_{1 a}$ and $e_{1 b}$, they should have the same sign. This happens only 22 times.

Technology is significant only 5 times (of which two entries are negative), and has a positive sign 46 times. The interest rate turns up significantly 11 times too, with seven negative coefficients. Negative signs occur 29 times in total.

42. NLS and ML regressions were also tried (with either the results from the OLS regressions or zero as starting values), but this yielded hardly any result (convergence only occurred when running NLS regressions from zero. If we had continued with these figures, the results presented below would remain roughly the same). 
Labour again is by far the most significant variable. It turns up so 51 times this time. All significant entries are positive ones; negative entries occur only 4 times. Given the highly non-linear way in which $\alpha, \beta$ and $\theta$ appear in the expressions of $e_{0-4}$, we cannot conclude whether there are increasing returns to scale or not. Yet, we can say something about this later on when we analyze the sufficient condition put forward in the theoretical part.

As compared to the results presented in appendix B1, it is striking that for many sectors the fit improves: the imperfect-competition version of our model thus picks up some factors that were (unjustly) left out at the perfect competition stage.

In sum, we may state that for the larger part of the sectors the assumption that $\alpha \leq 1$ probably does not hold. Although in principle the violation of the assumption does not pose a big problem per $\mathrm{se}^{43}$, it may again be that there are structural breaks underlying the results. Therefore, we performed a Chow structural break test for (mostly) the years 1981 and 1986 and checked whether such breaks were present ${ }^{44}$.

Structural breaks were found for 9 sectors: four British (chemicals, food, drink and tobacco, leather products and total manufacturing), one American (basic metals), two Italian (chemicals and fabricated metal products) and two Dutch ones (basic metals and total manufacturing). For only three of them, we also found structural breaks in the perfect competition case ${ }^{45}$. The estimation for these sectors was redone, with the estimation period now mostly starting in $1986^{46}$. The revised regression results are presented in appendix B6. Note that the results are split into two groups: the cases where employment growth determines wage growth and the cases where wage growth determines employment growth ${ }^{47}$.

43. As long as $\alpha(\phi+1) \leq 1$ (as indicated in section 2). Yet, the 'conflict' in sign between the two import variables may lead us to the conclusion that even the current specification leaves something to be desired. Do note however, that this sign 'conflict' may be due to multicollinearity: the two import variables have a correlation that is mostly larger than .60 (and often exceeds .80). Although there are solutions to multicollinearity (for example, dropping one of the collinear variables), this is not an option in the present context for it would imply an explicit change of the theoretical model.

44. Why these years were chosen has been set out in section 4.1.

45 . These sectors are the British chemical and leather products industries and Italian fabricated metal products.

46. Exceptions are the British food, drink and tobacco sector and the Italian chemical and Dutch basic metal industries. For these sectors the estimation period started in 1981 instead of 1986.

47. The results of Granger causality tests in appendix B4 are still valid. For the sectors where we found structural breaks, this implies that in two British cases (chemicals and leather products) labour is taken as the independent variable and wages as an explanatory one, and the entire estimation procedure has to be redone (including testing for structural breaks). So in effect, the structural break tests that were carried out change the results for only seven sectors instead of nine. 
Some changes occur for the aforementioned sectors. We find both correct sign switches (for example in case of the interest variable for Italian chemicals, the European import variable for total manufacturing in the Netherlands and its nonEuropean counterpart for basic metals in the US and the Netherlands), coupled with incorrect ones - sometimes even within the same sectors (for example in case of the interest and non-European import variable for total manufacturing in the Netherlands and also the latter variable for total manufacturing in the UK). So overall, no very new insights on coefficients are created here either.

Nevertheless, it remains quite difficult to be more specific about the results without actually knowing the values of the parameters $\alpha, \beta, \delta, \varepsilon, \theta, \phi$ and $\hat{B}$. Therefore, we put the estimated coefficients of the imperfect-competition model in the general expressions depicted in the theoretical part, and solve the system of equations we get for $e_{0-4}$ numerically. To ensure that we have a system of six equations for six unknowns (which hopefully can be solved), $\alpha(\phi+1), \beta(\phi+1)$ and $\frac{\phi(\beta-\theta)}{1-\alpha-\beta}$ are taken as single coefficients. The outcome of this procedure is shown in appen$\operatorname{dix}$ B7.

We may recall from section 2 that there are several conditions which have to hold in order to fulfill the requirements of the model. These conditions are that $\delta, \varepsilon<0$ and that $\alpha(\phi+1), \beta(\phi+1)>0$. If we look at the 62 sectors for which labour growth explains wage growth, we find that $\delta$ is smaller than zero 32 times, while $\varepsilon$ is so even 38 times. However, when taken together they are negative only 14 times. A similar conclusion is reached for the $\alpha(\phi+1)$ and $\beta(\phi+1)$ terms: the first one is almost always positive (in 59 out of 62 cases) ${ }^{48}$, while the latter is positive 34 times. But together they have a positive value on just 32 occasions. The growth rate of the exogenous shift variable $B$ receives a negative value 28 times, indicating that in about half of our cases the demand function is indeed shifted towards lower prices.

Combining the results for $\delta, \varepsilon, \alpha(\phi+1)$ and $\beta(\phi+1)$, we find that only 5 sectors fulfill all requirements: total manufacturing in the US, paper and printing and fabricated metal products in the Netherlands, the British other manufacturing industries and food, drink and tobacco in Spain. For all these sectors we may even conclude that increasing returns to scale are at work, for the sum of $\alpha(\phi+1)$ and $\beta(\phi+1)$ ranges between 1.18 and $4.14^{49}$. When we only look at the question whether there are increasing returns, our sufficient condition tells us that this is the case for 39 sectors. Especially in the US and the Netherlands increasing returns are found. On the contrary, we find (much) less evidence of increasing returns in the

48. With stone, clay and glass in Italy and leather products and food, drink and tobacco in France as the exceptions.

49. The values for total manufacturing in the US (4.14) and paper and printing in the Netherlands (3.43) are somewhat improbable however. 
UK and Germany ${ }^{50} . M_{\text {nе }}$ depresses prices as much as $M_{e u}$ if we look at the 14 cases where both $\delta$ and $\varepsilon$ are negative $(\delta>\varepsilon 7$ times). Imports from the Asian NICs thus seem to have no larger impact on wages than imports from the EU.

For the 5 sectors where we accepted all requirements a similar 'growth accounting' exercise as in the previous section can be conducted. No such exercise will be conducted at the national level however, since we have too little observations available within every country to do so. Growth rates at the sectoral level are presented in table $4.9 \mathrm{a}$ (for the whole period) and $4.9 \mathrm{~b}$ (for the period starting from the 1980s). Again, they yield the same conclusion reached in the perfect competition case: the period of the 1980s is less favourable in almost all respects. Most variables have smaller growth rates in the later period (maybe except for the labour variable, where 3 out of 5 sectors have larger growth rates).

Table 4.9a Growth rates of explanatory and dependent variables over the estimation period given by SMPL.

\begin{tabular}{||l|l|r|r|r|r|r|c||}
\hline Sector & SMPL & Technology & Capital & EU trade & \multicolumn{1}{l|}{$\begin{array}{l}\text { Non-EU } \\
\text { trade }\end{array}$} & \multicolumn{1}{l|}{ Labour } & Wages \\
\hline \hline USAZMT & $74-92$ & 0.0227 & 0.3942 & 0.0434 & 0.0671 & -0.0047 & 0.0041 \\
\hline GBRZOO & $74-92$ & -0.0019 & 0.2590 & 0.1049 & 0.0200 & -0.0253 & 0.0209 \\
\hline NLDZOP & $74-92$ & 0.0106 & -0.2976 & 0.0587 & 0.0363 & 0.0012 & 0.0160 \\
\hline NLDZ38 & $74-92$ & 0.0153 & -0.2976 & 0.0354 & 0.0677 & -0.0099 & 0.0037 \\
\hline ESPZLF & $80-91$ & 0.1110 & -9.5446 & 0.1244 & 0.0275 & -0.0085 & 0.0092 \\
\hline
\end{tabular}

Table 4.9b Growth rates of explanatory and dependent variables over the estimation period given by SMPL - from the 1980s onwards.

\begin{tabular}{|l|l|r|r|r|r|r|c||}
\hline Sector & SMPL & Technology & \multicolumn{1}{l|}{ Capital } & EU trade & \multicolumn{1}{l}{$\begin{array}{l}\text { Non-EU } \\
\text { trade }\end{array}$} & Labour & Wages \\
\hline \hline USAZMT & $81-92$ & 0.0218 & 0.1724 & 0.0395 & 0.0551 & -0.0090 & 0.0001 \\
\hline GBRZOO & $81-92$ & -0.0646 & 0.1612 & 0.0443 & -0.0061 & -0.0285 & 0.0417 \\
\hline NLDZOP & $81-92$ & 0.0146 & 0.0464 & 0.0480 & 0.0350 & 0.0041 & 0.0182 \\
\hline NLDZ38 & $81-92$ & 0.0177 & 0.0464 & 0.0440 & 0.0778 & -0.0061 & 0.0033 \\
\hline ESPZLF & $81-91$ & 0.0940 & -10.2546 & 0.1363 & 0.0556 & -0.0063 & 0.0016 \\
\hline
\end{tabular}

The final growth accounting results for both periods are given in table 4.10a and $4.10 \mathrm{~b}$ below. What we see (indicating the results for the 1980s between brackets),

50 . Exceptions are food, drink and tobacco in both the UK and Germany and paper and printing, stone, clay and glass and other manufacturing industries in the UK. 
is that wage growth is dominated by labour growth in all but 2 sectors (other manufacturing industries in the UK and food, drink and tobacco in Spain in both periods). There, twice EU trade (technology and non-EU trade) are the most important. In answering the question whether technology or trade (EU and non-EU) drive wage growth most, we find 1 (2) times technology and 4 (3) times trade. Thus for the above sectors the roles of technology and trade are reversed as compared to the case of perfect competition: now technology (instead of trade) is more important during the 1980s. However, this may be caused by a kind of 'selection bias'. After all, we are analyzing just 5 sectors. When looking at variables that rank in second place, we find 1 (1) time technology, 2 (3) times trade, 1 (1) labour and 1 (0) capital movements. Overall, technology seems to have gained in importance over time, the influence of trade has become slightly less whereas labour matters most here too.

Table 4.10a Relative importance of dependent and explanatory variables in explaining per sector wage growth (in percentages).

\begin{tabular}{|c|c|c|c|c|c|c|c|c|}
\hline Sector & SMPL & $\begin{array}{l}\text { Constant } \\
(\%)\end{array}$ & $\begin{array}{l}\text { Technology } \\
(\%)\end{array}$ & $\begin{array}{l}\text { Capital } \\
(\%)\end{array}$ & $\begin{array}{l}\text { EU } \\
\text { trade } \\
(\%)\end{array}$ & $\begin{array}{l}\text { Non-EU } \\
\text { trade } \\
(\%)\end{array}$ & $\begin{array}{l}\text { Labour } \\
(\%)\end{array}$ & $\begin{array}{l}\text { Residual } \\
(\%)\end{array}$ \\
\hline USAZMT & $74-92$ & 200.5 & 50.2 & -14.6 & -13.7 & -9.8 & -112.7 & 0.0 \\
\hline GBRZOO & $74-92$ & 38.9 & 1.1 & 0.6 & 25.1 & 10.6 & 23.6 & 0.0 \\
\hline NLDZOP & $74-92$ & 101.3 & -0.3 & -1.9 & -6.3 & -0.3 & 7.6 & 0.0 \\
\hline NLDZ38 & $74-92$ & 544.7 & 19.8 & 21.0 & -74.4 & -116.5 & -294.6 & 0.0 \\
\hline ESPZLF & $80-91$ & 125.5 & 64.3 & 99.8 & -99.9 & -66.8 & -22.9 & 0.0 \\
\hline
\end{tabular}

Table 4.10b Relative importance of dependent and explanatory variables in explaining per sector wage growth (in percentages) - from the 1980s onwards.

\begin{tabular}{|c|c|c|c|c|c|c|c|c|}
\hline Sector & SMPL & $\begin{array}{l}\text { Constant } \\
(\%)\end{array}$ & $\begin{array}{l}\text { Technology } \\
(\%)\end{array}$ & $\begin{array}{l}\text { Capital } \\
(\%)\end{array}$ & $\begin{array}{l}\text { EU } \\
\text { trade } \\
(\%)\end{array}$ & $\begin{array}{l}\text { Non-EU } \\
\text { trade } \\
(\%)\end{array}$ & $\begin{array}{l}\text { Labour } \\
(\%)\end{array}$ & $\begin{array}{l}\text { Residual } \\
(\%)\end{array}$ \\
\hline USAZMT & $81-92$ & 9514.0 & 2287.5 & -302.2 & -589.7 & -384.0 & -10226.1 & -199.5 \\
\hline GBRZOO & $81-92$ & 19.4 & 18.8 & 0.2 & 5.3 & -1.6 & 13.3 & 44.5 \\
\hline NLDZOP & $81-92$ & 89.1 & -0.3 & 0.3 & -4.5 & -0.3 & 23.0 & -7.3 \\
\hline NLDZ38 & $81-92$ & 625.4 & 26.3 & -3.8 & -106.0 & -153.6 & -206.5 & -81.8 \\
\hline ESPZLF & $81-91$ & 705.2 & 306.1 & 602.7 & -614.8 & -760.5 & -95.3 & -43.3 \\
\hline
\end{tabular}

The results for the 5 sectors for which the role of labour and wages has been interchanged on the basis of Granger causality tests hardly alters the conclusions reached above. Indeed, here only one sector fulfills all the previous require- 
ments: paper and printing in Italy ${ }^{51}$. Although the small number of sectors for which all requirements are met may cast some doubt on the validity of our entire model, we should not forget the fact that we are still -and always will be- faced with an aggregation problem which clearly can have distorted our results (even if the model were correct in itself).

Yet, altering the role of wage and labour growth in all equations may be an interesting route to follow for in that way we can check the robustness of some of the conclusions reached previously. In doing so, we find expected signs of the parameters for 6 sectors: fabricated metal products and stone, clay and glass in Germany, chemicals in the Netherlands and France and stone, clay and glass and paper and printing in Italy ${ }^{52}$. We will perform another 'growth accounting' exercise for these sectors. Table $4.11 \mathrm{a}$ and $4.11 \mathrm{~b}$ list the relevant growth rates.

Table 4.11a Growth rates of explanatory and dependent variables over the estimation period given by SMPL.

\begin{tabular}{||l|l|c|c|c|c|c|c||}
\hline Sector & SMPL & Technology & Capital & EU trade & \multicolumn{1}{l|}{$\begin{array}{l}\text { Non-EU } \\
\text { trade }\end{array}$} & Labour & Wages \\
\hline \hline DEUZ38 & $74-92$ & 0.0519 & 0.0733 & 0.0683 & 0.0933 & 0.0018 & 0.0260 \\
\hline DEUZOG & $74-92$ & 0.0684 & 0.0733 & 0.0348 & 0.0561 & -0.0178 & 0.0009 \\
\hline FRAZ35 & $74-91$ & 0.0427 & 0.5437 & 0.0641 & 0.0917 & -0.0050 & 0.0187 \\
\hline ITAZOG & $74-92$ & 0.1193 & 0.6333 & 0.0295 & 0.0561 & -0.0091 & 0.0111 \\
\hline ITAZOP & $81-92$ & -0.0066 & 0.2304 & 0.0304 & 0.0089 & -0.0119 & 0.0062 \\
\hline NLDZ35 & $74-92$ & 0.0309 & -0.2976 & 0.0528 & 0.0839 & -0.0015 & 0.0141 \\
\hline
\end{tabular}

51. Note that in this case (as compared to the perfect competition one) we can use the same expected signs as we did before when interpreting the results for the equations where the role of labour and wages has been interchanged.

52. No intermediate results will be shown here either, but they are available from one of the authors upon request. 
Table 4.11b Growth rates of explanatory and dependent variables over the estimation period given by SMPL - from the 1980s onwards.

\begin{tabular}{||l|l|c|c|c|c|c|c||}
\hline Sector & SMPL & Technology & Capital & EU trade & \multicolumn{1}{l|}{$\begin{array}{l}\text { Non-EU } \\
\text { trade }\end{array}$} & Labour & Wages \\
\hline \hline DEUZ38 & $81-92$ & 0.0420 & 0.0447 & 0.0672 & 0.0841 & 0.0060 & 0.0223 \\
\hline DEUZOG & $81-92$ & 0.0171 & 0.0447 & 0.0319 & 0.0553 & -0.0138 & -0.0016 \\
\hline FRAZ35 & $80-91$ & 0.0458 & -0.2758 & 0.0357 & 0.0441 & -0.0060 & 0.0030 \\
\hline ITAZOG & $81-92$ & 0.0812 & 0.2304 & 0.0079 & 0.0276 & -0.0092 & 0.0047 \\
\hline ITAZOP & $81-92$ & -0.0066 & 0.2304 & 0.0304 & 0.0089 & -0.0119 & 0.0062 \\
\hline NLDZ35 & $81-92$ & 0.0343 & 0.0464 & 0.0256 & 0.0033 & 0.0060 & 0.0165 \\
\hline
\end{tabular}

From the above growth rates we can derive that for the 6 sectors included the recent period of the 1980s is much less favourable for all variables except labour: they have smaller growth rates more often than over the entire period. The mean wage growth rate for German paper and printing even becomes negative. Thus we can reinforce the conclusions already made before. This raises the question what we find when analyzing the impact of all variables on wage growth (in percentages). Table $4.12 \mathrm{a}$ and $4.12 \mathrm{~b}$ give an indication hereof.

Table 4.12a Relative importance of dependent and explanatory variables in explaining per sector labour growth (in percentages).

\begin{tabular}{|c|c|c|c|c|c|c|c|c|}
\hline Sector & SMPL & $\begin{array}{l}\text { Constant } \\
(\%)\end{array}$ & $\begin{array}{l}\text { Technology } \\
(\%)\end{array}$ & $\begin{array}{l}\text { Capital } \\
(\%)\end{array}$ & $\begin{array}{l}\text { EU } \\
\text { trade } \\
(\%)\end{array}$ & $\begin{array}{l}\text { Non-EU } \\
\text { trade } \\
(\%)\end{array}$ & $\begin{array}{l}\text { Wages } \\
(\%)\end{array}$ & $\begin{array}{l}\text { Residual } \\
(\%)\end{array}$ \\
\hline DEUZ38 & $74-92$ & -858.4 & 57.8 & -35.2 & -31.6 & -80.6 & 1048.1 & 0.0 \\
\hline DEUZOG & $74-92$ & 91.0 & 3.5 & 2.3 & 4.8 & 1.6 & -3.2 & 0.0 \\
\hline FRAZ35 & 74-91 & 131.0 & 1.1 & 15.9 & 2.1 & 40.9 & -91.0 & 0.0 \\
\hline ITAZOG & $74-92$ & 168.3 & -13.7 & 6.2 & 0.0 & 47.5 & -108.4 & 0.0 \\
\hline ITAZOP & $81-92$ & 119.0 & 0.1 & 9.2 & 18.1 & 0.3 & -46.7 & 0.0 \\
\hline NLDZ35 & 74-92 & 531.4 & -80.0 & 2.5 & 65.4 & 38.4 & -457.8 & 0.0 \\
\hline
\end{tabular}


Table 4.12b Relative importance of dependent and explanatory variables in explaining per sector labour growth (in percentages) - from the 1980s onwards.

\begin{tabular}{||l|l|l|l|l|l|l|l|l||}
\hline Sector & SMPL & $\begin{array}{l}\text { Constant } \\
(\%)\end{array}$ & $\begin{array}{l}\text { Technology } \\
(\%)\end{array}$ & $\begin{array}{l}\text { Capital } \\
(\%)\end{array}$ & $\begin{array}{l}\text { EU } \\
\text { trade } \\
(\%)\end{array}$ & $\begin{array}{l}\text { Non-EU } \\
\text { trade } \\
(\%)\end{array}$ & $\begin{array}{l}\text { Wages } \\
(\%)\end{array}$ & $\begin{array}{l}\text { Residual } \\
(\%)\end{array}$ \\
\hline \hline DEUZ38 & $81-92$ & -257.6 & 14.0 & -6.4 & -9.3 & -21.8 & 270.0 & 111.1 \\
\hline DEUZOG & $81-92$ & 117.6 & 1.1 & 1.8 & 5.7 & 2.0 & 7.7 & -35.9 \\
\hline FRAZ35 & $80-91$ & 108.7 & 0.9 & -6.7 & 1.0 & 16.3 & -12.0 & -8.3 \\
\hline ITAZOG & $81-92$ & 256.0 & -8.0 & -4.1 & 0.0 & 56.9 & -44.0 & -156.9 \\
\hline ITAZOP & $81-92$ & 119.0 & 0.1 & 9.2 & 18.1 & 0.3 & -46.7 & 0.0 \\
\hline NLDZ35 & $81-92$ & -128.2 & 21.4 & 0.1 & -7.7 & -0.4 & 129.8 & 85.0 \\
\hline
\end{tabular}

Even when switching the roles of labour and wages, the main conclusion remains that specific factors matter: wage growth has the largest impact on labour growth in 5 (4) out of 6 sectors. Only for German paper and printing (French chemicals and Italian stone, clay and glass) it is EU trade (twice non-EU trade). Removal of fabricated metal products in Germany (which can be regarded as an outlier) does not change this result substantially. Trade explains a larger percentage of labour growth than technology in all but one sector (Dutch chemicals in both periods). Given that non-EU trade sometimes even exhibits the most explanatory power during the 1980s (for French chemicals and stone, clay and glass in Italy), we may sustain the hypothesis that competition from the Asian NICs has risen in importance over the years.

Combining the sectors we worked with above with the 22 non-overlapping sectors we found in the perfect competition case, we have a group of 29 sectors (excluding overlap) for which either a perfect or an imperfect competition approach seems acceptable. With a total of 67 sectors, the aggregation problem thus seems to have serious effects on the performance of our model. Nevertheless, the evidence that can be obtained from the imperfect competition model is that the main conclusions of the perfect competition model are endorsed. Specific factors are important and the role of both technology and trade in explaining wage and/or labour growth changes (with trade being influential in both periods) has clearly come forward.

\section{Policy Conclusions}

Under perfect competition and the small country assumption protectionism is damaging. It is here that the whole discussion has its policy relevance. Firms and sectoral institutions ask governments for protectionism or for compensation for losses from trade. One such policy action has been the Trade Adjustment Assistance Program in the US. Sachs and Shatz (1994) show that the sectoral distribution of compensations from that program are strongly correlated with the underlying sectoral distribution of sectoral employment losses. In our analysis of the perfect 
competition case we found that 7 (7) of the sectors that have a negative effect from adverse terms of trade movements have decreasing wages. Although admittedly the evidence is not overwhelming, one could ask the crucial question whether income policies for the short run and R\&D subsidies for the long run would be a better means to help sectors like these than protectionism. As international trade has gained in importance since the 1980s this question has become more urgent for some sectors.

However, it should be clear that behind the given interest rate there is a critical issue of interest rate determination and behind the given sectoral labour supply and wages there are labour market imperfections. Given the dominance of the labour supply variable in both the perfect and the imperfect competition version of our model, it seems reasonable to search for a diagnosis and a solution to problems in the labour market sphere. There, specific factors have turned out to be a robust variable that is more important than both technology and trade.

\section{Limitations and Suggestions for Further Research}

The major drawback of a trade-theoretic approach is that international trade models are not related to models explaining unemployment and vice versa. The state of the art in the literature thus seems to be somewhat unsatisfactory. This is the reason why economists currently have to choose between a closed economy labour market imperfections approach and a first-best trade approach. The integration of the two must be left for further research. Moreover, due to the simplifying assumption of constant price elasticities of demand and therefore of mark-ups over marginal costs, we cannot include their change across the business cycle without considerably complicating the model.

An incentive for further research from our analysis follows from three results. First, in the perfect competition case the constant term in our model was absent but the empirics tell us that we should have one (thus indicating that there are possibly other explanatory variables that should have been included in the model). Second, the model would predict relations between the coefficients, but the corresponding constraint has been rejected by statistical tests. Third, we could not exclude increasing returns to scale in case of perfect competition, while we only found some preliminary evidence hereof in the imperfect competition case. Nevertheless, as can be concluded from the rejection of the imposed constraint in the perfect competition model and the unsatisfactory results reached for most sectors with imperfect competition, we are still faced with an aggregation problem. Thus, we cannot actually prove that the assumption of perfect competition is wrong. So, even if our model and estimation results are rather crude to give a 'robust' answer to the question what factor drives sectoral wage growth most strongly (technology or trade), our results do have some relevance. In particular, the supply of specific factors turned out to matter in both models (with the results being very robust in that respect) and the changing role of international trade (becoming more important than technology in the 1980s according to the perfect competition model) has been clearly illustrated. 


\section{References}

Alier, J.M. (1997), 'Ecological Economics and Environmental Policy: A Southern European View'. In: Tylecote, A.B. and van der Straaten, J.C. (ed.), Environment, Technology and Economic Growth: The Challenge to Sustainable Development, Edward Elgar Publishing Company, Aldershot, 1997.

Baldwin, R.E. and Cain, G.G, 'Shifts in U.S. Relative Wages: The Role of Trade, Technology and Factor Endowments', NBER WP 5934 (1997).

Bovenberg, L, 'Environmental Taxation and Employment', De Economist 143 (1995), no. 2.

Caniëls, M.C.J., 'The Geographic Distribution of Patents and Value Added across European Regions', MERIT Research Memorandum 98-004 (1998).

Chow, G.C., 'Tests of Equality between Sets of Coefficients in Two Linear Regressions', Econometrica 28 (1960), pp. 591-605.

Eels, E., Probabilistic Causality, Cambridge University Press, Cambridge, 1991.

Freeman, R. B., 'Are your Wages set in Beijing?', Journal of Economic Perspectives 9 (1995), pp. 15-32.

Feldman, M.P. and Florida, R., 'The Geographic Sources of Innovation: Technological Infrastructure and Product Innovation in the United States', Annals of the Association of American Geographers 84 (1994), pp. 210-229.

Francois, J.F. , 'Trade, Labour Force Growth and Wages', The Economic Journal 106 (1996), pp. 1586-1609.

Gallant, A.R. and Fuller, W.A., 'Fitting Segmented Polynomial Regression Models whose Joint Points have to be Estimated', Journal of the American Statistical Association 68 (1973), pp. 144-147.

Granger, C.W.J., 'Investigating Causal Relations by Econometric Models and CrossSpectral Methods', Econometrica 44 (1969), pp. 424-438.

Griliches, Z., 'Patent Statistics as Economic Indicators: A Survey', Journal of Economic Literature 28 (1990), pp. 1661-1707.

Hall, B.H. and Mairesse, J., 'Productivity and R\&D at the Firm Level', NBER WP 3956 (1992).

International Financial Statistics Yearbook 1990, Publication of the IMF, International Monetary Fund Publication Services, Washington, 1990. 
International Financial Statistics Yearbook 1995, Publication of the IMF, International Monetary Fund Publication Services, Washington, 1995.

Jones, R.W., 'The Role of Technology in The Theory of International Trade'. In: Vernon, R. (ed.), The Technology Factor in International Trade, NBER, New York, 1970.

Krugman, P.R., 'Competitiveness: A Dangerous Obsession', Foreign Affairs, March/April 1994.

Krugman, P.R. and Obstfeld, M., International Economics, $4^{\text {th }}$ edition, AddisonWesley Publishing Company, Reading, 1997.

Lawrence, R.Z. and Slaughter, M.J., 'International Trade and American Wages in the 1980s: Giant Sucking Sound or Small Hiccup', Brookings Papers on Economic Activity, 2 (1993), pp. 161-226.

Leamer, E.E., 'Wage Inequality from International Competition and Technological Change: Theory and Country Experience', American Economic Review, AEA Papers and Proceedings, May 1996.

Leamer, E.E., 'Trade, Wages and Revolving Door Ideas', NBER WP 4716 (1994).

Leamer, E.E., 'Wage Effects of a U.S. Mexican Free Trade Agreement'. In: Garber, P.M. (ed.), The Mexico-U.S. Free Trade Agreement, MIT Press, Cambridge, 1993.

Lücke, M., 'European Trade with Lower-Income Countries and the Relative Wages of the Unskilled: An Exploratory Analysis for West-Germany and the UK', Kiel University WP 819 (1997).

Oliveira Martins, J., 'Market Structure, Trade and Industry Wages', OECD Economic Studies No. 22, Spring 1994, pp. 131-154.

Oscarsson, E., 'Trade and Relative Wages in Sweden 1968-91', Department of Economics, Stockholm University Research Memorandum, January 1997.

Richardson, J.D., 'Income Inequality and Trade: How to Think, What to Conclude', Journal of Economic Perspectives 9 (1995), pp. 33-55.

Sachs, J.D. and Shatz, H.J., 'Trade and Jobs in U.S. Manufacturing', Brookings Papers on Economic Activity 1 (1994), pp. 1-84.

Schankerman, M., 'The Effects of Double-Counting and Expensing on the Measured Returns to R\&D', Review of Economics and Statistics 63 (1981), pp. 454-458. 
Scherer, F.M., 'The Propensity to Patent', International Journal of Industrial Organization 1 (1983), pp. 107-128.

Sims, C.A., 'Money, Income and Causality', American Economic Review 62 (1972), pp. 540-555.

Verspagen, B., 'R\&D and Productivity: A Broad Cross-Section Cross-Country Look', Journal of Productivity Analysis 6 (1995), pp. 117-135.

White, H., 'A Heteroscedasticity-Consistent Covariance Matrix Estimator and a Direct Test for Heteroscedasticity', Econometrica 48 (1980), pp. 817-838.

Wood, A., North-South Trade, Employment and Inequality, Clarendon Press, Oxford, 1994.

, 'How Trade Hurt Unskilled Workers', Journal of Economic Perspectives 9 (1995), pp. 57-80. 


\section{APPENDIX A1}

\section{Data Description}

All data except the Spanish, data on long-term interest rates and data on technical change are taken from the OECD's ISDB database. Employment data contain the number of employees, excluding the self-employed. Wages include all payments made to wage and salary earners ${ }^{1}$, including social security payments. Both sectoral and national prices are also calculated from the ISDB database, via value added at market prices (with 1985 as a base year). Technically speaking, it would have been preferable to use value added at factor costs to construct price levels for this would exclude taxes and subsidies which may differ between countries. Only for GreatBritain value added was available at factor costs in the database (and subsequently used). All variables are expressed in national price levels.

All interest data are taken from the International Financial Statistics Yearbook published by the IMF (from 1990 and 1995 publications). The long-term government bond yield was taken as a proxy for the long-term interest rate ${ }^{2}$.

As a proxy of technical change, $R \& D$ expenditures are used ${ }^{3}$. These data are taken from the OECD's ANBERD database.

For Spain, employment, wage and sectoral price levels are calculated from the OECD's STAN database. Spanish employment figures do include the selfemployed. R\&D data are again taken from ANBERD, whereas both national price levels (the GDP deflator) and the interest rate data are taken from the International Financial Statistics Yearbook. All import data (for all countries) come from the OECD's BITRA database.

The sectors included in the analysis are the 2-digit ISIC sectors 31 through 39 , which define total manufacturing (ISIC sector 30). In the remainder, we will denote these sectors by means of an abbreviation. These abbreviations are:

\footnotetext{
1. Which also do not include the self-employed.

2. As suggested by the IMF itself, cf. the International Financial Statistics Yearbook 1995 (1995), pp. $x v-x v i$.

3. One may claim that because $R \& D$ personnel is included in the labour variable our regression results are biased (since we are also using $R \& D$ expenditures as a separate variable). However, this only means that there may be some collinearity between the R\&D and labour variable (which is justified from a theoretical point of view). Regression results do not become biased because of collinearity. See also section 3 of the main text.
} 
Table A.1.1 Sector classification and abbreviations.

\begin{tabular}{||lll||}
\hline ISIC code & Abbreviation & Sector description \\
30 & ZMT & \\
31 & ZLF & Total manufacturing \\
32 & ZLX & Food, drink and tobacco \\
33 & ZOW & Textiles, footwear and leather \\
34 & ZOP & Wood, cork and furniture \\
35 & Z35 & Paper and printing \\
36 & ZOG & Chemicals \\
37 & ZMB & Stone, clay and glass \\
38 & Z38 & Basic metals \\
39 & ZOO & Fabricated metal products, machinery and equipment \\
\hline
\end{tabular}

Furthermore, the following country codes will be used from here onwards:

Table A.1.2 Country codes.

\begin{tabular}{||ll||}
\hline Country & Country code \\
USA & USA \\
Former West-Germany & DEU \\
France & FRA \\
Great-Britain & GBR \\
Netherlands & NLD \\
Italy & ITA \\
Spain & ESP \\
\hline
\end{tabular}

In the regression analyses three sectors were dropped because of missing R\&D data: the Dutch and Italian wood, cork and furniture sector and the Dutch other manufacturing industries. 


\section{APPENDIX A2}

\section{Growth Rates}

Below, an overview of mean growth rates of the variables included in our model can be found. The period over which means are taken is motivated by the estimation periods of the 'final' regressions depicted in appendix B3. The table is divided into two parts: first, the results for the US, Germany, France and GreatBritain are shown, whereafter the results for the Netherlands, Spain and Italy follow.

Table A.2.1 Mean growth rates for the US, Germany, France and Great-Britain (sample period according to appendix B3, variable definitions according to the regression equation and appendix B1).

\begin{tabular}{|c|c|c|c|c|}
\hline Sector & $\mathbf{L}$ & $\mathbf{W}$ & $\mathbf{P}$ & $\mathbf{A}$ \\
\hline USAZ35 & 0.0063 & 0.0179 & -0.0019 & 0.0455 \\
\hline USAZ38 & -0.0036 & 0.0062 & -0.0156 & 0.0126 \\
\hline USAZLX & -0.0199 & -0.0145 & -0.0265 & 0.032 \\
\hline USAZOG & -0.0134 & -0.008 & -0.0076 & 0.0105 \\
\hline USAZOP & 0.0108 & 0.0179 & 0.0052 & 0.0522 \\
\hline USAZLF & -0.002 & 0.0048 & 0.0023 & 0.0294 \\
\hline USAZMB & -0.0286 & -0.0222 & 0.0015 & -0.0049 \\
\hline USAZMT & -0.0045 & 0.0047 & -0.0085 & 0.0187 \\
\hline USAZOO & -0.0067 & 0.0018 & -0.0048 & 0.0041 \\
\hline USAZOW & 0 & 0.0046 & -0.0056 & 0.0209 \\
\hline DEUZMT & -0.008 & 0.0138 & -0.0026 & 0.042 \\
\hline DEUZ35 & 0.0034 & 0.0248 & 0.0026 & 0.0308 \\
\hline DEUZ38 & 0.0018 & 0.026 & -0.0012 & 0.0519 \\
\hline DEUZLF & -0.0034 & 0.0099 & -0.0038 & 0.0651 \\
\hline DEUZLX & -0.0435 & -0.0222 & -0.008 & 0.0583 \\
\hline DEUZMB & -0.0157 & -0.0003 & -0.0135 & 0.0026 \\
\hline DEUZOG & -0.0178 & 0.0009 & -0.0064 & 0.0684 \\
\hline DEUZOP & -0.0031 & 0.0153 & 0.0025 & 0.0789 \\
\hline DEUZOW & -0.006 & 0.0091 & 0.0086 & 0.4281 \\
\hline FRAZLF & 0.0037 & 0.017 & -0.0049 & 0.073 \\
\hline FRAZLX & -0.0393 & -0.0195 & -0.0019 & -0.0056 \\
\hline FRAZMB & -0.0257 & -0.0219 & -0.0196 & 0.0791 \\
\hline FRAZOG & -0.0244 & -0.0037 & 0.001 & 0.0215 \\
\hline
\end{tabular}




\begin{tabular}{|c|c|c|c|c|}
\hline Sector & $\mathbf{L}$ & W & $\mathbf{P}$ & $\mathbf{A}$ \\
\hline FRAZOO & -0.0053 & 0.0034 & 0.0008 & 0.0752 \\
\hline FRAZOP & -0.0016 & 0.018 & 0.0087 & 0.0227 \\
\hline GBRZ38 & -0.0244 & -0.0067 & -0.0073 & -0.1341 \\
\hline GBRZLF & -0.0212 & 0.0046 & -0.0047 & -0.0886 \\
\hline GBRZMT & -0.0283 & -0.0047 & -0.0061 & 0.0127 \\
\hline GBRZOG & -0.0333 & -0.009 & 0.0032 & -0.0369 \\
\hline GBRZOO & -0.0253 & 0.0209 & 0.0359 & -0.0019 \\
\hline GBRZOW & -0.0152 & -0.0077 & -0.0007 & -0.0019 \\
\hline GBRZOP & -0.0101 & 0.0107 & 0.006 & -0.0022 \\
\hline GBRZMB & -0.0571 & -0.0457 & -0.0206 & -0.0914 \\
\hline FRAZ35 & -0.006 & 0.003 & -0.0079 & 0.0458 \\
\hline FRAZ38 & -0.0149 & 0.0004 & -0.0035 & 0.0507 \\
\hline FRAZOW & -0.0235 & -0.0082 & -0.0051 & 0.0779 \\
\hline DEUZOO & -0.0216 & 0.0013 & -0.0002 & 0.0243 \\
\hline FRAZMT & -0.0095 & -0.0005 & -0.0007 & 0.044 \\
\hline GBRZ35 & -0.007 & 0.0264 & -0.021 & 0.0692 \\
\hline GBRZLX & -0.0376 & -0.0053 & 0 & -0.0537 \\
\hline DEURATE1 & 0.0696 & SMPL: 74-93 & & \\
\hline USARATE & 0.3643 & $74-93$ & & \\
\hline DEURATE2 & 0.0734 & $74-92$ & & \\
\hline GBRRATE1 & 0.259 & $74-92$ & & \\
\hline FRARATE1 & 0.5437 & $74-91$ & & \\
\hline GBRRATE2 & 0.0303 & $74-89$ & & \\
\hline FRARATE2 & -0.2758 & $80-91$ & & \\
\hline DEURATE3 & 0.0447 & $81-92$ & & \\
\hline GBRRATE3 & 0.4908 & $86-92$ & & \\
\hline FRARATE3 & 0.1147 & $86-91$ & & \\
\hline
\end{tabular}


Table A.2.2 Mean growth rates for the Netherlands, Spain and Italy (sample period according to appendix B3, variable definitions according to the regression equation and appendix B1).

\begin{tabular}{|c|c|c|c|c|}
\hline Sector & $\mathbf{L}$ & W & $\mathbf{P}$ & $\mathbf{A}$ \\
\hline NLDZMT & -0.0123 & 0.0028 & -0.0095 & 0.0187 \\
\hline NLDZOP & -0.0006 & 0.0134 & -0.0064 & 0.0126 \\
\hline NLDZLF & -0.0115 & 0.0042 & -0.0099 & 0.0415 \\
\hline NLDZLX & -0.0495 & -0.0353 & -0.0054 & -0.0074 \\
\hline NLDZMB & -0.0139 & -0.0015 & -0.0083 & 0.0234 \\
\hline NLDZ35 & 0.0026 & 0.0137 & -0.0052 & 0.0223 \\
\hline NLDZ38 & -0.0098 & -0.0007 & 0.0007 & 0.019 \\
\hline NLDZOG & -0.0135 & 0.0036 & 0.0084 & 0.0585 \\
\hline ESPZ35 & -0.0184 & -0.0056 & -0.0019 & 0.0824 \\
\hline ESPZ38 & -0.0001 & -0.0026 & -0.0026 & 0.1399 \\
\hline ESPZLF & -0.0085 & 0.0092 & -0.0188 & 0.111 \\
\hline ESPZLX & -0.0333 & -0.0361 & -0.0088 & 0.1199 \\
\hline ESPZMB & -0.0399 & -0.0323 & -0.0339 & 0.0173 \\
\hline ESPZMT & -0.0138 & -0.0078 & -0.0089 & 0.1139 \\
\hline ESPZOG & -0.0221 & -0.0159 & 0.0005 & 0.047 \\
\hline ESPZOO & -0.0129 & 0.0017 & -0.0489 & 0.5407 \\
\hline ESPZOP & 0.0099 & 0.023 & 0.0089 & 0.1171 \\
\hline ESPZOW & -0.0189 & -0.0173 & -0.0047 & 0.5935 \\
\hline ITAZ35 & -0.0051 & 0.0038 & -0.0466 & 0.0545 \\
\hline ITAZLF & -0.0121 & 0.0002 & -0.0191 & 0.0967 \\
\hline ITAZMB & -0.0369 & -0.0257 & -0.0519 & 0.0418 \\
\hline ITAZMT & -0.0153 & -0.0036 & -0.0256 & 0.0752 \\
\hline ITAZOG & -0.0086 & 0.0059 & -0.0037 & 0.1213 \\
\hline ITAZOP & -0.0094 & 0.0034 & -0.0158 & 0.0204 \\
\hline ITAZOO & -0.0161 & 0.0002 & 0.0044 & 0.2288 \\
\hline ITAZOW & -0.0211 & -0.0102 & -0.0148 & -0.0148 \\
\hline ITAZ38 & -0.025 & -0.01 & -0.0245 & 0.056 \\
\hline ITAZLX & -0.0197 & -0.0107 & -0.0176 & 0.3001 \\
\hline NLDRATE1 & -0.292 & SMPL: 74-93 & & \\
\hline ITARATE1 & 0.5662 & 74-94 & & \\
\hline ESPRATE & -9.5446 & 80-91 & & \\
\hline
\end{tabular}




\begin{tabular}{|l|r|r|r|l||}
\hline \hline Sector & & & & \\
\hline \hline ITARATE2 & 0.1873 & SMPL: $81-94$ & & \\
\hline NLDRATE2 & 0.0287 & $81-93$ & & \\
\hline
\end{tabular}


APPENDIX B1

Basic regressions/Testing for structural breaks

Regression equation is:

$$
\begin{aligned}
w_{i j t}= & \gamma_{0 i j}+\gamma_{1 i j} p_{i j t}+\gamma_{2 i j} r_{j t}+\gamma_{3 i j} A_{i j t}+\gamma_{4 i j} L_{i j t}+\varepsilon_{i j t} \\
& \text { where, } i=\text { sector subscript; } \\
& j=\text { country subscript; }
\end{aligned}
$$

w, $P, r, A, L$ are defined cf. the basic perfect competition model

$\varepsilon=$ random disturbance term.

Sector and country classifications are defined in table A.1.1 and A.1.2 (SECTOR). The estimation period is given under SMPL. T indicates the
value of the T-statistic for the null hypothesis that $\gamma_{\mathrm{k}}=0$ ( $\left.\mathrm{k}=0.44\right)$. Chow tests are carried out in (roughly) 1981 and 1985 (exact dates are given value of the T-statistic for the null hypothesis that $\gamma_{\mathrm{k}}=0 \quad(\mathrm{k}=0 . .4)$. Chow tests are carried out in (roughly) 1981 and 1985 (exact dates are given
in the main text, pp. 8-9). $\mathbf{p}_{\mathrm{m}}$ denotes the $\mathrm{p}$-value of the corresponding F-statistic $\mathbf{F}_{\mathrm{m}}(\mathrm{m}=81,85)$. $\overrightarrow{\boldsymbol{R}}^{2}$ denotes the value of the adjusted $\mathrm{R}^{2}$ statistic,
whereas DW contains the value of the Durbin-Watson statistic for (first-order) serial correlation in the disturbance term $\varepsilon_{i j t}$. All regression equations whe estimated with a heteroscedasticity-consistent covariance matrix. If an entry cannot be calculated, it is denoted by $\star * \star *$.

$\begin{array}{lll}\text { SECTOR } & \text { SMPL } & \gamma_{0} \\ \text { DEUZ35 } & 74-92 & 0.02 \\ \text { DEUZ38 } & 74-92 & 0.02 \\ \text { DEUZLF } & 74-92 & 0.01 \\ \text { DEUZLX } & 74-92 & 0.02 \\ \text { DEUZMB } & 74-92 & 0.02 \\ \text { DEUZMT } & 74-93 & 0.02 \\ \text { DEUZOG } & 74-92 & 0.02 \\ \text { DEUZOO } & 74-92 & 0.03 \\ \text { DEUZOP } & 74-92 & 0.02 \\ \text { DEUZOW } & 74-92 & 0.02 \\ \text { FRAZ35 } & 74-91 & 0.03 \\ \text { FRAZ38 } & 74-91 & 0.02 \\ \text { FRAZLF } & 74-91 & 0.01 \\ \text { FRAZLX } & 74-91 & 0.02 \\ \text { FRAZMB } & 74-91 & 0.00 \\ \text { FRAZMT } & 74-91 & 0.01 \\ \text { FRAZOG } & 74-91 & 0.02 \\ \text { FRAZOO } & 74-91 & 0.00 \\ \text { FRAZOP } & 74-91 & 0.02 \\ \text { FRAZOW } & 74-91 & 0.02 \\ \text { GBRZ35 } & 74-92 & 0.01 \\ \text { GBRZ38 } & 74-92 & 0.00 \\ \text { GBRZLF } & 74-92 & 0.01 \\ \text { GBRZLX } & 74-92 & 0.04 \\ \text { GBRZMB } & 74-89 & 0.03 \\ \text { GBRZMT } & 74-92 & 0.02 \\ \text { GBRZOG } & 74-92 & 0.01\end{array}$

$\mathbf{T}_{\gamma 0} \quad \gamma_{3}$

$\begin{array}{ll}(3.76) & 0.13 \\ (3.38) & 0.02\end{array}$

$\begin{array}{ll}(4.80) & 0.02 \\ (3.05) & -0.00\end{array}$

$\begin{array}{ll}(3.35) & -0.04 \\ (4.55) & 0.08\end{array}$

$\begin{array}{ll}(4.55) & 0.08 \\ (3.41) & 0.02\end{array}$

$\begin{array}{ll}2.74) & -0.00\end{array}$

$\begin{array}{ll}(3.34) & 0.00 \\ (2.83) & 0.00\end{array}$

$\begin{array}{ll}(1.73) & -0.08\end{array}$

$\begin{array}{ll}(1.19) & 0.04\end{array}$

$(0.02) \quad 0.03$

$\begin{array}{ll}(2.02) & 0.20\end{array}$

$\begin{array}{ll}(1.40) & 0.03\end{array}$

$\begin{array}{ll}(8.09) & -0.21\end{array}$

$\begin{array}{ll}(2.15) & -0.03 \\ (1.00) & 0.16\end{array}$

$(0.11) \quad-0.01$

$\begin{array}{ll}(0.34) & 0.07 \\ (1.71) & 0.30\end{array}$

$\begin{array}{ll}(0.63) & 0.42\end{array}$

$\begin{array}{ll}(1.18) & 0.04 \\ (1.29) & 0.35\end{array}$
$\begin{array}{ll}\mathbf{T}_{\gamma 3} & \gamma_{2}\end{array}$

$\begin{array}{ll}(1.82) & 0.03\end{array}$

$\begin{array}{ll}(1.35) & 0.03 \\ (1.03) & 0.00\end{array}$

$\begin{array}{ll}(0.41) & 0.01 \\ (0.63) & 0.03\end{array}$

$\begin{array}{ll}(1.94) & 0.01\end{array}$

$\begin{array}{ll}(1.71) & 0.02 \\ (1.70) & -0.01\end{array}$

$\begin{array}{ll}(0.17) & 0.01 \\ (0.14) & 0.02\end{array}$

$\begin{array}{ll}(0.33) & -0.00 \\ (0.74) & 0.00\end{array}$

$\begin{array}{ll}(0.37) & 0.00\end{array}$

$\begin{array}{ll}(0.18) & 0.00 \\ (0.38) & 0.00\end{array}$

$\begin{array}{ll}(1.18) & 0.00 \\ (0.32) & -0.01\end{array}$

$\begin{array}{ll}(0.32) & -0.01 \\ (0.54) & 0.00\end{array}$

$\begin{array}{lll}(4.10) & -0.00\end{array}$

$\begin{array}{ll}(0.82) & 0.00 \\ (0.82) & -0.00\end{array}$

$\begin{array}{ll}(0.37) & -0.00 \\ (0.35) & -0.00\end{array}$

(1.01) $\quad 0.00$

$\begin{array}{ll}(2.85) & 0.00\end{array}$
$\mathbf{T}_{\gamma 2} \quad \gamma_{1}$

$\begin{array}{ll}0.83) & 0.19\end{array}$

$(0.79) \quad-0.15$

$\begin{array}{ll}(0.79) & -0.15 \\ (1.06) & -0.38 \\ (1.01) & 0.04\end{array}$

$\begin{array}{ll}(1.01) & 0.04 \\ (0.28) & -0.22\end{array}$

$\begin{array}{ll}0.76) & 0.14 \\ 0.90) & -0.14\end{array}$

$(0.53) \quad-0.09$

$\begin{array}{ll}(0.52) & 0.13 \\ (1.13) & -0.27\end{array}$

\begin{tabular}{ll}
$0.87) \quad-0.22$ \\
\hline
\end{tabular}

$\begin{array}{ll}(0.93) & 0.13 \\ (1.83) & -0.54\end{array}$

$\begin{array}{ll}(3.43) & 0.36\end{array}$

$(3.29) \quad 0.18$
$(0.56) \quad 0.44$

$\begin{array}{ll}(0.56) & 0.44 \\ (0.23) & 0.22\end{array}$

$\begin{array}{ll}(0.33) & 0.17 \\ (0.17) & 0.06\end{array}$

$\begin{array}{ll}(0.13) & 0.17 \\ (0.29) & 0.06\end{array}$

$(0.83) \quad 0.12$

$\begin{array}{ll}(0.06) & 0.29 \\ (0.19) & 0.25\end{array}$
$\begin{array}{ll}\mathbf{T}_{\gamma 1} & \gamma_{4}\end{array}$

$(0.70) \quad 0.74$

$\begin{array}{ll}(0.55) & 1.02 \\ (1.55) & 1.25 \\ (0.90) & 1.01\end{array}$

$\begin{array}{ll}(0.90) & 1.01 \\ (3.61) & 1.06\end{array}$

$\begin{array}{ll}(1.04) & 1.07 \\ (0.20) & 1.24\end{array}$

$\begin{array}{ll}(2.08) & 0.98\end{array}$

$\begin{array}{ll}(0.88) & 0.81 \\ (0.49) & 1.29\end{array}$

$\begin{array}{ll}(0.66) & 1.59 \\ (0.23) & 1.43\end{array}$

$(0.50) \quad 0.43$

$\begin{array}{ll}(1.39) & 1.16 \\ (0.71) & 0.93\end{array}$

$\begin{array}{ll}(2.92) & 1.30 \\ (1.81) & 0.72\end{array}$

$\begin{array}{ll}(0.33) & 0.19 \\ (2.29) & 0.17\end{array}$

$\begin{array}{ll}(2.80) & 0.71\end{array}$

$\begin{array}{ll}(.10) & 0.47 \\ (0.78) & 0.33\end{array}$

$\left(\begin{array}{ll}(0.58) & -0.15 \\ (1.15) & 0.67\end{array}\right.$

$\begin{array}{ll}(0.74) & 0.44\end{array}$

$\begin{array}{ll}(1.21) & 0.67 \\ (2.22) & 0.31\end{array}$
$\begin{array}{llllll}\vec{R}^{2} & \text { DW } & \mathbf{F}_{81} & \mathbf{P}_{81} & \mathbf{F}_{85} & \mathbf{P}_{85}\end{array}$

$\begin{array}{lllllllll}(3.40) & 0.57 & 1.74 & 1.1 & 0.42 & 0.4 & 0.84\end{array}$ $\begin{array}{lllllll}(8.01) & 0.66 & 1.29 & 3.0 & 0.07 & 0.3 & 0.88 \\ (12.66) & 0.84 & 1.96 & 0.8 & 0.57 & 0.8 & 0.57\end{array}$ $\begin{array}{lllllll}(7.59) & 0.82 & 1.25 & 0.9 & 0.51 & 0.1 & 1.00\end{array}$ $\begin{array}{lllllll}(3.99) & 0.63 & 2.25 & 0.5 & 0.79 & 0.6 & 0.71\end{array}$ $\begin{array}{lllllll}(12.12) & 0.78 & 1.40 & 2.8 & 0.08 & 0.2 & 0.94\end{array}$ $\begin{array}{lllllll}(12.73) & 0.65 & 1.83 & 5.6 & 0.01 & 0.4 & 0.85\end{array}$ $\begin{array}{lllllll}(4.04) & 0.60 & 1.52 & 1.1 & 0.41 & 0.3 & 0.91 \\ (11.80) & 0.73 & 2.44 & 0.7 & 0.66 & 0.4 & 0.83\end{array}$ $\begin{array}{lllllll}(1.64) & 0.14 & 1.14 & 16.7 & 0.00 & 2.8 & 0.10\end{array}$ $\begin{array}{llllllll}(1.42) & -0.49 & 1.09 & 12.4 & .00 & 2.8 & 0.10 \\ (0.47) & -0.20 & 1.11 & 3.4 & 0 & 0.06 & 0.6 & 0.73\end{array}$ $\begin{array}{lllllll}(2.67) & 0.29 & 1.50 & 1.6 & 0.28 & 0.3 & 0.90\end{array}$ $\begin{array}{lllllll}(0.94) & 0.21 & 2.64 & 0.1 & 0.99 & 0.5 & 0.77 \\ (3.42) & 0.62 & 1.05 & 9.9 & 0.00 & 5.7 & 0.02\end{array}$ $\begin{array}{lllllll}(3.14) & 0.33 & 2.11 & 3.4 & 0.06 & 0.7 & 0.64\end{array}$ $\begin{array}{llllllll}(0.90) & 0.81 & 2.29 & 2.1 & 0.37 & 1.9 & 0.19\end{array}$ $\begin{array}{lllllll}(6.05) & 0.33 & 1.83 & 4.2 & 0.04 & 0.3 & 0.92 \\ (2.29) & 0.20 & 2.42 & 1.6 & 0.25 & 3.6 & 0.05\end{array}$ $\begin{array}{lllllll}(1.25) & -0.00 & 1.64 & 3.1 & 0.07 & 1.7 & 0.24\end{array}$

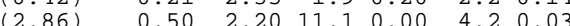
$\begin{array}{llllllll}(1.57) & -0.09 & 1.35 & 1.9 & 0.23 & * * * * * * *\end{array}$ $\begin{array}{lllllll}(3.39) & 0.28 & 2.01 & 2.9 & 0.08 & 2.8 & 0.08 \\ (1.01) & 0.52 & 1.12 & 1.1 & 0.44 & 2.0 & 0.17\end{array}$ 
SECTOR SMPL

GBRZOO 74-92 -0.00 $\begin{array}{lll}\text { GBRZOP } & 74-92 & 0.02\end{array}$

USAZ38 74-93

\begin{tabular}{ll} 
USAZLF & $74-93$ \\
\hline USAZIX & $74-93$
\end{tabular}

USAZMT 74-93

USAZOP 74-93

$\begin{array}{lll}\text { USAZOW } & 74-93 & 0.01\end{array}$

$\begin{array}{lll}\text { ESPZ35 } & 80-91 & 0.02 \\ \text { ESPZ38 } & 80-91 & -0.01\end{array}$

$\begin{array}{lll}\text { ESPZLF } & 80-91 & 0.01 \\ \text { ESPZLX } & 80-91 & 0.01\end{array}$

ESPZMB $\quad 80-91-0.01$

$\begin{array}{lll}\text { ESPZMT } & 80-91 & 0.01 \\ \text { ESPZOG } & 80-91 & -0.00\end{array}$

$\begin{array}{lll} & 0.02\end{array}$

$\begin{array}{lll}\text { ESPZOP } & 80-91 & 0.01 \\ \text { ESPZOW } & 80-91 & -0.01\end{array}$

$\begin{array}{lll}\text { ITAZ35 } & 74-94 & 0.02\end{array}$

$\begin{array}{lll}\text { ITA238 } & 74-94 & 0.02\end{array}$

ITAZLX $\quad 74-94$

$\begin{array}{ll}\text { ITAZMB } & 74-94 \\ \text { ITAZMT } & 74-94\end{array}$

$\begin{array}{lll}\text { ITAZOO } & 74-94 & 0.02 \\ & 0.02\end{array}$

$\begin{array}{lll}\text { ITAZOP } & 74-94 & 0.01 \\ \text { NLDZ35 } & 81-93 & 0.01\end{array}$

$\begin{array}{lll}\text { NLDL235 } & 81-93 & 0.01 \\ \text { NLDZ38 } & 81-93 & 0.01\end{array}$

$\begin{array}{lll}\text { NLDZLF } & 74-93 & 0.01 \\ \text { NLDZLX } & 74-93 & -0.00\end{array}$

$\begin{array}{lll}\text { NLD ZMB } & 74-93 & 0.01\end{array}$

$\begin{array}{lll}\text { NLD ZMT } & 74-93 & 0.01 \\ \text { NLD ZOG } & 81-93 & 0.01\end{array}$
$(0.27) \quad 0.10$

$(2.02)$

$\begin{array}{ll}(1.87) & 0.06 \\ (1.73) & 0.08\end{array}$

$\begin{array}{ll}(1.73) & 0.08 \\ (2.56) & 0.02\end{array}$

\begin{tabular}{ll}
$(1.86) \quad 0.04$ \\
\hline
\end{tabular}

$\begin{array}{ll}(2.01) & 0.04 \\ (2.55) & 0.04 \\ (12.06) & 0.04\end{array}$

$(2.38) \quad 0.06$

(2.11) 0.02

$\begin{array}{ll}(3.21) & -0.03 \\ (0.59) & 0.02\end{array}$

$\begin{array}{ll}(1.13) & 0.06 \\ (0.19) & -0.05\end{array}$

$(0.88) \quad 0.01$

$\begin{array}{ll}(0.72) & 0.02 \\ (0.13) & 0.05\end{array}$

$\begin{array}{ll}(2.02) & 0.01 \\ (0.67) & 0.01\end{array}$

$\begin{array}{ll}(2.69) & 0.06 \\ (3.49) & 0.01\end{array}$

$\begin{array}{ll}(4.66) & -0.03 \\ (1.29) & -0.00\end{array}$

$\begin{array}{ll}(1.00) & -0.00 \\ (3.32) & 0.04\end{array}$

$(2.25) \quad 0.00$

$(2.72) \quad-0.01$

$\begin{array}{ll}2.62) & -0.07 \\ (1.57) & -0.00\end{array}$

$\begin{array}{ll}(1.69) & 0.00 \\ (0.22) & -0.02\end{array}$

$\begin{array}{ll}0.95) & 0.14\end{array}$

$\begin{array}{ll}(2.22) & 0.10 \\ (2.32) & -0.02\end{array}$ $\begin{array}{ll}(1.73) & -0.01 \\ (0.81) & 0.00\end{array}$

$(0.94)-0.00$

$\begin{array}{ll}(0.62) & -0.00 \\ (1.26) & -0.00\end{array}$

$\begin{array}{ll}(0.85) & -0.00 \\ (0.75) & -0.00\end{array}$

$\begin{array}{ll}(1.23) & -0.00 \\ (1.39) & -0.00\end{array}$

$\begin{array}{ll}(0.53) & -0.00 \\ (1.00) & -0.00\end{array}$

$(3.10) \quad 0.00$

$\begin{array}{ll}(1.81) & -0.00\end{array}$

$\begin{array}{ll}(0.57) & 0.00 \\ (1.11) & 0.00\end{array}$

$\begin{array}{ll}(1.18) & 0.00 \\ (0.38) & -0.00 \\ (0.77) & -0.00\end{array}$

$(0.93) \quad 0.00$

$(0.09) \quad 0.00$

$\begin{array}{ll}(0.06) & 0.00 \\ (0.58) & 0.00\end{array}$

$\begin{array}{ll}(0.38) & 0.00 \\ (0.69) & 0.01\end{array}$

$\begin{array}{ll}(0.09) & 0.00 \\ (1.21) & 0.01 \\ (0.14) & 0.01\end{array}$

$\begin{array}{ll}(0.08) & 0.00\end{array}$

$(0.54) \quad-0.00$

$\begin{array}{ll}(2.25) & 0.00 \\ (1.49) & -0.00 \\ (1.29) & -0.01\end{array}$

$\begin{array}{ll}(1.29) & -0.01 \\ (0.59) & 0.00\end{array}$

$\begin{array}{ll}\mathbf{T}_{\gamma 2} & \gamma_{1} \\ (1.41) & 0.71 \\ (2.04) & 0.43 \\ (0.35) & 0.19 \\ (2.12) & 0.06 \\ (1.19) & 0.01 \\ (1.96) & -0.11 \\ (1.01) & 0.17 \\ (1.97) & 0.06 \\ (1.37) & -0.03 \\ (0.65) & -0.01 \\ (0.04) & -0.05 \\ (1.65) & -0.01 \\ (1.99) & 0.13 \\ (2.67) & 0.16 \\ (0.03) & 0.06 \\ (3.95) & 0.25 \\ (0.73) & -0.02 \\ (1.11) & 0.13 \\ (0.22) & 0.39 \\ (0.02) & 0.32 \\ (0.52) & 0.13 \\ (1.68) & -0.05 \\ (0.59) & 0.32 \\ (0.26) & 0.11 \\ (2.19) & 0.39 \\ (1.44) & 0.45 \\ (1.09) & 0.30 \\ (0.37) & 0.05 \\ (1.07) & 0.44 \\ (1.65) & -0.02 \\ (4.31) & 0.06 \\ (3.44) & -0.07 \\ (0.71) & 0.08 \\ (0.53) & 0.67 \\ (2.84) & -0.10 \\ (1.19) & 0.28 \\ (3.93) & 0.09 \\ (1.20) & 0.02 \\ (0.75) & 0.60 \\ (0.88) & 0.10\end{array}$

(2.18) $\quad 0.77$

$\begin{array}{ll}(1.41) & 0.76 \\ (1.01) & 0.82\end{array}$

$\begin{array}{ll}(1.04) & 0.88 \\ (1.17) & 0.77\end{array}$

$\begin{array}{ll}(1.79) & 1.05\end{array}$

$\begin{array}{ll}(0.15) & 0.94 \\ (0.07) & 1.00\end{array}$

$(0.49) \quad 0.94$

$\begin{array}{ll}(2.05) & 0.99 \\ (3.59) & 0.96\end{array}$

$\begin{array}{ll}(0.25) & 1.10\end{array}$

$\begin{array}{ll}(0.71) & 0.37 \\ (0.11) & 0.89\end{array}$

$\begin{array}{ll}(1.18) & 1.04 \\ (2.35) & 0.90\end{array}$

$\begin{array}{ll}(4.23) & 0.79\end{array}$

$\begin{array}{ll}(0.41) & 0.69\end{array}$

$\begin{array}{ll}(0.95) & 1.07 \\ (3.66) & 1.05\end{array}$

$\begin{array}{ll}(3.66) & 1.05 \\ (2.77) & 1.10\end{array}$

$\begin{array}{ll}(1.56) & 0.76 \\ (1.07) & 0.93\end{array}$

$\begin{array}{ll}(2.87) & 1.00 \\ (0.32) & 0.91\end{array}$

$(2.54) \quad 0.96$

(1.60) 1.15

(1.24) 0.71

$\begin{array}{ll}(0.13) & 0.89\end{array}$

$\begin{array}{ll}(8.57) & 0.60 \\ (0.69) & 1.03\end{array}$
$\mathbf{T}_{\gamma 4}$

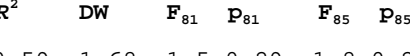

$\begin{array}{llllllll}(3.22) & 0.59 & 1.68 & 1.5 & 0.29 & 1.8 & 0.22 \\ (5.72) & 0.28 & 1.83 & 0.9 & 0.52 & 0.7 & 0.63\end{array}$ $\begin{array}{lllllll}(5.72) & 0.53 & 2.27 & 1.4 & 0.32 & 0.7 & 0.66 \\ (6.34) & 0.75 & 2.18 & \star \star \star \star \star \star & 0.4 & 0.85 \\ (9.02) & 0.89 & 1.50 & * \star \star * * & 0.8 & 0.59\end{array}$

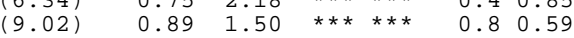
$\begin{array}{llllllll}(4.42) & 0.60 & 2.16 & * \star * & * * * & 0.5 & 0.76 \\ (31.89) & 0.95 & 1.73 & * * * * * * & 1.2 & 0.37\end{array}$ $\begin{array}{lllllll}(16.36) & 0.92 & 1.69 & * * \star * * * & 1.6 & 0.25 \\ (12.60) & 0.90 & 2.04 & * * \star * * * & 0.3 & 0.88\end{array}$ $\begin{array}{lllll}0.88 & 2.04 & 5 * * * * & 0.1 & 1.00\end{array}$ $\begin{array}{lllllll}(7.38) & 0.84 & 2.00 & * * * * * * & 0.3 & 0.91 \\ (6.70) & 0.69 & 2.08 & * * * * * & 0.2 & 0.94\end{array}$ $\begin{array}{lllllll}(24.18) & 0.98 & 2.08 & * * * * * * & 0.4 & 0.87\end{array}$

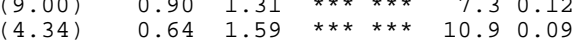
$\begin{array}{llllllll}(0.96) & -0.02 & 1.55 & * * * * * * & 1.1 & 0.54\end{array}$ $\begin{array}{lllllll}(6.06) & 0.72 & 1.90 & * * * * * * & 2.5 & 0.31\end{array}$ $\begin{array}{lllllll}(6.69) & 0.78 & 1.16 & * * * * * * & 4.4 & 0.20\end{array}$ $\begin{array}{lllllll}(9.96) & 0.88 & 2.15 & * \star * & * * * & 2.7 & 0.29 \\ (6.32) & 0.62 & 0.91 & * * * * * * & 0.7 & 0.68\end{array}$ $(7.48) \quad 0.85 \quad 1.55 \quad * * * * * * \quad 1.00 .57$ (3.48) $\quad 0.73 \quad 1.50 \quad * * * * * * \quad 15.1 \quad 0.06$ $\begin{array}{lllllll}(6.56) & 0.59 & 1.83 & 0.7 & 0.67 & 0.7 & 0.63\end{array}$ $\begin{array}{lllllll}(6.82) & 0.57 & 2.25 & 4.4 & 0.02 & 0.9 & 0.49 \\ (2.77) & 0.34 & 2.34 & 1.0 & 0.47 & 1.6 & 0.24\end{array}$ $\begin{array}{llllll}0.34 & 2.04 & 9.2 & 0.00 & 0.2 & 0.97 \\ 0.59 & .92 & .20 & 0.35 & 0.2 & 0.94\end{array}$ $\begin{array}{llllllll}(5.68) & 0.66 & 1.87 & 1.4 & 0.31 & 0.5 & 0.74\end{array}$ $\begin{array}{lllllll}(5.46) & 0.66 & 1.68 & 2.4 & 0.10 & 1.3 & 0.33 \\ (6.65) & 0.75 & 2.22 & 1.7 & 0.21 & 0.6 & 0.71\end{array}$ $\begin{array}{lllllll}(7.64) & 0.53 & 1.82 & 0.3 & 0.88 & 0.3 & 0.88\end{array}$

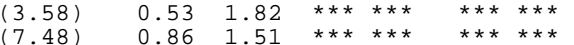
$\begin{array}{lllllll}(2.91) & 0.05 & 1.60 & 0.3 & 0.89 & 1.3 & 0.34\end{array}$ $\begin{array}{lllllll}(5.65) & 0.73 & 1.78 & 1.8 & 0.20 & 1.1 & 0.42 \\ (1.91) & 0.54 & 1.38 & 2.5 & 0.10 & 0.3 & 0.89\end{array}$ $\begin{array}{lllllll}(1.91) & 0.54 & 1.38 & 2.5 & 0.20 & 1.11 & 0.42\end{array}$ $\begin{array}{lllllll}(5.45) & 0.56 & 1.26 & 1.7 & 0.22 & 0.3 & 0.89 \\ (7.23) & 0.96 & 1.40 & * * * & * * * & * * * & * * * \\ (5.86) & 0.72 & 2.00 & 2.0 & 0.17 & 2.7 & 0.08\end{array}$ 
APPENDIX B2

Testing the significance of the constant term Regression equation identical to appendix B1. When found to be significant, structural breaks are taken into account. All equations are

$\begin{array}{lll}\text { SECTOR } & \text { SMPL } & \gamma_{0} \\ \text { DEUZ35 } & 74-92 & 0.02 \\ \text { DEUZ38 } & 74-92 & 0.02 \\ \text { DEUZLF } & 74-92 & 0.01 \\ \text { DEUZLX } & 74-92 & 0.02 \\ \text { DEUZMB } & 74-92 & 0.02 \\ \text { DEUZMT } & 74-93 & 0.02 \\ \text { DEUZOG } & 74-92 & 0.02 \\ \text { DEUZOO } & 81-92 & 0.02 \\ \text { DEUZOP } & 74-92 & 0.02 \\ \text { DEUZOW } & 74-92 & 0.02 \\ \text { FRAZ35 } & 80-91 & -0.0 \\ \text { FRAZ38 } & 80-91 & -0.01 \\ \text { FRAZLF } & 74-91 & 0.01 \\ \text { FRAZLX } & 74-91 & 0.02 \\ \text { FRAZMB } & 74-91 & 0.00 \\ \text { FRAZMT } & 86-91 & 0.03 \\ \text { FRAZOG } & 74-91 & 0.02 \\ \text { FRAZOO } & 74-91 & 0.00 \\ \text { FRAZOP } & 74-91 & 0.02 \\ \text { FRAZOW } & 80-91 & 0.01 \\ \text { GBRZ35 } & 74-92 & 0.01 \\ \text { GBRZ35 } & 86-92 & 0.03 \\ \text { GBRZ38 } & 74-92 & 0.00 \\ \text { GBRZLF } & 74-92 & 0.01 \\ \text { GBRZLX } & 86-92 & 0.00 \\ \text { GBRZMB } & 74-89 & 0.03 \\ \text { GBRZMT } & 74-92 & 0.02 \\ \text { GBRZOG } & 74-92 & 0.01 \\ \text { GBRZOO } & 74-92 & -0.00 \\ \text { GBRZOP } & 74-92 & 0.02 \\ \text { GBRZOW } & 74-92 & 0.00 \\ \text { USAZ35 } & 74-93 & 0.01 \\ \text { USAZ38 } & 74-93 & 0.01 \\ \text { USAZLF } & 74-93 & 0.01 \\ \text { USAZLX } & 74-93 & 0.01 \\ \text { USAZMB } & 74-93 & 0.01 \\ \text { USAZMT } & 74-93 & 0.01 \\ \text { USAZOG } & 74-93 & 0.01 \\ \text { USAZOO } & 74-93 & 0.01 \\ \text { USAZOP } & 74-93 & 0.01 \\ \text { ISA } & & \end{array}$

$\begin{array}{ll}\mathbf{T}_{\gamma 0} & \gamma_{3} \\ (3.76) & 0.13 \\ (3.38) & 0.02 \\ (4.80) & 0.02 \\ (3.05) & -0.00 \\ (3.35) & -0.04 \\ (4.55) & 0.08 \\ (3.41) & 0.02 \\ (5.40) & 0.01 \\ (3.34) & 0.00 \\ (2.83) & 0.00 \\ (0.33) & 0.16 \\ (1.80) & 0.42 \\ (1.19) & 0.04 \\ (1.32) & 0.01 \\ (0.02) & 0.03 \\ (2.10) & -0.36 \\ (1.40) & 0.03 \\ (0.14) & 0.01 \\ (8.09) & -0.21 \\ (1.57) & -0.00 \\ (1.00) & 0.16 \\ (1.10) & 0.20 \\ (0.11) & -0.01 \\ (0.34) & 0.07 \\ (0.06) & -0.16 \\ (0.63) & 0.42 \\ (1.18) & 0.04 \\ (1.29) & 0.35 \\ (0.27) & 0.10 \\ (2.02) & 0.10 \\ (0.47) & 0.06 \\ (1.85) & 0.08 \\ (1.73) & 0.08 \\ (2.56) & 0.02 \\ (1.86) & 0.04 \\ (2.01) & 0.04 \\ (2.55) & 0.04 \\ (1.06) & 0.04 \\ (2.38) & 0.06 \\ (1.92) & -0.02 \\ & \end{array}$

$\begin{array}{ll}\mathbf{T}_{\gamma 3} & \gamma_{2} \\ (1.82) & 0.03 \\ (0.35) & 0.01 \\ (1.03) & 0.00 \\ (0.41) & 0.01 \\ (0.63) & 0.03 \\ (1.94) & 0.01 \\ (0.71) & 0.02 \\ (0.09) & 0.01 \\ (0.17) & 0.01 \\ (0.14) & 0.02 \\ (0.96) & -0.01 \\ (3.41) & -0.00 \\ (0.37) & 0.00 \\ (0.18) & 0.00 \\ (0.38) & 0.00 \\ (1.42) & 0.01 \\ (0.32) & -0.01 \\ (0.54) & 0.00 \\ (4.10) & -0.00 \\ (0.03) & -0.00 \\ (0.82) & -0.00 \\ (0.91) & -0.02 \\ (0.37) & -0.00 \\ (0.35) & -0.00 \\ (0.26) & -0.02 \\ (1.01) & 0.00 \\ (0.24) & -0.00 \\ (2.85) & 0.00 \\ (1.19) & -0.01 \\ (1.73) & -0.01 \\ (0.81) & 0.00 \\ (0.94) & -0.00 \\ (1.20) & -0.00 \\ (0.62) & -0.00 \\ (1.26) & -0.00 \\ (0.85) & -0.00 \\ (0.75) & -000 \\ (1.23) & -0.00 \\ (1.39) & -0.00 \\ (0.53) & -0.00 \\ & \end{array}$

$\begin{array}{ll}\mathbf{T}_{\gamma 2} & \gamma_{1} \\ (2.37) & 0.12 \\ (0.83) & 0.19 \\ (0.36) & -0.08 \\ (0.79) & -0.15 \\ (2.18) & 0.38 \\ (1.06) & -0.22 \\ (1.01) & 0.04 \\ (1.04) & -0.51 \\ (0.76) & 0.14 \\ (0.90) & -0.14 \\ (3.83) & 0.03 \\ (1.05) & -0.56 \\ (1.13) & -0.27 \\ (0.87) & -0.22 \\ (0.93) & 0.13 \\ (1.05) & -0.81 \\ (3.43) & 0.36 \\ (1.55) & 0.04 \\ (6.29) & 0.18 \\ (1.90) & 0.17 \\ (0.23) & 0.22 \\ (4.24) & 0.45 \\ (0.33) & 0.17 \\ (0.17) & 0.06 \\ (79.52) & 1.84 \\ (0.83) & 0.12 \\ (0.06) & 0.29 \\ (0.19) & 0.25 \\ (1.41) & 0.71 \\ (2.04) & 0.43 \\ (0.35) & 0.19 \\ (2.12) & 0.06 \\ (1.19) & 0.01 \\ (1.96) & -0.11 \\ (1.01) & 0.17 \\ (1.97) & 0.06 \\ (1.37) & -0.03 \\ (0.65) & -0.01 \\ (0.04) & -0.05 \\ (1.65) & -0.01 \\ & \end{array}$

$\begin{array}{ll}\mathbf{T}_{\gamma 1} & \gamma_{4} \\ (0.70) & 0.74 \\ (0.55) & 1.02 \\ (1.55) & 1.25 \\ (0.90) & 1.01 \\ (3.61) & 1.06 \\ (1.04) & 1.07 \\ (0.20) & 1.24 \\ (2.77) & 0.71 \\ (0.88) & 0.81 \\ (0.49) & 1.29 \\ (0.28) & 0.58 \\ (3.15) & 0.73 \\ (0.50) & 0.43 \\ (1.39) & 1.16 \\ (0.71) & 0.93 \\ (7.27) & 1.46 \\ (1.81) & 0.72 \\ (0.33) & 0.19 \\ (2.29) & 0.17 \\ (1.22) & 0.81 \\ (1.10) & 0.47 \\ (2.53) & -0.37 \\ (0.78) & 0.33 \\ (0.58) & -0.15 \\ (3.95) & 0.17 \\ (0.74) & 0.44 \\ (1.21) & 0.67 \\ (2.22) & 0.31 \\ (4.72) & -0.07 \\ (2.18) & 0.77 \\ (1.41) & 0.76 \\ (1.01) & 0.82 \\ (0.04) & 0.88 \\ (1.65) & 0.77 \\ (1.17) & 1.11 \\ (1.79) & 1.05 \\ (0.15) & 0.94 \\ (0.07) & 1.00 \\ (0.49) & 0.94 \\ (0.04) & 1.01 \\ & \end{array}$

\begin{tabular}{lrl}
$\mathbf{T}_{\gamma 4}$ & \multicolumn{1}{l}{$\vec{R}^{2}$} & \multicolumn{1}{l}{ DW } \\
$(3.40)$ & 0.57 & 1.74 \\
$(8.01)$ & 0.66 & 1.29 \\
$(12.66)$ & 0.84 & 1.96 \\
$(7.59)$ & 0.82 & 1.25 \\
$(3.99)$ & 0.63 & 2.25 \\
$(12.12)$ & 0.78 & 1.40 \\
$(8.17)$ & 0.77 & 1.81 \\
$(5.49)$ & 0.87 & 2.61 \\
$(4.04)$ & 0.60 & 1.52 \\
$(11.80)$ & 0.73 & 2.44 \\
$(2.85)$ & 0.35 & 2.74 \\
$(3.96)$ & 0.82 & 2.63 \\
$(0.47)$ & -0.20 & 1.11 \\
$(2.67)$ & 0.29 & 1.50 \\
$(0.94)$ & 0.21 & 2.64 \\
$(3.01)$ & 0.92 & 3.27 \\
$(3.14)$ & 0.33 & 2.11 \\
$(0.42)$ & -0.19 & 1.76 \\
$(0.90)$ & 0.81 & 2.29 \\
$(12.31)$ & 0.75 & 2.58 \\
$(2.29)$ & 0.20 & 2.42 \\
$(0.40)$ & 0.44 & 3.05 \\
$(1.25)$ & -0.00 & 1.64 \\
$(0.42)$ & -0.21 & 2.35 \\
$(4.34)$ & 0.98 & 0.72 \\
$(1.57)$ & -0.09 & 1.35 \\
$(3.39)$ & 0.28 & 2.01 \\
$(1.01)$ & 0.52 & 1.12 \\
$(0.56)$ & 0.59 & 1.68 \\
$(3.22)$ & 0.28 & 1.83 \\
$(5.72)$ & 0.53 & 2.27 \\
$(6.34)$ & 0.75 & 2.18 \\
$(9.02)$ & 0.89 & 1.50 \\
$(4.42)$ & 0.60 & 2.16 \\
$(3.89)$ & 0.95 & 1.73 \\
$(16.36)$ & 0.92 & 1.69 \\
$(12.60)$ & 0.90 & 2.04 \\
$(9.28)$ & 0.88 & 2.52 \\
$(7.38)$ & 0.84 & 2.00 \\
$(6.70)$ & 0.69 & 2.08 \\
& &
\end{tabular}




\begin{tabular}{|c|c|c|c|c|c|c|c|c|c|c|c|c|c|}
\hline SECTOR & SMPL & $\gamma_{0}$ & $\mathbf{T}_{\gamma 0}$ & $\gamma_{3}$ & $\mathbf{T}_{\gamma^{3}}$ & $\gamma_{2}$ & $\mathbf{T}_{\gamma 2}$ & $\gamma_{1}$ & $\mathbf{T}_{\gamma 1}$ & $\gamma_{4}$ & $\mathbf{T}_{\gamma 4}$ & $\bar{R}^{2}$ & DW \\
\hline USAZOW & $4-93$ & 0.01 & $(2.11)$ & 0.02 & $(1.00)$ & -0.00 & $(1.99)$ & 0.13 & $(2.05)$ & 0.99 & $(24.18)$ & 0.98 & 2. \\
\hline ESPZ35 & & .02 & $(3.21)$ & -0.03 & $(3.10)$ & 0.00 & $(2.67)$ & 0.16 & $(3.59)$ & 0.96 & $(9.00)$ & 0.90 & \\
\hline ESPZ38 & $0-$ & -0.01 & $(0.59)$ & 0.02 & $(0.31)$ & 0.00 & $(0.03)$ & 0.06 & $(0.25)$ & 1.10 & $(4.34)$ & 0.64 & \\
\hline ESPZLF & $80-91$ & 0.01 & $(1.13)$ & 0.06 & $(0.66)$ & -0.00 & $(3.95)$ & 0.25 & $(0.71)$ & 0.37 & $(0.96)$ & -0.02 & \\
\hline ESPZLX & $80-91$ & -0.00 & $(0.19)$ & -0.05 & $(1.81)$ & -0.00 & $(0.73)$ & -0.02 & $(0.11)$ & 0.89 & $(6.06)$ & 0.72 & \\
\hline ESP ZMB & $80-91$ & 0.01 & $(0.88)$ & 0.01 & $(0.40)$ & -0.00 & $(1.11)$ & 0.13 & $(1.18)$ & 1.04 & $(4.50)$ & 0.75 & \\
\hline ESP ZMT & $0-$ & 0.01 & 10.7 & 0.02 & $(0.57)$ & 0.00 & 10. & 0.39 & $2.35)$ & 0.90 & $(6.69)$ & 0.78 & \\
\hline ESPZOG & $0-$ & -0.00 & $(0.13)$ & 0.05 & $(1.11)$ & 0.00 & $(0.02)$ & 0.32 & $(4.23)$ & 0.79 & $(9.96)$ & 0.88 & \\
\hline ESPZOO & $80-91$ & 0.02 & $(0.60)$ & 0.01 & $(1.18)$ & 0.00 & $(0.52)$ & 0.1 & $(0.69)$ & & & & \\
\hline ESPZOP & $80-91$ & 0.01 & $(2.02)$ & 0.01 & $(0.38)$ & -0.00 & $(1.68)$ & -0.05 & $(0.41)$ & & $(7.48)$ & & \\
\hline ESPZOW & $80-91$ & -0.01 & $(0.67)$ & 0.01 & $(0.77)$ & -0.00 & $(0.59)$ & 0.32 & $(1.48)$ & & $(3.48)$ & & \\
\hline & & 0.02 & & & & & & & & & & & \\
\hline ITAZ & $81-9$ & 0.0 & $(2.33)$ & 0.08 & $(1.64)$ & 0.00 & $(0.28)$ & 0.29 & $(1.34)$ & 1.00 & $(7.14)$ & 0.77 & 32 \\
\hline ITAZLF & $\begin{array}{l}74-94 \\
81-94\end{array}$ & 0.03 & $(4.66)$ & -0.03 & $(1.20)$ & 0.00 & $(1.44)$ & 0.45 & $(2.77)$ & 1. & $(6.82)$ & & 34 \\
\hline ITAZLX & $81-94$ & 0.01 & $(0.84)$ & -0.00 & $(0.20)$ & -0.00 & $(0.80)$ & 0.17 & $(0.72)$ & 0. & $(4.15)$ & 0.34 & \\
\hline $\begin{array}{l}\text { ITAZMB B } \\
\text { ITAZMMT }\end{array}$ & $\begin{array}{l}74-94 \\
74-94\end{array}$ & 0.01 & $\left(\begin{array}{l}(1.00) \\
(3.32)\end{array}\right.$ & -0.00 & $\begin{array}{l}(0.06) \\
(0.58)\end{array}$ & 0.00 & $(0.37)$ & 0.05 & $\begin{array}{r}(1.07) \\
(2.87\end{array}$ & 0.93 & $(2.69)$ & 0.59 & $\begin{array}{l}2 . \\
1 .\end{array}$ \\
\hline $\begin{array}{l}\text { ITAZMT } \\
\text { ITAZOG }\end{array}$ & $\begin{array}{l}74-94 \\
74-94\end{array}$ & $\begin{array}{l}0.02 \\
0.02\end{array}$ & $\begin{array}{r}(3.32) \\
(2.25)\end{array}$ & 0.04 & $\begin{array}{l}(0.58) \\
(0.38)\end{array}$ & 0.00 & $\begin{array}{l}(1.07) \\
(1.65)\end{array}$ & $\begin{array}{l}0.44 \\
-0.02\end{array}$ & $\begin{array}{r}(2.87) \\
(0.32\end{array}$ & $\begin{array}{l}1.00 \\
0.91\end{array}$ & $\begin{array}{l}(5.68) \\
(5.46)\end{array}$ & 0.66 & 1.68 \\
\hline ITAZOO & $14-94$ & 0.02 & $\begin{array}{r}(2.25) \\
(2.72)\end{array}$ & -0 & $(0.68)$ & 0.01 & $\begin{array}{l}(1.65) \\
(4.31)\end{array}$ & 0.02 & $\begin{array}{r}(0.32) \\
(2.54)\end{array}$ & $\begin{array}{r}0.91 \\
0.96\end{array}$ & $\begin{array}{l}(5.46) \\
(6.65)\end{array}$ & 0.06 & $\begin{array}{l}1.68 \\
2.22\end{array}$ \\
\hline ITAZOP & $74-94$ & 0 & $(2.49)$ & 0.00 & $(0.09)$ & & $(3.44)$ & -0.07 & $(1.16)$ & 0. & $(7.64)$ & 0.53 & $\begin{array}{l}2.2 \\
1.8\end{array}$ \\
\hline NLDZ 35 & $1-93$ & .0 & $(2.62)$ & -0.07 & $(1.21)$ & 0.01 & $(0.71)$ & 0.08 & $(1.60)$ & 1.15 & $(3.58)$ & 0.53 & 1.82 \\
\hline 8 & & ( & $(1.57)$ & -0.00 & $(0.14)$ & 0.0 & $(0.53)$ & & $(4.24)$ & 0. & $(7.48)$ & 0.86 & \\
\hline 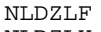 & 7 & & ) & & $.08)$ & & $.84)$ & 10 & $1.24)$ & & $(2.91)$ & & \\
\hline 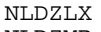 & 7 & 0.00 & 0.22 & 2 & $(0.54)$ & $D$ & .19) & 0.28 & $1.62)$ & & ) & & \\
\hline ILD2 & & & & & $.25)$ & & & 0. & 1.71) & 0 . & ) & & \\
\hline JLD & 7 & & 2.42 & . & 9) & 0 & 1.2 & 0. & 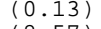 & 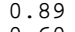 & $(5$ & & \\
\hline NLDZOG & 8 & .0 & 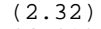 & 0.02 & $(1.29)$ & -0.01 & $(0.75$ & 0.6 & $(8.57)$ & 0.6 & $(7.23)$ & 0.96 & \\
\hline JLDZOP & $74-93$ & 0.02 & $(4.29)$ & -0.01 & $(0.59)$ & 0.00 & $(0.88)$ & 0.10 & $(0.69)$ & 1.03 & $(5.86)$ & 0.72 & $.0 c$ \\
\hline
\end{tabular}


APPENDIX B3

Including constant term

Regression equation identical to appendix B1. Whenever present, structural breaks and significant constant terms are taken into account. All restriction put forward in the main text. Pas denotes the corresponding p-value. All other definitions according to appendix B1 and B2.

$\begin{array}{lll}\text { SECTOR } & \text { SMPL } & \gamma_{0} \\ \text { DEUZ35 } & 74-92 & 0.02 \\ \text { DEUZ38 } & 74-92 & 0.02 \\ \text { DEUZLF } & 74-92 & 0.01 \\ \text { DEUZLX } & 74-92 & 0.02 \\ \text { DEUZMB } & 74-92 & 0.02 \\ \text { DEUZMT } & 74-93 & 0.02 \\ \text { DEUZOG } & 74-92 & 0.02 \\ \text { DEUZOO } & 81-92 & 0.02 \\ \text { DEUZOP } & 74-92 & 0.02 \\ \text { DEUZOW } & 74-92 & 0.02 \\ \text { FRAZMT } & 86-91 & 0.03 \\ \text { FRAZOP } & 74-91 & 0.02 \\ \text { GBRZOP } & 74-92 & 0.02 \\ \text { USAZLF } & 74-93 & 0.01 \\ \text { USAZMB } & 74-93 & 0.01 \\ \text { USAZMT } & 74-93 & 0.01 \\ \text { USAZOO } & 74-93 & 0.01 \\ \text { USAZOW } & 74-93 & 0.01 \\ \text { ESPZ35 } & 80-91 & 0.02 \\ \text { ESPZOP } & 80-91 & 0.01 \\ \text { ITAZ35 } & 74-94 & 0.02 \\ \text { ITAZ38 } & 81-94 & 0.02 \\ \text { ITAZLF } & 74-94 & 0.03 \\ \text { ITAZMT } & 74-94 & 0.02 \\ \text { ITAZOG } & 74-94 & 0.02 \\ \text { ITAZOP } & 74-94 & 0.01 \\ \text { NLDZ35 } & 81-93 & 0.01 \\ \text { NLDZMT } & 74-93 & 0.01 \\ \text { NLDZOG } & 81-93 & 0.01 \\ \text { NLDZOP } & 74-93 & 0.02\end{array}$

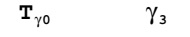

$\mathbf{T}_{\gamma 3}$ $(3.76) \quad 0.13$ $\begin{array}{ll}(3.38) & 0.02 \\ (4.80) & 0.02\end{array}$ $(3.05) \quad-0.00$ $\begin{array}{ll}(3.55) & 0.08\end{array}$ (3.41) 0.02 $\begin{array}{ll}(5.40) & 0.01 \\ (3.34) & 0.00\end{array}$ (2.83) 0.00 $(2.10) \quad-0.36$ $(2.02) \quad 0.10$ $(2.01) \quad 0.04$ $(2.55) \quad 0.04$ $\begin{array}{ll}(2.38) & 0.06 \\ (2.11) & 0.02\end{array}$ $\begin{array}{ll}(2.11) & 0.02 \\ (3.21) & -0.03\end{array}$ (2.02) $\quad 0.01$ $(2.69) \quad 0.06$ (2.33) 0.08 $\begin{array}{ll}(4.66) & -0.08\end{array}$ $\begin{array}{ll}(2.25) & 0.00\end{array}$ $(2.49) \quad 0.00$ $(2.62) \quad-0.07$ $(2.22) \quad 0.10$ $\begin{array}{ll}(2.32) & -0.02 \\ (4.29) & -0.01\end{array}$

$\begin{array}{ll}\mathbf{T}_{\gamma 3} & \gamma_{2} \\ (1.82) & 0.03 \\ (0.35) & 0.01 \\ (1.03) & 0.00 \\ (0.41) & 0.01 \\ (0.63) & 0.03 \\ (1.94) & 0.01 \\ (0.71) & 0.02 \\ (0.09) & 0.01 \\ (0.17) & 0.01 \\ (0.14) & 0.02 \\ (1.42) & 0.01 \\ (4.10) & -0.00 \\ (1.73) & -0.01 \\ (0.62) & -0.00 \\ (0.85) & -0.00 \\ (0.75) & -0.00 \\ (1.39) & -0.00 \\ (1.00) & -0.00 \\ (3.10) & 0.00 \\ (0.38) & -0.00 \\ (0.93) & 0.00 \\ (1.64) & 0.00 \\ (1.20) & 0.00 \\ (0.58) & 0.00 \\ (0.38) & 0.00 \\ (0.09) & 0.00 \\ (1.21) & 0.01 \\ (1.49) & -0.00 \\ (1.29) & -0.01 \\ (0.59) & 0.00\end{array}$

$\begin{array}{ll}\mathbf{T}_{\gamma 1} & \gamma_{4}\end{array}$

$\begin{array}{ll}(0.70) & 0.74\end{array}$

$\begin{array}{ll}(0.55) & 1.02 \\ (1.55) & 1.25\end{array}$

$(0.90) \quad 1.01$

$\begin{array}{ll}(1.04) & 1.07\end{array}$

$\begin{array}{ll}(0.20) & 1.24 \\ (2.77) & 0.71\end{array}$

$(0.88) \quad 0.81$

$\begin{array}{ll}(0.49) & 1.29 \\ (7.27) & 1.46\end{array}$

$\begin{array}{ll}(2.29) & 0.17 \\ (2.18) & 0.77\end{array}$

$\begin{array}{ll}(1.65) & 0.77\end{array}$

$\begin{array}{ll}(1.79) & 1.05 \\ (0.15) & 0.94\end{array}$

$\begin{array}{ll}(0.49) & 0.94 \\ (2.05) & 0.99\end{array}$

$(3.59) \quad 0.96$

$\begin{array}{ll}(0.95) & 1.07\end{array}$

$\begin{array}{ll}(2.87) & 1.00 \\ (0.32) & 0.91\end{array}$

(1.16) 0.81

$(1.60) \quad 1.15$

$\begin{array}{ll}(0.13) & 0.89 \\ (8.57) & 0.60 \\ (0.69) & 1.03\end{array}$
$\mathbf{T}_{\gamma}$

$\begin{array}{lllll}(3.40) & 0.57 & 1.74 & 25.4 & 0.00\end{array}$ $\begin{array}{lllll}(8.01) & 0.66 & 1.29 & 4.7 & 0.03 \\ (12.66) & 0.84 & 1.96 & 346.3 & 0.00\end{array}$

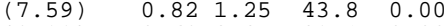
$\begin{array}{lllll}(3.99) & 0.63 & 2.25 & 29.1 & 0.00 \\ (12.12) & 0.78 & 1.40 & 31.3 & 0.00\end{array}$ $\begin{array}{lllll}(8.17) & 0.77 & 1.81 & 21.6 & 0.00\end{array}$ $\begin{array}{lllll}(4.04) & 0.60 & 1.52 & 26.4 & 0.00\end{array}$ $\begin{array}{lllll}(11.80) & 0.73 & 2.44 & 16.4 & 0.00 \\ (3.01) & 0.92 & 3.27 & 254.1 & 0.00 \\ (3.90) & 0.81 & 2.29 & 108.6 & 0.00\end{array}$ $\begin{array}{llll}0.81 & 2.29 & 108.6 & 0.00\end{array}$ $\begin{array}{lllll}(3.22) & 0.28 & 1.83 & 8.8 & 0.00 \\ (4.42) & 0.60 & 2.16 & 264.7 & 0.00\end{array}$ $\begin{array}{lllll}(16.36) & 0.92 & 1.69 & 707.2 & 0.00\end{array}$ $\begin{array}{lllll}(12.60) & 0.90 & 2.04 & 29.9 & 0.00\end{array}$ $\begin{array}{lllll}(24.18) & 0.98 & 2.08 & 185.7 & 0.000\end{array}$ $\begin{array}{lllll}(9.00) & 0.90 & 1.31 & 351.2 & 0.00\end{array}$ $\begin{array}{lllll}(6.56) & 0.59 & 1.83 & 63.8 & 0.00\end{array}$ $\begin{array}{lllll}(7.14) & 0.77 & 2.32 & 321.0 & 0.00\end{array}$ $\begin{array}{lllll}(5.68) & 0.66 & 1.87 & 13.3 & 0.00\end{array}$ $\begin{array}{lllll}(7.64) & 0.63 & 1.68 & 204.1 & 0.00\end{array}$ $\begin{array}{llllll}(3.58) & 0.53 & 1.82 & 198.8 & 0.00 \\ (5.45) & 0.56 & 1.26 & 46.7 & 0.00\end{array}$ $\begin{array}{lllll}(5.45) & 0.56 & 1.26 & 46.7 & 0.00 \\ (7.23) & 0.96 & 1.40 & 36.2 & 0.00\end{array}$ 


\section{Excluding constant term ${ }^{4}$}

Regression equation identical to appendix B1, with $\gamma_{0}=0$. Whenever present, structural breaks are taken into account. All equations are estimated with a heteroscedasticity-consistent covariance matrix. All other definitions according to appendix B1 and B2.

\begin{tabular}{|c|c|c|c|c|c|c|c|c|c|c|c|c|c|}
\hline SECTOR & SMPL & $\gamma_{3}$ & $\mathbf{T}_{\gamma 3}$ & $\gamma_{2}$ & $\mathbf{T}_{\gamma^{2}}$ & $\gamma_{1}$ & $\mathbf{T}_{\gamma 1}$ & $\gamma_{4}$ & $\mathbf{T}_{\gamma^{4}}$ & $\bar{R}^{2}$ & DW & $F_{\text {rest }}$ & $\mathrm{P}_{\text {rest }}$ \\
\hline FRAZ35 & $80-91$ & 0.13 & $(1.40)$ & -0.01 & $(4.22)$ & 0.02 & $(0.23)$ & 0.60 & $(2.54)$ & 0.42 & 2.74 & 89.9 & 0.00 \\
\hline FRAZ38 & $80-91$ & 0.26 & $(6.44)$ & -0.00 & $(0.60)$ & -0.52 & $(2.38)$ & 0.89 & $(7.11)$ & 0.80 & 2.33 & 49.1 & 0.00 \\
\hline FRAZLF & 74-91 & 0.08 & $(0.93)$ & 0.00 & $(1.25)$ & -0.36 & $(0.74)$ & 0.79 & $(0.89)$ & -0.17 & 1.22 & 7.7 & 0.01 \\
\hline FRAZLX & $74-$ & -0.03 & 10. & 0.0 & $(0.67)$ & -0.22 & $(1$ & 0.57 & $(5.98)$ & 0 & 9 & .3 & 0.00 \\
\hline $\begin{array}{l}\text { FRAZMB } \\
\text { FRAZOG }\end{array}$ & $\begin{array}{l}74-91 \\
74-91\end{array}$ & 0.03 & $(0.90)$ & 0.00 & $(1.20)$ & 0.13 & $(0.75)$ & $\begin{array}{l}0.92 \\
0.38\end{array}$ & $(3.36)$ & 26 & 2.64 & 24.3 & .00 \\
\hline $\begin{array}{l}\text { FRAZOG } \\
\text { FRAZOO }\end{array}$ & $\begin{array}{l}74-91 \\
74-91\end{array}$ & $\begin{array}{l}0.13 \\
0.01\end{array}$ & $\begin{array}{l}(1.41) \\
(0.81)\end{array}$ & $\begin{array}{l}-0.01 \\
0.00\end{array}$ & $\begin{array}{r}(3.33) \\
(1.61)\end{array}$ & $\begin{array}{l}0.50 \\
0.04\end{array}$ & $\begin{array}{r}(2.49) \\
(0.35)\end{array}$ & $\begin{array}{l}0.38 \\
0.17\end{array}$ & $\begin{array}{l}(1.91) \\
(0.47)\end{array}$ & $\begin{array}{r}0.31 \\
-0.11\end{array}$ & $\begin{array}{l}1.80 \\
1.76\end{array}$ & $\begin{array}{l}6.5 \\
73^{2}\end{array}$ & $\begin{array}{l}0.01 \\
0.00\end{array}$ \\
\hline FRAZOW & $80-91$ & 0.01 & $(0.31)$ & -0.00 & $\begin{array}{l}(1.61) \\
(1.81)\end{array}$ & 0.13 & $\begin{array}{l}(0.35) \\
(0.77)\end{array}$ & 0.66 & $\begin{array}{l}(0.47) \\
(4.90)\end{array}$ & $\begin{array}{r}-0.11 \\
0.68\end{array}$ & 1.76 & $\begin{array}{r}73.5 \\
26.7\end{array}$ & $\begin{array}{l}0.00 \\
0.00\end{array}$ \\
\hline GBRZ35 & $86-92$ & 0.44 & $(4.36)$ & -0.03 & $(4.99)$ & 0.14 & $(0.31)$ & -0.89 & $\begin{array}{l}(4.90) \\
(1.70)\end{array}$ & $\begin{array}{l}0.68 \\
0.46\end{array}$ & $\begin{array}{l}1.61 \\
2.48\end{array}$ & & 00 \\
\hline GBRZ38 & $74-92$ & -0.01 & $(0.65)$ & -0.00 & $(0.32)$ & 0.17 & $(0.81)$ & 0.31 & $(1.85)$ & 0.06 & 1.61 & 16.1 & 0 . \\
\hline GBRZLF & & & $(0.10)$ & 0.00 & $(0.41)$ & 0.06 & $(0.63)$ & -0.24 & 10.8 & -0.14 & & 00.8 & \\
\hline GBRZLX & $86-92$ & -0.20 & $(2.93)$ & -0.02 & $(38.92)$ & 1.87 & $(14.68)$ & 0.17 & $(4.98)$ & 0.99 & 0.72 & 44.3 & 0 . \\
\hline GBRZMB & 74 & 0.19 & $(1.15)$ & 0.00 & $(0.61)$ & 0.11 & $(0.71)$ & 0.31 & (1.51) & -0.03 & 1.20 & 34.3 & \\
\hline GBRZMT & & & $(1.54)$ & 0.0 & & 0.24 & $(1.05)$ & 0.3 & 201 & 0.23 & & & \\
\hline GBRZOG & $74-92$ & 36 & $(3.16)$ & 0.00 & $(0.02)$ & 0.26 & $(2.41)$ & 0.14 & $(0.48)$ & 0.51 & 1.07 & 48.9 & 0. \\
\hline GBRZOO & $74-92$ & 9 & $(1.22)$ & -0.01 & & 0.70 & $(4.85)$ & -0.06 & $(0.54)$ & 0.61 & 1.66 & 4 & \\
\hline GBRZOW & 74 & 0.06 & $(0.86)$ & 0.00 & $(0.35)$ & 0.19 & $(1.44)$ & 0.73 & $(6.44)$ & 0.55 & 2.20 & 39.7 & \\
\hline USAZ35 & 74-93 & 0.21 & $(3.59)$ & -0.00 & $(1.38)$ & 0.04 & $(0.60)$ & 0.85 & $(6.03)$ & 0.71 & 2.10 & 227.8 & \\
\hline USAZ38 & 74-93 & 0.14 & $(2.23)$ & -0.00 & $(0.86)$ & -0.21 & $(1.34)$ & 0.80 & $(10.63)$ & 0.87 & 1.28 & & \\
\hline USAZLX & 74-93 & 0.06 & $(2.35)$ & -0.00 & $(3.17)$ & -0.10 & $(1.49)$ & 1.05 & $(22.96)$ & 0.94 & 1.42 & 26 & \\
\hline USAZOG & 74-93 & 0. & $(1.80)$ & -0.00 & & -0.07 & $(0.54)$ & 0.98 & $(9.70)$ & 0.88 & 2.28 & & \\
\hline USAZOP & & 0. & (0. & -0.00 & & 0. & & 1. & & & 1. & & \\
\hline ESPZ38 & $80-91$ & -0.00 & (0. & 0. & & 0. & & 1. & & 0. & 1. & 16.9 & 0.00 \\
\hline ESPZLF & $80-$ & 0.07 & $(0$. & & & 0. & & & & & & & 0.01 \\
\hline ESPZLX & $80-91$ & -0.05 & (2. & -0 . & & -0.02 & 10. & & & & 1. & 50.8 & 0.00 \\
\hline ESP ZMB & $80-$ & 0.03 & (1. & -0.00 & $(1.14)$ & 0.0 & & 0.89 & & 0 . & & 139.4 & 0.00 \\
\hline ESP & 8 & 0 . & & -0 & & & & & & & & & 0.00 \\
\hline ESPZOG & $80-91$ & 0.05 & $(1.76)$ & 0.0 & $(0.39)$ & 0. & $(4.52)$ & 0.79 & $(12.48)$ & 0 . & 2.16 & 93.0 & 0.00 \\
\hline ESP ZOO & $80-91$ & 0.01 & $(1.67)$ & 0.00 & $(0.31)$ & 0.09 & $(0.55)$ & 0.77 & $(5.67)$ & 0 . & 0.91 & 29.6 & 0.00 \\
\hline ESPZOW & $80-91$ & 0.00 & $(0.43)$ & -0.00 & $(0.32)$ & 0.29 & $(1.39)$ & 0.83 & $(3.45)$ & 0.76 & 1.43 & 11.1 & 0.00 \\
\hline ITAZLX & $81-9$ & 0.00 & $(0.55)$ & -0.00 & $(0.59)$ & 0.03 & $(0.25)$ & 0.59 & $(3.22)$ & 0.38 & 1.72 & 68.5 & 0.00 \\
\hline ITA & 74- & 0.00 & $(0.07)$ & 0.00 & $(0.47)$ & 0.0 & $(1.41)$ & 0.75 & $(3.45)$ & 0.57 & 2.75 & 514.8 & 0.00 \\
\hline ITA & $74-$ & 0. & $(0.22)$ & 0.01 & (5. & & $(2.40)$ & 0.75 & $(6.57)$ & 6 & 1. & 686.3 & .00 \\
\hline NLDZ38 & $81-93$ & 0.00 & $(0.13)$ & 0.01 & $(0.80)$ & 0.72 & $(3.16)$ & 0.76 & $(8.50)$ & 0.83 & 1.26 & 1.4 & 0.23 \\
\hline $\begin{array}{l}\text { NLDZLF } \\
\text { NLDZLX }\end{array}$ & $\begin{array}{r}74-93 \\
74-93\end{array}$ & $\begin{array}{l}0.01 \\
-0.02\end{array}$ & $\begin{array}{l}(0.56) \\
(0.53)\end{array}$ & -0.00 & $\begin{array}{l}(1.27) \\
(1.17)\end{array}$ & $\begin{array}{l}-0.10 \\
0.28\end{array}$ & $\begin{array}{l}(1.00) \\
(1.63)\end{array}$ & $\begin{array}{l}0.26 \\
0.68\end{array}$ & $\begin{array}{l}1.57) \\
7.84)\end{array}$ & -0.11 & $\begin{array}{l}1.46 \\
1.78\end{array}$ & $\begin{array}{l}23.4 \\
8.3\end{array}$ & $\begin{array}{l}0.00 \\
0.00\end{array}$ \\
\hline NLDZLX & & & & & $(1.17)$ & 0.28 & $(1.63)$ & 0.68 & $(7.84)$ & 0.74 & 1.78 & 18.3 & \\
\hline
\end{tabular}

4. The Durbin-Watson statistic can in the absence of a constant term in the regression equation, only be regarded as a crude indication of the presence of (first-order) serial correlation. Tests based on a Lagrange Multiplier (LM) approach gave identical results though. 
$\begin{array}{llllllllllllll}\text { SECTOR } & \text { SMPL } & \gamma_{3} & \mathbf{T}_{\gamma 3} & \gamma_{2} & \mathbf{T}_{\gamma 2} & \gamma_{1} & \mathbf{T}_{\gamma 1} & \gamma_{4} & \mathbf{T}_{\gamma 4} & \overrightarrow{\boldsymbol{R}}^{2} & \text { DW } & \mathbf{F}_{\text {rest }} & \mathbf{p}_{\text {rest }}\end{array}$

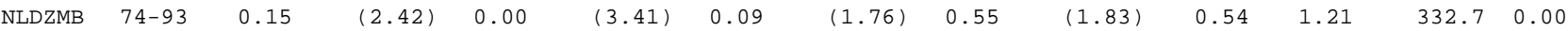


APPENDIX B4

Granger causality tests

Regression equation is

$$
\begin{aligned}
& Y_{i j t}=\delta_{0 i j}+\sum_{p i j} \alpha_{p i j} Y_{i j, t p}+\sum_{q i j} \beta_{q i j} X_{i j, t} q^{+} \varepsilon_{i j t} \\
& \text { where } i=\text { sector subscript, } \\
& \begin{array}{c}
j=\text { country subscript } \\
p, q=\text { predetermined lag orders }(p, q=1 \ldots 3), \\
\varepsilon=\text { random disturbance term. }
\end{array}
\end{aligned}
$$

First it is tested whether labour growth Granger causes wage growth ( $\mathbf{F}_{\text {IW }}$, with corresponding p-value $\mathbf{p}_{\text {Iw }}$ ), whereafter the reverse situation is tested (denoted by $\boldsymbol{F}_{\mathrm{wL}}$, with corresponding p-value $\mathbf{p}_{\mathrm{wL}}$ ).

$\begin{array}{llllll}\text { SECTOR } & \text { SMPL } & \mathbf{F}_{\text {Lw }} & \mathbf{p}_{\text {Iw }} & \mathbf{F}_{\text {wL }} & \mathbf{p}_{\text {wI }} \\ \text { USAZ35 } & 74-94 & 1.67 & 0.22 & 1.12 & 0.38 \\ \text { DEUZ35 } & 74-94 & 1.20 & 0.35 & 3.04 & 0.07 \\ \text { GBRZ35 } & 74-94 & 0.49 & 0.70 & 5.89 & 0.01 \\ \text { NLDZ35 } & 74-94 & 1.01 & 0.42 & 0.19 & 0.90 \\ \text { ESPZ35 } & 74-94 & 0.84 & 0.56 & 0.34 & 0.80 \\ \text { ITAZ35 } & 74-94 & 0.56 & 0.65 & 1.33 & 0.30 \\ \text { USAZ38 } & 74-94 & 0.65 & 0.60 & 0.63 & 0.61 \\ \text { GBRZ38 } & 74-94 & 6.33 & 0.01 & 2.98 & 0.07 \\ \text { NLDZ38 } & 74-94 & 2.09 & 0.15 & 0.64 & 0.60 \\ \text { ESPZ38 } & 74-94 & 0.27 & 0.85 & 0.63 & 0.64 \\ \text { ITAZ38 } & 74-94 & 0.51 & 0.68 & 3.07 & 0.06 \\ \text { USAZLF } & 74-94 & 0.43 & 0.73 & 0.32 & 0.81 \\ \text { DEUZLF } & 74-94 & 1.26 & 0.33 & 0.16 & 0.92 \\ \text { GBRZLF } & 74-94 & 4.73 & 0.02 & 0.42 & 0.74 \\ \text { NLDZLF } & 74-94 & 1.32 & 0.31 & 0.66 & 0.59 \\ \text { ESPZLF } & 74-94 & 1.36 & 0.40 & 0.33 & 0.81 \\ \text { ITAZLF } & 74-94 & 0.59 & 0.63 & 1.06 & 0.40 \\ \text { USAZLX } & 74-94 & 1.70 & 0.22 & 0.57 & 0.64 \\ \text { FRAZLX } & 74-94 & 0.40 & 0.76 & 0.92 & 0.46 \\ \text { DEUZLX } & 74-94 & 2.02 & 0.16 & 0.99 & 0.43 \\ \text { GBRZLX } & 74-94 & 0.59 & 0.64 & 8.04 & 0.00 \\ \text { NLDZLX } & 74-94 & 1.08 & 0.39 & 0.04 & 0.99 \\ \text { ESPZLX } & 74-94 & 4.19 & 0.13 & 10.2 & 0.04 \\ \text { ITAZLX } & 74-94 & 0.40 & 0.75 & 0.80 & 0.51 \\ \text { USAZMB } & 74-94 & 0.62 & 0.61 & 0.64 & 0.60 \\ \text { FRAZMB } & 74-94 & 1.19 & 0.36 & 1.22 & 0.35 \\ \text { DEUZMB } & 74-94 & 0.67 & 0.59 & 0.26 & 0.85 \\ \text { GBRZMB } & 74-94 & 0.17 & 0.92 & 3.75 & 0.05 \\ \text { NLDZMB } & 74-94 & 0.94 & 0.45 & 2.48 & 0.11 \\ \text { ESPZMB } & 74-94 & 0.68 & 0.62 & 0.42 & 0.75 \\ \text { ITAZMB } & 74-94 & 1.15 & 0.36 & 2.66 & 0.09\end{array}$


SECTOR SMPL

USAZMT 74-94

$\begin{array}{ll}\text { GBRZMT } & 74-94 \\ \text { NLDZMT } & 74-94\end{array}$

USAZOG 74-9

DEUZOG 74-94

NLDZOG 74-9

$\begin{array}{ll}\text { ESPZOG } & 74-94 \\ \text { ITAZOG } & 74-94\end{array}$

FRAZOO $74-9$

DEUZOO 74-94

NLDZOO $74-94$

$\begin{array}{ll}\text { ESPZOO } & 74-94 \\ \text { USAZOP } & 74-94\end{array}$

FRAZOP 74-94

DEUZOP $74-94$

NLDZOP 74-94

ESPZOP $74-94$

USAZOW 74-94

DEUZOW 74-94

GBRZOW 74-9

ESPZOW $74-94$

FRAZ35 74-94

DEUZ38 74-94

FRAZLF 74-94

$\begin{array}{ll}\text { FRAZMT } & 74-94 \\ \text { DEUZMT } & 74-94\end{array}$

ESP ZMT $74-94$

$\begin{array}{ll}\text { ITAZOO } & 74-94 \\ \text { GBRZOG } & 74-94\end{array}$

$\begin{array}{llll}\mathbf{F}_{\text {Lw }} & \mathbf{P}_{\text {Iw }} & \mathbf{F}_{\text {wL }} & \mathbf{P}_{w}\end{array}$

$\begin{array}{llll}0.90 & 0.47 & 0.85 & 0.49 \\ 4.29 & 0.03 & 7.87 & 0.00 \\ 2.49 & 0.11 & 0.40 & 0.76\end{array}$

$\begin{array}{llll}0.76 & 0.54 & 3.21 & 0.76 \\ 0.54 & 0.67 & 1.05 & 0.06\end{array}$

$\begin{array}{llll}0.56 & 0.54 & 3.61 & 0.06 \\ 0.38 & 0.77 & 0.40 & 0.41 \\ 0.67 & 0.59 & 0.21 & 0.75 \\ 0.80 & 0.57 & 2.34 & 0.25\end{array}$

$\begin{array}{llll}0.80 & 0.57 & 2.34 & 0.25 \\ 0.32 & 0.81 & 0.50 & 0.69 \\ 0.96 & 0.72 & 0.78 & 0.33\end{array}$

$\begin{array}{llll}0.46 & 0.72 & 1.26 & 0.33 \\ 0.95 & 0.45 & 0.78 & 0.53\end{array}$

$\begin{array}{llll}0.64 & 0.60 & 2.38 & 0.12 \\ 0.64 & 0.75 & 1.89 & 0.18 \\ 0.41 & 0.75\end{array}$

$\begin{array}{llll}0.99 & 0.43 & 1.50 & 0.26 \\ 2.26 & 0.26 & 0.63 & 0.64 \\ 1.66 & 0.22 & 1.12 & 0.38\end{array}$

$\begin{array}{llll}2.26 & 0.26 & 1.50 & 0.26 \\ 1.66 & 0.22 & 1.12 & 0.64 \\ 2.85 & 0.09 & 3.37 & 0.38\end{array}$

$\begin{array}{llll}0.51 & 0.68 & 0.29 & 0.83 \\ 1.96 & 0.17 & 3.07 & 0.07 \\ 6.79 & 0.06 & 0.62 & 0.61\end{array}$

$\begin{array}{llll}3.09 & 0.06 & 0.62 & 0.61 \\ 6.77 & 0.08 & 7.88 & 0.06\end{array}$

$\begin{array}{llll}1.71 & 0.08 & 7.88 & 0.61 \\ 1.11 & 0.38 & 5.75 & 0.01 \\ 1.47 & 0.27 & 1.59 & 0.24 \\ 3.37 & 0.05 & 7.88 & 0.00\end{array}$

$\begin{array}{llll}1.47 & 0.38 & 5.75 & 0.01 \\ 3.37 & 0.05 & 7.59 & 0.24 \\ 0.26 & 0.85 & 1.19 & 0.00 \\ 1.57 & 0.25 & 1.30 & 0.35\end{array}$

$\begin{array}{llll}1.57 & 0.25 & 1.30 & 0.32 \\ 0.33 & 0.81 & 0.43 & 0.75\end{array}$

$\begin{array}{llll}1.35 & 0.30 & 0.52 & 0.68 \\ 2.55 & 0.11 & 0.97 & 0.44 \\ .45 & 0.28 & 0.77 & 0.53\end{array}$

$\begin{array}{llll}1.35 & 0.30 & 0.52 & 0.68 \\ 1.45 & 0.28 & 0.77 & 0.44 \\ 0.69 & 0.57 & 0.78 & 0.53\end{array}$

$\begin{array}{llll}0.69 & 0.57 & 0.78 & 0.53 \\ 0.02 & 1.00 & 2.19 & 0.15 \\ 1.62 & 0.24 & 0.15 & 0.93\end{array}$

$\begin{array}{llll}0.02 & 1.00 & 2.19 & 0.15 \\ 3.11 & 0.06 & 2.54 & 0.10 \\ 0.57 & 0.66 & 0.77 & 0.57 \\ 0.29 & 0.83 & 0.242 & 0.86\end{array}$

$\begin{array}{llll}0.29 & 0.83 & 0.74 & 0.86 \\ 0.29 & 0.83 & 0.22 & 0.88 \\ 0.73 & 0.55 & 2.43 & 0.12\end{array}$ 
Wage growth determines labour growth - final regressions

Regression equation is :

$$
L_{i j t}=\delta_{0 i j}+\delta_{1 i j} p_{i j t}+\delta_{2 i j} r_{j t}+\delta_{3 i j} A_{i j t}+\delta_{4 i j} \omega_{i j t}+\eta_{i j t},
$$

$$
\text { where, } i=\text { sector; }
$$

$w, p, r, A, L$ are defined $c f$. the basic perfect competition model;

$\eta=$ random disturbance term.

\begin{tabular}{|c|c|c|c|c|c|c|c|c|c|c|c|c|c|}
\hline$O R$ & SMPL & $\delta_{0}$ & $\mathbf{T}_{\delta 0}$ & $\delta_{3}$ & $\mathbf{T}_{\delta 3}$ & $\gamma_{2}$ & $\mathbf{T}_{\delta 2}$ & $\delta_{1}$ & $\mathbf{T}_{\delta 1}$ & $\delta_{4}$ & $\mathbf{T}_{\delta 4}$ & $\vec{R}^{2}$ & DW \\
\hline $\begin{array}{l}\text { BRZ35 } \\
\text { BRZMB }\end{array}$ & $\begin{array}{l}74-92 \\
74-89\end{array}$ & $\begin{array}{l}-0.03 \\
-0.09\end{array}$ & $\begin{array}{l}(3.02) \\
(4.32)\end{array}$ & $\begin{array}{l}0.17 \\
-0.51\end{array}$ & $\begin{array}{l}(1.61) \\
(2.39)\end{array}$ & $\begin{array}{l}-0.00 \\
-0.00\end{array}$ & $\begin{array}{l}(0.17) \\
(0.80)\end{array}$ & $\begin{array}{l}-0.04 \\
-0.11\end{array}$ & $\begin{array}{l}(0.27) \\
(0.96)\end{array}$ & $\begin{array}{l}0.29 \\
0.34\end{array}$ & $\begin{array}{l}(1.36) \\
(1.54)\end{array}$ & $\begin{array}{l}0.21 \\
0.01\end{array}$ & $\begin{array}{l}1.76 \\
1.97\end{array}$ \\
\hline
\end{tabular}

Including constant term

Excluding constant term

Regression equation same as above, with $\delta_{o}=0$.

$\begin{array}{llllllllllll}\text { SECTOR } & \text { SMPL } & \delta_{3} & \mathbf{T}_{\delta 3} & \gamma_{2} & \mathbf{T}_{\delta 2} & \delta_{1} & \mathbf{T}_{\delta 1} & \delta_{4} & \mathbf{T}_{\delta 4} & \overrightarrow{\boldsymbol{R}}^{2} & \text { DW } \\ \text { ESPZLX } & 80-91 & 0.04 & (1.77) & -0.00 & (0.23) & 0.06 & (0.41) & 0.91 & (6.28) & 0.73 & 1.45 \\ \text { GBRZLX } & 74-92 & 0.31 & (3.24) & -0.00 & (0.26) & -0.16 & (1.10) & 0.53 & (3.34) & 0.21 & 2.08 \\ \text { ITAZOP } & 74-94 & -0.00 & (0.34) & -0.00 & (1.49) & 0.16 & (3.05) & 0.56 & (3.20) & 0.49 & 1.26\end{array}$


APPENDIX B5

Basic regressions/Testing for structural breaks

Regression equation is:

$$
\begin{gathered}
W_{i j t}=e_{0 i j}+e_{1 a i j} M_{e u i j t}+e_{1 b i j} M_{\text {neuijt }}+e_{2 i j} r_{j t}+e_{3 i j} A_{i j t}+e_{4 i j} L_{i j t}+\psi_{i j t} \\
\text { where, } i=\text { sector subscript; } \\
j=\text { country subscript; }
\end{gathered}
$$

$W, M_{e u}, M_{\text {neu }}, r, A, L$ are defined $c f$. the imperfect competition model;

$\psi=$ random disturbance term.

\begin{tabular}{|c|c|c|c|c|c|c|c|c|c|c|c|c|c|c|c|c|c|c|c|}
\hline SECTOR & SMPL & $e_{0}$ & eo & $\mathbf{e}_{3}$ & $\mathbf{T}_{\mathrm{e} 3}$ & $\mathbf{e}_{2}$ & $T_{\mathrm{e} 2}$ & $e_{1 a}$ & $\mathbf{T}_{\mathrm{e} 1 \mathrm{a}}$ & $e_{1 b}$ & $\mathbf{T}_{\mathbf{e} 1 \mathrm{~b}}$ & $\mathbf{e}_{4}$ & $\mathbf{T}_{\mathrm{e} 4}$ & $\vec{R}^{2}$ & DW & $F_{81}$ & $\mathrm{P}_{81}$ & $\mathbf{F}_{85}$ & $\mathrm{p}_{85}$ \\
\hline DEU & 7 & & $(2$ & 0 & 1 & 0.02 & & 0.00 & & 0 & ( & 0. & & 0 & 1.66 & 2 & 0.42 & 0.7 & 0.67 \\
\hline DEUZ38 & $74-92$ & & $(2.66)$ & 0.03 & $(0.42)$ & 0.01 & $(0.58)$ & 0.01 & 0. & & & 0.96 & & & & & 0.18 & 1.0 & 0.51 \\
\hline $\begin{array}{l}\text { DEUZLF } \\
\text { DFUZTX }\end{array}$ & $\begin{array}{l}74-92 \\
74-99\end{array}$ & 0.01 & & 0.04 & $(1.60)$ & 0.00 & $(0.56)$ & 0.13 & $(1.79)$ & -0.00 & $(0.14)$ & 1.14 & $(10.81)$ & 0.87 & 1.85 & 0.5 & 0.79 & 0.9 & 0.56 \\
\hline $\begin{array}{l}\text { DEUZLX } \\
\text { DEUZMB }\end{array}$ & $\begin{array}{l}74- \\
74-\end{array}$ & $\begin{array}{l}0.01 \\
0.01\end{array}$ & $\begin{array}{l}(1.44) \\
(2.41)\end{array}$ & $\begin{array}{c}0.00 \\
-0.02\end{array}$ & $(0.03)$ & 0.01 & $(0.82)$ & 0.05 & $(0.51)$ & 0.06 & $(1.03)$ & 0.87 & $(8.34)$ & 0.84 & 1.54 & 2.3 & 0.14 & 1.1 & 0.47 \\
\hline $\begin{array}{l}\text { DEUZMMT } \\
\text { DEUZMT }\end{array}$ & $74-92$ & 0.01 & $\begin{array}{r}(2.41) \\
(2.08)\end{array}$ & 0.08 & $\begin{array}{r}(0.36) \\
(1.54)\end{array}$ & 0.02 & $(0.41)$ & -0.08 & $\begin{array}{l}(0.56) \\
(0.74)\end{array}$ & 0.0 & $\begin{array}{r}(0.32) \\
(1.69)\end{array}$ & 1 & $(3.16)$ & 0.52 & 2.66 & 0.7 & 0.64 & 0.3 & 0.93 \\
\hline DEUZOG & $74-92$ & 0.01 & (1) & 0.0 & $(1.45)$ & 0.0 & 10.8 & 0.24 & $(2.48)$ & -0.01 & $(0.53)$ & $\begin{array}{l}0.92 \\
0.87\end{array}$ & $\begin{array}{l}(7.25) \\
(4.25)\end{array}$ & $\begin{array}{l}0.79 \\
0.84\end{array}$ & 1.47 & 3.4 & 0.07 & 2.4 & 0.14 \\
\hline DEUZOO & $74-9$ & 0.03 & .051 & -0.00 & $(1.57)$ & -0.01 & $(0.26)$ & 0.12 & $(1.06)$ & -0.01 & $(0.27)$ & 0.88 & $\begin{array}{r}(4.96) \\
(3.51)\end{array}$ & $\begin{array}{l}0.84 \\
0.59\end{array}$ & $\begin{array}{l}2.31 \\
2.01\end{array}$ & & $\begin{array}{l}0.70 \\
0.06\end{array}$ & 1.3 & 0.38 \\
\hline DEUZOP & $74-92$ & & 1 & -0.00 & .01, & 0.02 & $(1.07)$ & 0.3 & $(4.06)$ & -0.22 & $02)$ & & & $\begin{array}{r}0.59 \\
0.70\end{array}$ & & & 0.06 & & 0.94 \\
\hline DEUZ & & & & 0. & & & & 2 & & & & & & 0 & & 8 & $\begin{array}{l}0.10 \\
0.18\end{array}$ & .5 & 0.30 \\
\hline FRAZ35 & 74 & & ) & -0.19 & (1.52) & .00 & .14) & 0.11 & (1. & & (2 & 0. & $(.75)$ & 70 & $\begin{array}{l}2.02 \\
1.61\end{array}$ & 1 & 0.18 & $\begin{array}{l}1.0 \\
0.5\end{array}$ & $\begin{array}{l}0.26 \\
0.79\end{array}$ \\
\hline FRAZ38 & 74 & 1 & ) & 0.06 & $.26)$ & .00 & 10) & .04 & 10.42 & 0. & $(0.97)$ & 1.2 & 1 & 0.53 & 1.05 & 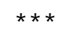 & 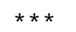 & 0.7 & 0.64 \\
\hline FRAZLF & $74-$ & 1 & 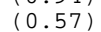 & 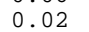 & 1) & & & 0.20 & (1) & -0.05 & 10 & -0.36 & 1) & -0.22 & & $\star \star \star \star$ & $\star \star \star \star$ & 0.3 & 0.89 \\
\hline FRAZLX & 74 & & & 0. & & & & 0.04 & & & & 1.24 & & 0.17 & 1.23 & 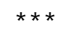 & $\star \star \star \star$ & 0.2 & 0.98 \\
\hline FRAZMB & & & & & & & & & & & & & & & & 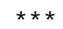 & 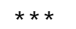 & 6 & 0.28 \\
\hline FRAZMT & 74 & 0. & & & & & & 6 & & & & 1.08 & & & 1.35 & 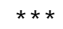 & 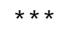 & 1.1 & 0.45 \\
\hline FRAZOG & 74 & & & & & -0.00 & & & & & & & & & 53 & 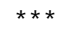 & 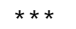 & 0 & 48 \\
\hline & 74 & & & & & & & & & & & & & & & 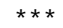 & 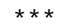 & 6 & 28 \\
\hline FRAZOP & $74-$ & & & -0.16 & & - & & 5 & & & & -0.01 & & 0 & 2.53 & 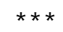 & $\star \star \star \star$ & 0.6 & 0.72 \\
\hline FRA & $74-$ & & & 0.0 & & & & & & & & & & & 68 & $\star \star \star \star$ & $\star \star \star \star$ & 0.2 & 0.98 \\
\hline GBR & 74 & & & & & & & & & & & & & & 2.25 & 1.2 & 0.39 & .8 & 0.05 \\
\hline GBR & & & & & & & & & & & & & & & 1.93 & 2.8 & 0.10 & 1.8 & 0.22 \\
\hline & & & & & & & & & & & & & & & & 4.0 & & 1.8 & 24 \\
\hline GBR2 & 74 & 0 & ) & 0 & 1 & 0.00 & & -0.06 & ic & & & & & & 2 & 6.8 & 01 & 7.8 & 0.01 \\
\hline & 74 & 0. & & & & 0. & & 0 & & & & & & & 1.28 & 3.2 & & & \\
\hline GBR & 74 & 0. & & & & & & & & & & & & & & 2.1 & 18 & 3.9 & 0.05 \\
\hline GBRZOG & $74-92$ & 0.02 & $(1.49)$ & 0.52 & $(3.15)$ & 0.00 & $(1.04)$ & -0.03 & $(0.54)$ & 0.03 & $(4.11)$ & 0.12 & 10 & 0.63 & 1.99 & 0.6 & 0.73 & 2.5 & 0.13 \\
\hline GBRZOO & $74-92$ & 0.01 & $\begin{array}{l}(0.45) \\
(1.32)\end{array}$ & -0.12 & $(0.43)$ & $\begin{array}{l}0.00 \\
-0.00\end{array}$ & $(0.08)$ & $\begin{array}{l}0.05 \\
0.00\end{array}$ & $(0.43)$ & 0.11 & $(0.71)$ & -0.19 & $(1.39)$ & $\begin{array}{r}-0.25 \\
0.03\end{array}$ & $\begin{array}{l}1.83 \\
1.54\end{array}$ & 0.6 & $\begin{array}{l}0.73 \\
0.35\end{array}$ & $\begin{array}{l}0.3 \\
0.8\end{array}$ & 0.92 \\
\hline $\begin{array}{l}\text { GBRZOP } \\
\text { GBRZOW }\end{array}$ & $74-92$ & $\begin{array}{l}0.02 \\
-0.00\end{array}$ & $\begin{array}{l}(1.32) \\
(0.27)\end{array}$ & 0.04 & $\begin{array}{l}(1.56) \\
(0.53)\end{array}$ & 0.00 & $(0.19)$ & 0.13 & $\begin{array}{l}(0.02) \\
(1.02)\end{array}$ & -0.08 & $(0.96)$ & $\begin{array}{l}0.44 \\
0.72\end{array}$ & $\begin{array}{r}(1.62) \\
(3.99)\end{array}$ & $\begin{array}{l}0.03 \\
0.46\end{array}$ & $\begin{array}{l}1.54 \\
2.27\end{array}$ & $\begin{array}{l}1.3 \\
1.0\end{array}$ & $\begin{array}{l}0.35 \\
0.48\end{array}$ & $\begin{array}{l}0.8 \\
1.1\end{array}$ & $\begin{array}{l}0.51 \\
0.47\end{array}$ \\
\hline & & & & & & & & & & & & & & & & & & & 0.41 \\
\hline
\end{tabular}

All definitions cf. appendix B1. If an entry cannot be calculated, it is denoted by $\star \star \star$. 
SECTOR SMPL

USAZ35 74-92

$\begin{array}{ll} & \\ \text { USAZLX } & 74-92\end{array}$

USAZMT $74-92$

USAZOO 74-92

USAZOW $74-92$

ESPZ35 $80-91$

$\begin{array}{lll}\text { ESP ZLF } & 80-91 & 0.01\end{array}$

$\begin{array}{lll}\text { ESP ZMB } & 80-91 & 0.01 \\ \text { ES-91 } & 0.01\end{array}$

$\begin{array}{ll}\text { ESPZMT } & 80-92 \\ \text { ESPZOG } & 80-91\end{array}$

ESPZOO

ESPZOP $80-91$

ITAZ35 $74-92$

$\begin{array}{ll}\text { ITAZ38 } & 74-92 \\ \text { ITAZLF } & 74-92\end{array}$

$\begin{array}{ll}\text { ITAZLX } & 74-92 \\ \text { ITAZMB } & 74-92\end{array}$

ITAZMT 74-92

$\begin{array}{ll}\text { ITAZOG } & 74-92 \\ \text { ITAZOO } & 74-92 \\ \text { ITAZOD } & 74-92\end{array}$

NLDZ35 74-92

NLDZ38 74-92

$\begin{array}{ll}\text { NLD ZLF } & 74-92 \\ \text { NLDZLX } & 74-92\end{array}$

NLDZMB 74-92

$\begin{array}{ll}\text { NLD ZMT } & 74-92 \\ \text { NLDZOG } & 74-92\end{array}$

$\begin{array}{ll}\text { NLDZOG } & 74-92 \\ \text { NLDZOP } & 74-92\end{array}$

$\begin{array}{lllll}0.01 & (1.41) & 0.10 & (0.83) & -0.00 \\ 0.00 & (0.37) & 0.10 & (0.87) & -0.00 \\ 0.01 & (1.99) & 0.01 & (0.19) & -0.00 \\ 0.01 & (2.33) & 0.06 & (1.81) & -0.00 \\ 0.01 & (0.91) & 0.04 & (0.58) & -0.00 \\ 0.01 & (1.46) & 0.09 & (1.08) & -0.00 \\ 0.00 & (0.28) & 0.02 & (0.58) & -0.00 \\ 0.01 & (0.99) & 0.05 & (1.47) & -0.00 \\ 0.01 & (1.67) & -0.02 & (0.63) & -0.00 \\ -0.00 & (0.20) & 0.04 & (1.82) & -0.00 \\ 0.00 & (0.46) & 0.07 & (1.28) & 0.00 \\ 0.00 & (0.12) & 0.07 & (2.31) & -0.00 \\ 0.01 & (1.60) & 0.05 & (1.39) & -0.00 \\ 0.01 & (0.58) & -0.04 & (1.27) & -0.00 \\ 0.01 & (0.78) & 0.02 & (0.77) & -0.00 \\ -0.01 & (0.67) & 0.13 & (1.68) & -0.00 \\ -0.01 & (0.70) & 0.09 & (0.96) & -0.00 \\ -0.00 & (0.10) & 0.02 & (1.46) & 0.00 \\ 0.02 & (1.51) & -0.00 & (0.07) & -0.00 \\ -0.01 & (0.52) & -0.00 & (0.09) & 0.00 \\ 0.01 & (1.72) & 0.04 & (0.58) & 0.00 \\ 0.03 & (3.37) & -0.19 & (2.03) & 0.00 \\ 0.02 & (2.47) & -0.02 & (0.46) & -0.00 \\ -0.00 & (0.15) & 0.00 & (0.53) & 0.00 \\ 0.00 & (0.21) & 0.05 & (1.76) & -0.01 \\ 0.02 & (2.40) & -0.06 & (0.83) & 0.00 \\ 0.01 & (2.45) & -0.01 & (0.79) & 0.00 \\ 0.02 & (2.29) & -0.01 & (0.83) & 0.01 \\ 0.01 & (2.00) & -0.00 & (0.03) & 0.00 \\ 0.01 & (2.54) & 0.05 & (0.55) & -0.00 \\ 0.02 & (3.23) & 0.05 & (1.28) & -0.00 \\ 0.01 & (0.58) & 0.00 & (0.00) & 0.00 \\ -0.01 & (0.58) & -0.02 & (0.47) & -0.00 \\ 0.00 & (0.09) & 0.18 & (4.10) & 0.00 \\ 0.01 & (3.20) & 0.06 & (1.03) & -0.00 \\ 0.01 & (2.04) & -0.02 & (0.48) & -0.00 \\ 0.02 & (3.35) & -0.00 & (0.24) & 0.00 \\ & & & & \\ & & & & \end{array}$

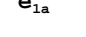

$\begin{array}{ll}(1.28) & -0.01 \\ (0.24) & -0.06\end{array}$

$\begin{array}{ll}(0.15) & 0.00 \\ (1.83) & 0.00\end{array}$

$\begin{array}{ll}(1.94) & 0.02 \\ (0.21) & -0.06\end{array}$

$\begin{array}{ll}(7.08) & -0.07 \\ (0.65) & -0.07\end{array}$

$\begin{array}{ll}(0.96) & -0.05 \\ (2.32) & -0.15\end{array}$

$(0.32)-0.14$

$\begin{array}{ll}(1.43) & -0.07\end{array}$

$\begin{array}{ll}(1.03) & 0.02 \\ (0.33) & 0.08\end{array}$

$\begin{array}{ll}(1.21) & -0.06 \\ (0.48) & 0.07\end{array}$

$\begin{array}{ll}(1.35) & -0.07 \\ (1.54) & 0.19\end{array}$

$(0.27) \quad-0.05$

$\begin{array}{ll}(1.04) & 0.03 \\ (3.89) & -0.10\end{array}$

$\begin{array}{ll}(1.98) & 0.02 \\ (0.34) & 0.07\end{array}$

$\begin{array}{ll}(0.41) & 0.12\end{array}$

$\begin{array}{ll}(0.84) & 0.11\end{array}$

$\begin{array}{ll}(0.81) & 0.09 \\ (0.91) & -0.02\end{array}$

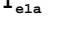

$(0.93)$ $-0.02$ $\begin{array}{ll}0.69) \quad 0.02 \\ (0.28) & 0.01\end{array}$ $\begin{array}{ll}(0.28) & -0.01 \\ (1.42) & 0.09\end{array}$ $\begin{array}{ll}(0.08) & 0.01 \\ (0.03) & -0.01\end{array}$

$\begin{array}{ll}1.25) & 0.06\end{array}$

$\begin{array}{ll}(1.62) & 0.05 \\ (4.39) & 0.30 \\ (1.32) & -0.22\end{array}$

$\begin{array}{ll}(1.06) & -0.02\end{array}$

$\begin{array}{ll}(0.59) & 0.06 \\ (2.03) & 0.16\end{array}$ $\left(\begin{array}{ll}(1.46) & 0.15\end{array}\right.$

$\begin{array}{ll}(0.80) & 0.08 \\ (0.13) & 0.18\end{array}$

$(0.78) \quad-0.04$

$\begin{array}{ll}(0.45) & 0.10 \\ (1.46) & -0.00\end{array}$

$\begin{array}{ll}(0.66) & 0.13 \\ (2.29) & -0.10\end{array}$

$\begin{array}{ll}(0.32) & 0.10\end{array}$

$\begin{array}{ll}(1.28) & 0.08 \\ (0.18) & -0.02\end{array}$

$\begin{array}{ll}(1.28) & -0.02 \\ (0.97) & -0.06\end{array}$

$\begin{array}{ll}(0.91) & -0.06\end{array}$

(1.61) 0.05

$\begin{array}{ll}(0.81) & -0.10 \\ (0.92) & -0.00\end{array}$

$\begin{array}{ll}(0.92) & -0.00 \\ (0.20) & -0.00\end{array}$
$\begin{array}{lllllllll}\mathbf{T}_{\mathrm{e1b}} & \mathbf{e}_{4} & \mathrm{~T}_{\mathrm{e} 4} & \overline{\boldsymbol{R}}^{2} & \text { DW } & \mathbf{F}_{81} & \mathbf{p}_{81} & \mathbf{F}_{85} & \mathbf{p}_{85}\end{array}$

$\begin{array}{llllllllll}(0.67) & 0.68 & \text { (3.87) } & 0.73 & 1.76 & * \star * & * \star * & 0.7 & 0.67\end{array}$

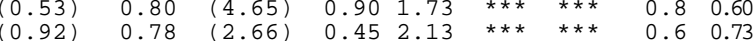
$\begin{array}{llllllllll}(1.38) & 1.19 & (14.55) & 0.95 & 1.35 & \star \star \star & \star \star \star & & 1.3 & 0.36 \\ (0.82) & 1.00 & (10.11) & 0.91 & 1.38 & \star \star \star & * \star * & 3.3 & 0.36\end{array}$ $\begin{array}{lllllllll}(0.11) & 0.97 & (5.74) & 0.90 & 2.04 & * * * & * * * & 1.7 & 0.25\end{array}$ $\begin{array}{llllllllll}(1.61) & 0.92 & (5.41) & 0.89 & 2.97 & * * * & * * * & 0.3 & 0.90\end{array}$ $\begin{array}{lllllllll}(0.22) & 0.90 & (6.12) & 0.81 & 1.95 & * * \star & * * * & 0.4 & 0.84\end{array}$

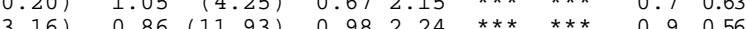
$\begin{array}{lllllllllllll}(1.69) & 0.96 & (6.22) & 0.79 & 2.31 & * * * & * * * & * * * & * * *\end{array}$

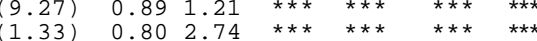

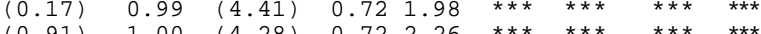
$(1.94) \quad 0.90 \quad(6.94) \quad 0.7331 .95 \quad * * * * * * \quad * * * * * *$ $\begin{array}{lllllllll}(1.59) & 0.64 & (3.13) & 0.83 & 1.87 & * * * & * \star * & * * * & * * *\end{array}$

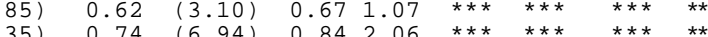

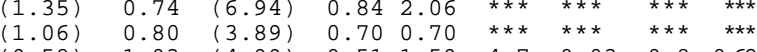
$\begin{array}{lllllllll}(1.25) & 0.97 & (6.25) & 0.51 & 1.59 & 4.7 & 0.03 & 0.8 & 0.62\end{array}$ $\begin{array}{lllllllll}(0.04) & 0.82 & (4.35) & 0.38 & 2.24 & 1.1 & 0.46 & 0.7 & 0.66\end{array}$ $\begin{array}{lllllllll}(1.68) & 0.54 & (1.84) & 0.35 & 2.27 & 3.1 & 0.08 & 0.1 & 0.99 \\ (1.64) & 0.63 & (1.85) & 0.73 & 2.59 & 0.7 & 0.67 & 0.5 & 0.78\end{array}$ $\begin{array}{lllllllll}(0.90) & 1.01 & (3.93) & 0.60 & 1.93 & 1.3 & 0.36 & 0.2 & 0.98 \\ (0.93) & 0.88 & (5.22) & 0.76 & 1.63 & 1.2 & 0.40 & 1.4 & 0.32\end{array}$

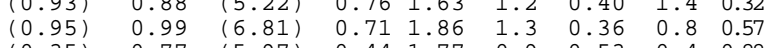
$\begin{array}{lllllllll}(0.63) & 0.88 & (4.67) & 0.37 & 1.39 & 1.9 & 0.22 & 1.3 & 0.36 \\ (1.63) & 0.44 & (1.48) & 0.69 & 1.44 & 1.6 & 0.27 & 0.7 & 0.36\end{array}$ $\begin{array}{lllllllll}(1.63) & 1.11 & (7.48) & 0.69 & 1.44 & 1.6 & 0.27 & 0.7 & 0.69 \\ (1.32) & 0.44 & (1.14) & 0.07 & 2.14 & 0.9 & 0.54 & 1.3 & 0.38\end{array}$ $\begin{array}{lllllllll}(1.32) & 0.44 & (1.14) & 0.07 & 2.14 & 0.9 & 0.54 & 1.3 & 0.38 \\ (0.95) & 0.68 & (7.00) & 0.72 & 1.57 & 0.2 & 0.96 & 2.9 & 0.10\end{array}$ $\begin{array}{llllllll}0.17 & (0.66) & 0.65 & 1.51 & 10.9 & 0.00 & 0.5 & 0.77\end{array}$ $\begin{array}{lllllllll}(1.50) & 0.77 & (4.09) & 0.55 & 1.17 & 2.0 & 0.19 & 0.9 & 0.57 \\ (0.04) & 0.98 & (8.26) & 0.73 & 1.55 & 0.6 & 0.73 & 7.4 & 0.01\end{array}$ $\begin{array}{lllllllll}(0.02) & 1.03 & (4.69) & 0.64 & 1.91 & 1.8 & 0.24 & 1.8 & 0.23\end{array}$ 
APPENDIX B6

Taking structural breaks into account

Labour growth determines wage growth

Regression equation identical to appendix B1. All other definitions according to appendix B1 and B5.

\begin{tabular}{|c|c|c|c|c|c|c|c|c|c|c|c|c|c|c|c|}
\hline SECTOR & SMPL & $e_{0}$ & $T_{e 0}$ & $e_{3}$ & $T_{e 3}$ & $e_{2}$ & $T_{\mathrm{e} 2}$ & $e_{1 a}$ & $\mathbf{T}_{\mathrm{ela}}$ & $e_{1 b}$ & $\mathbf{T}_{\mathrm{e} 1 \mathrm{~b}}$ & $e_{4}$ & $T_{e 4}$ & $\vec{R}^{2}$ & DW \\
\hline DEUZ35 & $74-92$ & 0.01 & $(2.74)$ & 0.08 & $(1.05)$ & 0.02 & $(1.48)$ & 0.05 & $(0.65)$ & 0.04 & $(0.40)$ & 0.79 & $(4.83)$ & 0.65 & 1.66 \\
\hline DEUZ38 8 & $\begin{array}{l}74-92 \\
77492\end{array}$ & 0.02 & $(2.66)$ & 0.03 & $(0.42)$ & 0.01 & 8) & 0.01 & $(0.16)$ & & $(0.69)$ & 0.96 & 41) & 0.64 & \\
\hline DEUZLF & $\begin{array}{l}74-92 \\
774-99\end{array}$ & 0.0 & $(1.2$ & 0.04 & $(1.60)$ & 0.00 & 10. & 0.13 & $(1.79)$ & -0.00 & $(0.14)$ & 14 & $(10.81)$ & 87 & .85 \\
\hline $\begin{array}{l}\text { DEUZLX } \\
\text { DEUZMB }\end{array}$ & $\begin{array}{l}74-92 \\
74-92\end{array}$ & $\begin{array}{l}0.01 \\
0.01\end{array}$ & $\begin{array}{l}(1.44) \\
(2.41)\end{array}$ & $\begin{array}{c}0.00 \\
-0.02\end{array}$ & $\begin{array}{l}(0.03) \\
(0.36)\end{array}$ & $\begin{array}{l}0.01 \\
0.02\end{array}$ & $(0.82)$ & 0.05 & $(0.51)$ & 0.06 & $(1.03)$ & 0.87 & $(8.34)$ & 84 & 54 \\
\hline DEUZMT & $\begin{array}{l}4-92 \\
74-92\end{array}$ & .01 & $\begin{array}{r}(2.41) \\
(2.08)\end{array}$ & -0.02 & $(0.36)$ & 0.02 & $(1.26)$ & $\begin{array}{l}0.07 \\
-0\end{array}$ & $\begin{array}{l}0.56) \\
0.74)\end{array}$ & 0.03 & $(0.32)$ & 1.11 & $(3.16)$ & 0.52 & .66 \\
\hline DEUZOG & $\begin{array}{l}74-92 \\
74\end{array}$ & 0.01 & $\begin{array}{r}(2.08) \\
(0.83)\end{array}$ & $\begin{array}{l}0.08 \\
0.03\end{array}$ & $\begin{array}{l}(1.54) \\
(1.45)\end{array}$ & $\begin{array}{l}0.0 \\
0.0\end{array}$ & $\begin{array}{l}(0.41) \\
(0.89)\end{array}$ & $\begin{array}{l}-0.08 \\
0.24\end{array}$ & $\begin{array}{l}(0.74) \\
(2.48)\end{array}$ & $\begin{array}{l}0.17 \\
-0.01\end{array}$ & $\begin{array}{l}(1.69) \\
(0.53)\end{array}$ & $\begin{array}{l}0.92 \\
0.87\end{array}$ & $\begin{array}{l}(7.25) \\
(4.96)\end{array}$ & $\begin{array}{l}0.79 \\
0.84\end{array}$ & $\begin{array}{l}1.47 \\
2.31\end{array}$ \\
\hline DEUZOO & $\begin{array}{l}74-92 \\
74-92\end{array}$ & .03 & $(1.95)$ & -0.00 & $(1.57)$ & -0.01 & $\begin{array}{l}(0.69) \\
(0.26)\end{array}$ & $\begin{array}{l}0.24 \\
0.12\end{array}$ & $(1.06)$ & -0.01 & $(0.27)$ & 0.88 & $\begin{array}{l}(3.51) \\
(3.51)\end{array}$ & $\begin{array}{l}0.049 \\
0.59\end{array}$ & 2.01 \\
\hline DEUZOP & $74-92$ & .01 & $(2.27)$ & -0.00 & $(0.03)$ & 0.02 & $(1.07)$ & 0.37 & $(4.06)$ & -0.22 & $(3.02)$ & 0.60 & $(3.62)$ & 0.78 & 1.01 \\
\hline DEUZOW & 70 & 01 & (1.58) & 0.00 & $(0.13)$ & 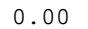 & $(0.45)$ & -0.02 & $(0.22)$ & 0.13 & $(1.80)$ & 0.99 & $(8.54)$ & 0.85 & 2.62 \\
\hline FRAZ35 & $\begin{array}{l}74-91 \\
74\end{array}$ & 01 & (1.50) & -0.19 & $\begin{array}{l}(1.52) \\
\text { (1) }\end{array}$ & 0.00 & $(3.14)$ & 0.11 & 3) & 0.11 & . .33$)$ & 0.74 & $\begin{array}{l}(0.04) \\
(1.75)\end{array}$ & 0.70 & 1.61 \\
\hline FRAZ38 & 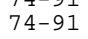 & 01 & $(0.94)$ & 0.11 & $(1.02)$ & 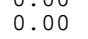 & $(1.10)$ & 0.04 & & & . .97$)$ & 1.14 & $\begin{array}{l}(4.77) \\
\text { (1) }\end{array}$ & 0.53 & \\
\hline FRAZLF & & & & 0.02 & & & 1) & 0 . & & & & -0.36 & $(0.41)$ & -0.22 & 0.77 \\
\hline FRAZLX & 74 & 03 & i & 0.02 & & 0.0 & $(0.59)$ & -0.04 & & 0. & $(0.26)$ & 1.24 & $(2.33)$ & 0.17 & 1.23 \\
\hline FRAZMB & & .01 & & & 1) & & 8) & & & & $(0.44)$ & 0.78 & $(0.81)$ & 0.12 & 2.75 \\
\hline FRAZMT & $74-91$ & .01 & $(1.66)$ & 0.02 & $.14)$ & .00 & $(2.67)$ & -0.06 & 67) & 0.19 & $(3.64)$ & 1.08 & $(5.29)$ & 0.75 & 1.35 \\
\hline FRAZOG & $74-91$ & & & -0.05 & & 0.00 & 1) & 0.26 & 51) & -0.03 & $(0.30)$ & 0.63 & $(2.47)$ & 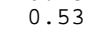 & \\
\hline FRAZOO & $74-91$ & 00 & $(0.12)$ & 0.01 & $(0.48)$ & & & & & & $(0.46)$ & 0.32 & $(0.32)$ & -0 & 1.95 \\
\hline FRAZOP & $74-91$ & 02 & $(5.68)$ & -0.16 & $(3.96)$ & -0.00 & $(2.01)$ & -0.05 & $(1.54)$ & 0. & $(2.77)$ & -0.01 & 2) & 0.86 & 2.53 \\
\hline FRAZOW & $74-91$ & 01 & $(0.51)$ & 0.01 & & & $(1.26)$ & -0.20 & & & $(1.91)$ & 0.51 & $(2.02)$ & 0.22 & 1.68 \\
\hline GBRZ35 & $86-$ & 02 & 10. & 0.18 & & .03 & 9) & 0.27 & & -0.15 & & -1.26 & $(1.01)$ & 0.38 & 1.83 \\
\hline GBRZ38 & $74-$ & 0.01 & (C & 11 & & & (0 & 0. & & 0.02 & 10 & 0.29 & $(1.12)$ & 0.10 & 1.93 \\
\hline GBRZ & & .02 & & & & & & & & & & & & & 1.95 \\
\hline GBRZLX & 8 & 0.1 & 75) & & & -0 & (7) & -0.12 & & & 83) & 0.19 & & 1.00 & 1.31 \\
\hline GBRZMB & $74-$ & 0. & $(0.44)$ & & & 0. & (1. & 0 . & & & & & $(0.94)$ & -0.20 & 1.28 \\
\hline GBRZMT & $86-$ & -0.01 & (2. & & & & & & & & & & & 0.99 & 3.24 \\
\hline GBR & $74-$ & 0.0 & & 0. & & & & & & & & & & 0.63 & 1.99 \\
\hline GBRZOO & 74-92 & 0. & $(0.2$ & -0.12 & & & 8) & 0.0 & & & & 0.19 & $(1.39)$ & -0.25 & 1.83 \\
\hline GBRZOP & $74-92$ & 0.02 & $(1.32)$ & 0.09 & $(1$. & -0.00 & $(0.77)$ & 0 . & (0. & & & 0.44 & $(1.62)$ & 0.03 & 1.54 \\
\hline GBRZOW & 74-92 & -0.00 & $(0.27)$ & 0.04 & $(0.53)$ & 0.00 & $(0.19)$ & 0.1 & $(1.02)$ & -0.08 & $(0.96)$ & 0.72 & $(3.99)$ & 0.46 & 2.27 \\
\hline USAZ35 & $74-92$ & 0.01 & $(1.41)$ & 0.10 & $(0.83)$ & -0.00 & $(0.41)$ & 0.0 & $(0.93)$ & -0.02 & 10. & 0.68 & $(3.87)$ & 0.73 & .76 \\
\hline USAZ38 & $74-92$ & 0.0 & $(0.37)$ & 0.1 & $(0.87)$ & -0.00 & $(0.18)$ & -0.01 & 10. & 0. & $(0$ & 0.80 & $(4.65)$ & 0.90 & 1.73 \\
\hline & $74-$ & 0.0 & $(1.99$ & 0.0 & $(0.19)$ & -0.00 & $(2.00)$ & 0.01 & $(0.30)$ & 0. & $(0.92)$ & 0.78 & $(2.66)$ & 0.45 & .13 \\
\hline USAZLX & $\begin{array}{l}74-92 \\
86-92\end{array}$ & $\begin{array}{l}0.01 \\
-0\end{array}$ & $(2.33)$ & $\begin{array}{l}0.06 \\
-0.17\end{array}$ & $(1.81)$ & & $(2.43)$ & 0.00 & (0. & -0.04 & $(1.38)$ & 1.19 & $(14.55)$ & .95 & 1.35 \\
\hline USAZMB & $86-92$ & -0.01 & $(1.07)$ & -0.17 & $(3.46)$ & -0.12 & $(1.69)$ & 0.17 & $(1.64)$ & -0.16 & $1.31)$ & 1.01 & $(2.67)$ & 0.93 & 3.01 \\
\hline $\begin{array}{l}\text { USAZMT } \\
\text { USAZOG }\end{array}$ & $\begin{array}{l}74-9 \\
74-9\end{array}$ & $\begin{array}{l}0.0 \\
0.0\end{array}$ & $\begin{array}{l}(1.46) \\
(0.28)\end{array}$ & $\begin{array}{l}0.0 \\
0.0\end{array}$ & $\begin{array}{l}(1.08) \\
(0.58)\end{array}$ & $\begin{array}{l}-0.00 \\
-0.00\end{array}$ & $\begin{array}{l}(1.28) \\
(0.24)\end{array}$ & $\begin{array}{l}-0.01 \\
-0.06\end{array}$ & $\begin{array}{l}(0.28) \\
(1.42)\end{array}$ & $\begin{array}{l}-0.01 \\
0.09\end{array}$ & $\begin{array}{l}(0.11) \\
(1.61)\end{array}$ & $\begin{array}{l}0.97 \\
0.92\end{array}$ & $\begin{array}{l}(5.74) \\
(5.41)\end{array}$ & $\begin{array}{l}0.90 \\
0.89\end{array}$ & $\begin{array}{l}2.04 \\
2.97\end{array}$ \\
\hline USAZOO & $74-92$ & 0.01 & $(0.99)$ & 0.05 & $(1.47)$ & -0.00 & $(0.15)$ & 0.00 & $(0.08)$ & 0.01 & $(0.22)$ & 0.90 & $(6.12)$ & 0.81 & 1.95 \\
\hline
\end{tabular}




\begin{tabular}{|c|c|c|c|c|c|c|c|c|c|c|c|c|c|c|c|}
\hline SECTOR & SMPL & $e_{0}$ & $\mathbf{T}_{\mathrm{eo}}$ & $e_{3}$ & $\mathbf{T}_{\mathbf{e} 3}$ & $e_{2}$ & $T_{\mathrm{e} 2}$ & $e_{1 a}$ & $\mathbf{T}_{\mathrm{e1a}}$ & $e_{1 b}$ & $\mathbf{T}_{\mathbf{e} 1 \mathrm{~b}}$ & $\mathbf{e}_{4}$ & $T_{e 4}$ & $\bar{R}^{2}$ & DW \\
\hline ISAZOP & 74-92 & 0.01 & $(1.67)$ & -0.02 & $(0.63)$ & -0.00 & $(1.83)$ & 0.00 & $(0.03)$ & -0.01 & $(0.20)$ & 1.05 & $(4.25)$ & 0.67 & 2.15 \\
\hline BAZOW & 7 & -0.00 & . 20) & 0.04 & $(1.82)$ & -0.00 & $(1.94)$ & 00 & $(1.25)$ & 0.06 & $(3.16)$ & 0.86 & $(11.93)$ & 0.98 & 2.2 \\
\hline ESPZ35 & 8 & 0.00 & ) & 0.07 & 3) & 0.00 & 0. & -0.06 & (0. & 0.05 & (1. & 0.96 & $(6.22)$ & 0.79 & 2.3 \\
\hline ESPZ38 & 8 & 0.00 & ) & 0.0 & 1) & -0.00 & (4. & -0.44 & $(4$. & 0.30 & (3 & 0.94 & $(9.27)$ & 0.89 & 27 \\
\hline SPZLF & 8 & 0.01 & ) & 0. & 9) & -0 & $(7$ & -0 & (1. & -0.22 & 4) & 0.25 & $(1.33)$ & 0.80 & 7. \\
\hline ESPZLX & 8 & 0.01 & ) & -0.04 & (1. & -0 & 10. & -0 & $(1.06)$ & -0.02 & & 0.99 & $(4.41)$ & 0.72 & 98 \\
\hline ESP ZMB & 8 & 0.01 & 3) & 0.02 & $(0,77)$ & -0 & & -0 & 10. & 0.06 & $(0.91)$ & 1.00 & $(4.28)$ & 0.72 & \\
\hline ESPZMT & $80-$ & -0.01 & ) & 0.1 & (1. & -0 & $(2$ & -0 & (2. & 0.16 & $(1.94)$ & & $(6.94)$ & 0.73 & \\
\hline ESPZOG & $80-$ & -0.01 & 10. & 0.0 & 10. & -0.00 & 10. & -0.14 & $(1.46)$ & 0. & & 0.64 & $(3.13)$ & 0.83 & .8 \\
\hline ESPZOO & $80-91$ & -0.00 & $(0.10)$ & 0.02 & $(1.46)$ & 0.00 & $(0.03)$ & -0.17 & $(1.54)$ & 0.11 & $(0.85)$ & 0.62 & $(3.10)$ & 0.67 & $1.0^{\circ}$ \\
\hline $\begin{array}{l}\text { ESPZOP } \\
\text { ESPZOW }\end{array}$ & $\begin{array}{l}80-91 \\
80-91\end{array}$ & $\begin{array}{c}0.02 \\
-0.01\end{array}$ & $\begin{array}{l}(1.51) \\
(0.52)\end{array}$ & $\begin{array}{l}-0.00 \\
-0.00\end{array}$ & $\begin{array}{l}(0.07) \\
(0.09)\end{array}$ & $\begin{array}{l}-0.00 \\
0.00\end{array}$ & $\begin{array}{l}(1.43) \\
(1.03)\end{array}$ & $\begin{array}{l}-0.07 \\
0.02\end{array}$ & $\begin{array}{l}(0.80) \\
(0.13)\end{array}$ & $\begin{array}{l}0.08 \\
0.18\end{array}$ & $\begin{array}{l}(1.35) \\
(1.06)\end{array}$ & $\begin{array}{l}0.74 \\
0.80\end{array}$ & $\begin{array}{r}(6.94) \\
(3.899)\end{array}$ & $\begin{array}{l}0.84 \\
0.70\end{array}$ & 2.0 \\
\hline ITAZ35 & $81-$ & $\overline{0}$ & $(2.5$ & $\begin{array}{l}-0.00 \\
-0.01\end{array}$ & 10. & 0.0 & (1. & 0. & 10. & $\begin{array}{l}. .18 \\
-0.01\end{array}$ & $\begin{array}{l}(1.06) \\
(0.10)\end{array}$ & & $\begin{array}{r}(3.89) \\
(3.35)\end{array}$ & $\begin{array}{l}0.70 \\
0.70\end{array}$ & $\begin{array}{l}0.76 \\
1.88\end{array}$ \\
\hline & $81-$ & & ( & -0 . & 1. & -0 & & -8 & 10. & 0.13 & & & $(6.18)$ & 0.83 & \\
\hline & 7 & & ) & -0.02 & b. & -0 & & & (1. & & & & (4. & 0.38 & \\
\hline ITAZLX & $74-$ & .00 & & 0.0 & B) & 0 & & & ic & & & & $(1.84)$ & 0.35 & \\
\hline B & & & & & & & & & & & & & $5)$ & 0.73 & $z$ \\
\hline ITA & & & & & & & & & & & & 1.01 & 3) & 0. & \\
\hline & & & & & & & & & & & & 0.88 & & & 9 \\
\hline & & & & & & & & & & & & & 1) & & 1.6 \\
\hline ITAZ & 74 & & & -0.00 & & 0. & & 0. & & & & 0.77 & $(5.97)$ & & 1.86 \\
\hline NLDZ35 & $74-$ & & & 0.0 & 10. & -0 . & 10. & 0. & (1. & & & 0. & (4. & +7 & $\begin{array}{r}1 \\
38\end{array}$ \\
\hline NLDZ38 & $74-$ & & & 0. & (1. & -0 & $(3.38)$ & -0.08 & (0. & & $(1.63)$ & 1.11 & $(7.48$ & (3) & 1.35 \\
\hline NLDZLF & $74-$ & 0 & 10. & 0.0 & (0. & 0. & (0. & 0. & & & $(1.32)$ & & & & $\begin{array}{l}1.44 \\
2.12\end{array}$ \\
\hline NLDZLX & $74-$ & -0 & & -0 . & & & & & & & & & & & $\begin{array}{l}2.12 \\
1.5\end{array}$ \\
\hline NLD & 81 & -0 . & (3. & 0. & (12. & & & & & & & & & & $\begin{array}{l}1.2 \\
2.2\end{array}$ \\
\hline NLD ZMT & $74-$ & 0. & (3. & 0. & $(1.03$ & -0.00 & 10. & 0 & (0. & & & & & & \\
\hline NLD & 86 & 0. & & & & & & & & & & & & & \\
\hline & $74-92$ & 0.0 & $(3.35)$ & -0.00 & $0.24)$ & & $.91)$ & -0.02 & & 0. & & 1.0 & 4.69 & 0.6 & 1.91 \\
\hline
\end{tabular}

Wage growth determines labour growth - final regressions

Regression equation is:

$$
\begin{aligned}
& L_{i j t}=g_{0 i j}+g_{1 a i j} M_{e u i j t}+g_{1 b i j} M_{\text {neuijt }}+g_{2 i j} r_{i j t}+g_{3 i j} A_{i j t}+g_{4 i j} W_{i j t}+\pi_{i j t} \\
& \text { where, } i=\text { sector; } \\
& { }_{W}, M_{\text {eu }}, M_{\text {neu }}, r, A, L \text { are defined cf. the imperfect competition model; }
\end{aligned}
$$

SECTOR SMPL

ESPZTX $80-910-0.03$

GBRZ35 $\quad 74-92 \quad-0.03$

$\begin{array}{lll}\text { GBRZLX } & 86-92 & -0.53 \\ \text { GBRZMB } & 74-89 & -0.09\end{array}$
$\mathbf{T}_{\mathrm{eo}} \quad \mathbf{e}_{3}$

$\begin{array}{lll}-0.03 & (1.44)-0.03 \\ -0.03 & (2.87)-0.03\end{array}$

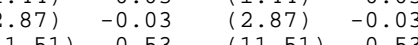

$\begin{array}{llll}(11.51) & -0.53 & (11.51) & -0.53 \\ (3.28) & -0.09 & (3.28) & -0.09\end{array}$ $\begin{array}{ll}1.44) & -0.03 \\ 2.87) & -0.03\end{array}$

$\begin{array}{ll}(1.87) & -0.03 \\ (3.28) & -0.53 \\ (3) & -0.09\end{array}$
$\begin{array}{llllll}\mathbf{T}_{\mathrm{elb}} & \mathbf{e}_{4} & \mathbf{T}_{\mathrm{e} 4} & \bar{R}^{2} & \text { DW }\end{array}$

$\begin{array}{lllll}(1.44) & -0.03 & (1.44) & 0.87 & 2.09\end{array}$ $\begin{array}{lllll}(1.44) & -0.03 & (1.44) & 0.87 & 2.09 \\ (1.87) & -0.03 & (2.87) & 0.42 & 1.81\end{array}$ $\begin{array}{lllll}(11.51) & -0.53 & (11.51) & 1.00 & 1.25 \\ (3.28) & -0.09 & (3.28) & 0.34 & 2.17\end{array}$ 


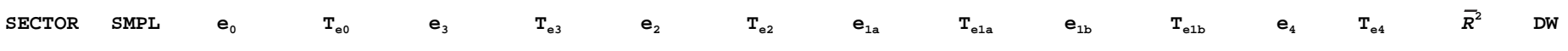

$\begin{array}{lllllllllllllllll}\text { ITAZOP } & 81-92 & -0.01 & (2.91) & -0.01 & (2.91) & -0.01 & (2.91) & -0.01 & (2.91) & -0.01 & (2.91) & -0.01 & (2.91) & 0.82 & 1.62\end{array}$ 
APPENDIX B7

Solutions to the system of equations

The equations from which these solutions follow are given on p. 5. Values for the coefficients $e_{0-4}$ are taken from appendix B6.

\begin{tabular}{|c|c|c|c|c|c|c|c|c|}
\hline SECTOR & SMPL & $\frac{\phi(\beta-\theta)}{1-\alpha-\beta}$ & $\delta$ & $\hat{B}$ & $\varepsilon$ & $\alpha(\phi+1)$ & $\beta(\phi+1)$ & $\begin{array}{l}\alpha(\phi+1) \\
\beta\left(\phi_{+}^{+} 1\right)\end{array}$ \\
\hline USAZOW & $74-92$ & 0.53 & 0.12 & -0.88 & 0.55 & 0.96 & 0.90 & 1.87 \\
\hline USAZOP & 74-92 & 1.20 & 1.94 & 2.09 & -0.57 & 0.89 & 0.43 & 1.32 \\
\hline USAZOO & 74-92 & 1.46 & 0.95 & 1.39 & 0.13 & 0.89 & 2.72 & 3.61 \\
\hline USAZOG & 74-92 & 1.80 & -1.69 & 0.18 & 2.01 & 0.91 & 2.18 & 3.10 \\
\hline USAZMT & 74-92 & 0.49 & -0.68 & 2.37 & -2.38 & 0.88 & 3.27 & 4.14 \\
\hline USAZMB & $86-92$ & 1.75 & 0.70 & -5.36 & -0.98 & 0.81 & 0.71 & 1.52 \\
\hline USAZLX & 74-92 & -0.96 & 0.82 & 0.13 & -1.45 & 0.89 & 0.45 & 1.34 \\
\hline USAZLF & 74-92 & 0.28 & 2.28 & 1.70 & 0.75 & 0.87 & 2.67 & 3.54 \\
\hline USAZ38 & $74-92$ & -0.16 & -0.29 & 0.35 & 0.64 & 0.95 & 1.20 & 2.14 \\
\hline $\begin{array}{l}\text { USAZ355 } \\
\text { NDZOP }\end{array}$ & $\begin{array}{l}74-92 \\
74-92\end{array}$ & -0.36 & $\begin{array}{l}0.66 \\
-5\end{array}$ & 1.12 & -0.41 & 0.94 & $\begin{array}{l}1.17 \\
3.29\end{array}$ & 2.11 \\
\hline $\begin{array}{l}\text { NLDZMT } \\
\text { ND }\end{array}$ & $\begin{array}{l}4-92 \\
86-92\end{array}$ & $\begin{array}{l}15.19 \\
0.60\end{array}$ & $\begin{array}{l}-5.77 \\
0.58\end{array}$ & $\begin{array}{l}2.08 \\
-0.37\end{array}$ & $\begin{array}{l}-6.01 \\
-0.50\end{array}$ & $\begin{array}{l}0.13 \\
1.07\end{array}$ & $\begin{array}{l}3.29 \\
0.41\end{array}$ & $\begin{array}{l}3.43 \\
1.48\end{array}$ \\
\hline ¿DZMT & $74-$ & 0.25 & 0.09 & 0.0 & -0.18 & 0.95 & 0.99 & $\begin{array}{l}1.48 \\
1.94\end{array}$ \\
\hline ILDZMB & $81-92$ & 1.33 & -0.68 & 1.08 & 0.35 & $\begin{array}{l}1.04 \\
1.04\end{array}$ & $\begin{array}{l}1.17 \\
1.17\end{array}$ & $\begin{array}{l}1.94 \\
2.22\end{array}$ \\
\hline LDZLX & $74-92$ & 2.05 & 0.18 & -1.48 & 1.2 & 0.92 & 1.4 & 2. \\
\hline DZLF & 74 & -0.46 & -2 . & -1.40 & 2.0 & 1.11 & -1.27 & -0.17 \\
\hline LDZ38 & $14-$ & -0.64 & -2.09 & 0.32 & -1.75 & 0.91 & 0.36 & 1.27 \\
\hline DZ35 & & $8 \varepsilon$ & 1.1 & & -0 & 0.93 & 1.7 & \\
\hline TAZ & 74 & -3.22 & 1.82 & -0.13 & -1.17 & 1.0 & -1.68 & -0.62 \\
\hline ITAZOG & 74-92 & 129.23 & 15.01 & 0.20 & 39.8 & -1.56 & 61.13 & 59.56 \\
\hline TA7MT & 74-92 & -3.07 & & 0.49 & -0.24 & 1.13 & -0.50 & 0.63 \\
\hline ITAZMB & $74-92$ & 0.25 & 0.16 & 0.05 & -0.15 & 0.96 & 0.67 & 1.63 \\
\hline ITAZLX & 74-92 & -1.62 & 3.90 & 4 & -0.45 & 1.18 & -2.69 & -1.50 \\
\hline ITAZ & 74-92 & 1.29 & 0.79 & 0. & -0.30 & 0.96 & 1.00 & 1.95 \\
\hline ITAZ & 81-92 & 2.64 & -1.27 & 0.39 & 0.23 & 0.91 & 2.26 & 3.17 \\
\hline ITAZ35 & 81-92 & -1.93 & -1.47 & -0.15 & 1.24 & 1.06 & -1.61 & -0.54 \\
\hline GBRZOW & 74-92 & -0.82 & -0.21 & 0.94 & 2.1 & 1.09 & -1.67 & -0.58 \\
\hline GBRZOP & 74-92 & -0.87 & 0.3 & & 0.6 & 0.9 & 0.93 & 1.85 \\
\hline GBRZOO & 74-92 & 0.11 & -1.25 & & -0.22 & 1.1 & 0.57 & 1.68 \\
\hline GBRZOG & 74-92 & 3.92 & 3.5 & -1.00 & -2.19 & 1.39 & -1.29 & 0.11 \\
\hline GBRZMT & $86-92$ & -6.88 & -2.10 & & -1.10 & 1.14 & -2.98 & -1.84 \\
\hline GBRZLF & $81-92$ & 2.55 & 2.2 & 0.42 & -0.52 & 0.87 & 2.99 & 3.86 \\
\hline GBRZ38 & 74-92 & -35.11 & -6.33 & 72.81 & -11.00 & 3.75 & -22.07 & -18.32 \\
\hline FRAZOW & 74-91 & -1.13 & 0.5 & -2.04 & -0.22 & 1.09 & -1.24 & -0.15 \\
\hline FRAZOP & $74-91$ & -1.74 & -2.03 & 0.41 & 0.28 & 0.87 & -2.43 & -1.56 \\
\hline FRAZOO & 74-91 & -0.86 & 3.30 & -0.45 & -1.07 & 1.13 & -1.10 & 0.03 \\
\hline $\begin{array}{l}\text { FRAZOG } \\
\text { FRAZMM }\end{array}$ & $74-91$ & 1.77 & 0.34 & 0.53 & -0.57 & 0.95 & 0.94 & 1.88 \\
\hline $\begin{array}{l}\text { FRAZMT } \\
\text { FRA ZMB }\end{array}$ & $\begin{array}{l}74-91 \\
74-91\end{array}$ & -0.14 & 2.21 & -2.62 & -0.52 & $\begin{array}{l}1.12 \\
1.53\end{array}$ & -0.48 & 0.64 \\
\hline RAZMB & $\begin{array}{l}74-91 \\
74-91\end{array}$ & -2.18 & $\begin{array}{l}5.28 \\
-30\end{array}$ & $\begin{array}{r}15.03 \\
13.25\end{array}$ & -3.80 & $\begin{array}{l}1.53 \\
-1.40\end{array}$ & -11.09 & -9.57 \\
\hline FRAZLF & $74-91$ & -18.68 & $\begin{array}{l}-30.39 \\
5.95\end{array}$ & 18.34 & $\begin{array}{l}10.41 \\
-205\end{array}$ & -0.36 & -1324 & 50 \\
\hline & & & & & & & & -13.59 \\
\hline
\end{tabular}




$\begin{array}{lllllllll}\text { SECTOR } & \text { SMPL } & \frac{\phi(\beta-\theta)}{1-\alpha-\beta} & \delta & \hat{\boldsymbol{B}} & \varepsilon & \alpha(\boldsymbol{\phi} \mathbf{1}) & \beta(\boldsymbol{\phi}+\mathbf{1}) & \begin{array}{l}\alpha(\boldsymbol{\phi}+\mathbf{1}) \\ \beta(\boldsymbol{\phi}+\mathbf{1})\end{array} \\ & & & & & & & & \\ \text { FRAZ38 } & 74-91 & 2.03 & -1.90 & -0.32 & -3.75 & 1.19 & -0.84 & 0.35 \\ \text { FRAZ35 } & 74-91 & -5.42 & -0.42 & -0.22 & -0.41 & 1.21 & -4.17 & -2.96 \\ \text { ESPZOW } & 80-91 & -7.55 & -0.95 & 7.18 & -1.05 & 1.26 & -5.74 & -4.48 \\ \text { ESPZOP } & 80-91 & 3.46 & -2.58 & 0.31 & 2.52 & 0.88 & 2.48 & 3.36 \\ \text { ESPZOO } & 80-91 & 4.05 & -1.71 & -2.44 & 0.57 & 0.70 & 5.17 & 5.87 \\ \text { ESPZOG } & 80-91 & -0.13 & -0.17 & -0.19 & 0.11 & 0.97 & 0.59 & 1.55 \\ \text { ESPZMT } & 80-92 & 1.70 & -0.39 & -1.79 & 0.25 & 0.92 & 1.88 & 2.81 \\ \text { ESPZMB } & 80-91 & 2.72 & -1.71 & 2.18 & 1.64 & 0.88 & 3.18 & 4.06 \\ \text { ESPZLF } & 80-91 & -0.18 & -0.71 & 0.04 & -0.23 & 0.97 & 0.22 & 1.18 \\ \text { ESPZ38 } & 80-91 & 1.10 & -1.93 & 1.65 & 1.07 & 0.85 & 3.81 & 4.66 \\ \text { ESPZ35 } & 80-91 & -6.74 & 14.38 & -8.24 & -9.25 & 1.84 & -21.99 & -20.14 \\ \text { DEUZOW } & 74-92 & -3.77 & 1.14 & -2.95 & -0.38 & 1.14 & -3.88 & -2.73 \\ \text { DEUZOP } & 74-92 & -18.41 & -5.34 & -10.20 & 4.23 & 1.59 & -9.78 & -8.18 \\ \text { DEUZOO } & 74-92 & 2.00 & 0.12 & 0.26 & -0.26 & 0.95 & 1.29 & 2.24 \\ \text { DEUZOG } & 74-92 & -0.94 & -0.32 & -0.73 & 0.33 & 1.06 & -1.36 & -0.30 \\ \text { DEUZMT } & 74-92 & -1.01 & 3.78 & -0.15 & -0.58 & 1.16 & -3.98 & -2.82 \\ \text { DEUZMB } & 74-92 & -7.70 & -9.80 & -1.14 & -2.99 & 1.61 & -2.45 & -0.84 \\ \text { DEUZLX } & 74-92 & -1.68 & -0.82 & -0.06 & -1.10 & 1.07 & -1.75 & -0.67 \\ \text { DEUZLF } & 74-92 & 0.44 & -0.31 & -1.97 & 0.86 & 1.13 & -0.52 & 0.60 \\ \text { DEUZ38 } & 74-92 & -1.22 & -0.09 & -0.16 & -0.68 & 1.06 & -1.60 & -0.54 \\ \text { DEUZ35 } & 74-92 & -0.57 & -4.84 & -0.60 & -3.13 & 1.40 & -8.60 & -7.20\end{array}$

Wage growth determines labour growth - solutions to the system of equations

$\begin{array}{lllllllll}\text { SECTOR } & \text { SMPL } & \frac{\phi(\beta-\theta)}{1-\alpha-\beta} & \delta & \hat{\boldsymbol{B}} & \varepsilon & \alpha(\phi+1) & \beta(\phi+1) & \begin{array}{l}\alpha(\phi+1) \\ \beta(\phi+1)\end{array} \\ & & & & & & & & \\ \text { GBRZ35 } & 74-92 & -2.17 & -2.80 & 5.08 & -0.63 & 4.26 & -3.77 & 0.49 \\ \text { GBRZMB } & 74-89 & 0.65 & -0.53 & -0.79 & 0.12 & 0.82 & 0.20 & 1.03 \\ \text { ESPZLX } & 80-91 & 1.62 & 1.97 & -0.87 & 0.85 & -0.94 & 2.03 & 1.10 \\ \text { ITAZOP } & 81-92 & 0.61 & -0.54 & -0.15 & -0.40 & 0.41 & 0.62 & 1.03 \\ \text { GBRZLX } & 86-92 & -5.09 & -2.00 & 1.89 & 0.36 & 2.70 & -1.83 & 0.88\end{array}$

